\title{
ॠUSGS
}

science for a changing world

Prepared in cooperation with the

MUNICIPIO AUTÓNOMO DE PONCE, PUERTO RICO

OFFICE OF THE MAYOR

Hydrologic, Water-Quality, and Biological Assessment of Laguna de Las Salinas, Ponce, Puerto Rico, January 2003-September 2004

U,S. Geologjical Survey , at

Scjentific Investigatioss 3 Ricport 2005-5: 54

Trix

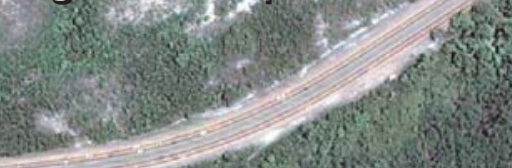




\section{Hydrologic, Water-Quality, and Biological Assessment of Laguna de Las Salinas, Ponce, Puerto Rico, January 2003-September 2004}

By Luis R. Soler-López, Fernando Gómez-Gómez, and Jesús Rodríguez-Martínez 


\title{
U.S. Department of the Interior Gale A. Norton, Secretary
}

\author{
U.S. Geological Survey \\ P. Patrick Leahy, Acting Director
}

\section{U.S. Geological Survey, Reston, Virginia: 2005}

For sale by U.S. Geological Survey, Information Services Box 25286, Denver Federal Center

Denver, CO 80225

For more information about the USGS and its products:

Telephone: 1-888-ASK-USGS

World Wide Web: http://www.usgs.gov/

Any use of trade, product, or firm names in this publication is for descriptive purposes only and does not imply endorsement by the U.S. Government.

Although this report is in the public domain, permission must be secured from the individual copyright owners to reproduce any copyrighted materials contained within this report.

Suggested citation:

Soler-López, Luis, Gómez-Gómez, Fernando, and Rodríguez-Martínez, Jesús, 2005, Hydrologic, water-quality, and biological assessment of Laguna de Las Salinas, Ponce, Puerto Rico, January 2003-September 2004: U.S.

Geological Survey Scientific Investigations Report 2005-5154, 50 p. 


\section{Contents}

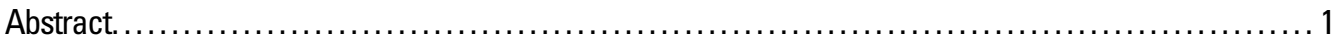

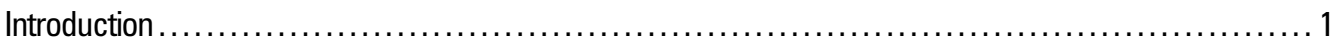

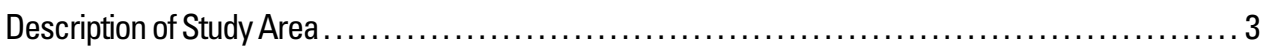

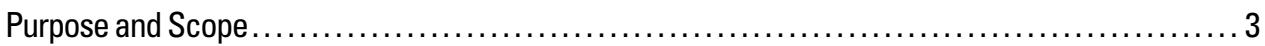

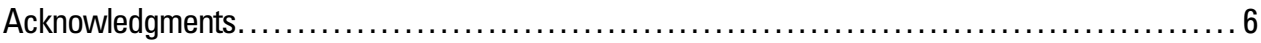

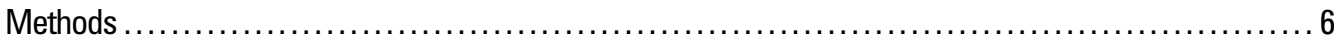

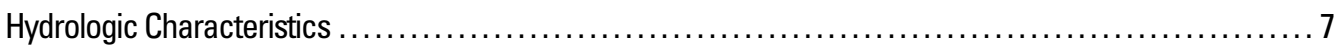

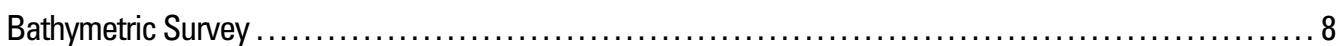

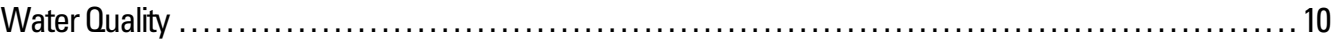

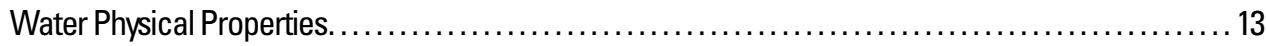

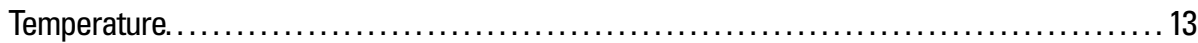

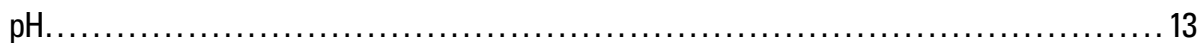

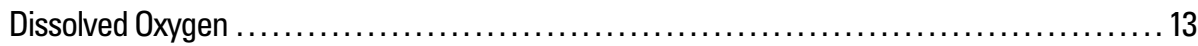

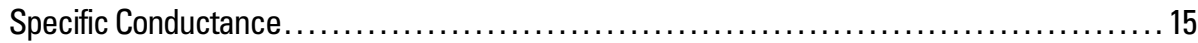

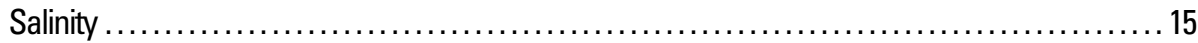

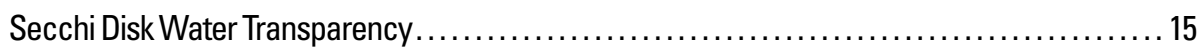

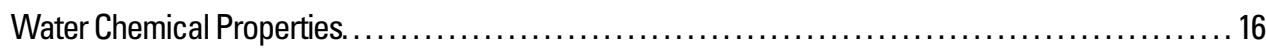

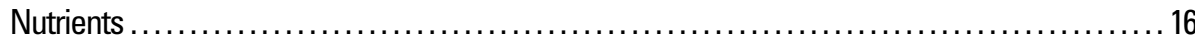

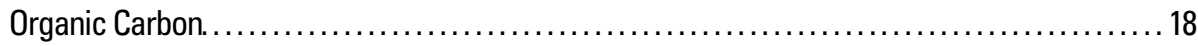

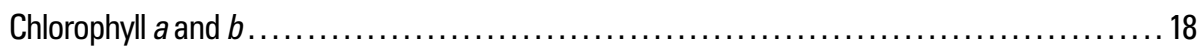

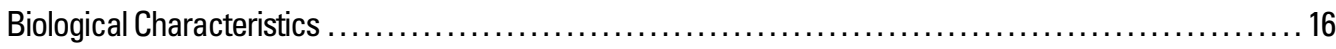

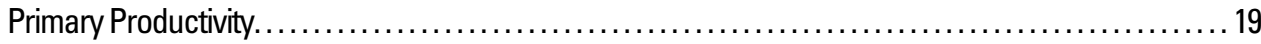

Light and Dark Bottle Primary Productivity, Community Respiration, and Community Gross

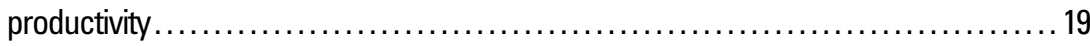

Diel Primary Productivity, Community Respiration, and Community Gross Productivity. . . . . . . 20

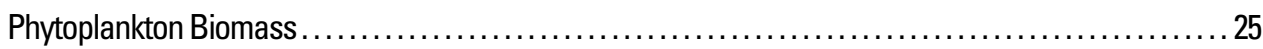

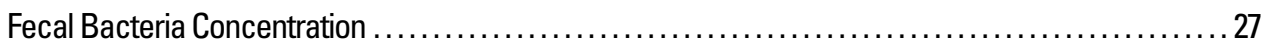

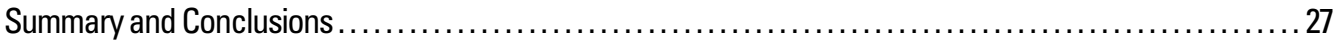

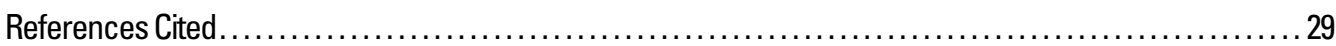

Appendix 1. On-site determination of $\mathrm{pH}$, temperature, specific conductance, dissolved oxygen, salinity, and Secchi disk depth for water-quality sites sampled from February 2003 to March 2004 at the Laguna de Las Salinas, Ponce, Puerto Rico ......................... 33

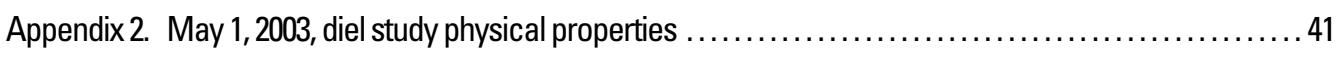

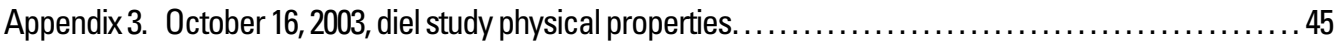

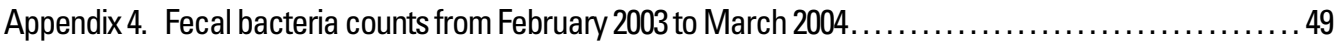




\section{Figures}

1-3. Maps showing:

1. Location of the Laguna de Las Salinas study area in the southern coast of Puerto Rico between the Río Inabón and Río Guayanilla basins .... .2

2. Comparison between the normal and the approximate flood-stage shorelines of the Laguna de Las Salinas, Ponce, Puerto Rico..... .4

3. The Laguna de Las Salinas drainage basin in the municipio of Ponce, Puerto Rico ..........5

4. Graph showing the relation between annual rainfall and annual pan evaporation at selected coastal sites in Puerto Rico.

5. Graphs showing ebb and flood flows to the Laguna de Las Salinas and relation with tide levels at the National Oceanographic and Atmospheric Administration tidal gage at Magueyes Island, (a) May 1 and (b) October 16, 2003 ......................................

6. Map showing bathymetry of Laguna de Las Salinas, Ponce, Puerto Rico ................... 11

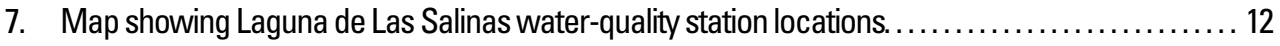

8-10. Graphs showing:

8. Percentages of dissolved carbon dioxide, bicarbonate ion, and carbonate ion as function of $\mathrm{pH}$ at $0^{\circ} \mathrm{C}$.

9. Dissolved oxygen, dissolved oxygen percent saturation, and rate of change curves for May 1, 2003, at station 4 in the Laguna de Las Salinas, Ponce, Puerto Rico ............ 23

10. The relation between phytoplankton biomass and gross productivity rates at the Laguna de Las Salinas from February 2003 to March 2004. 26

\section{Tables}

1. Sample matrix, quantity, container, and preservation method for selected analytes measured at the Laguna de Las Salinas, Ponce, Puerto Rico. ....

2. Comparison between the long-term mean monthly rainfall (1970-1998) at the National Oceanographic and Atmospheric Administration Ponce City and the Proteco Inc. stations during 2003

3. Laguna de Las Salinas station numbers, U.S. Geological Survey identification numbers, and properties measured

4. Total and dissolved nitrogen species concentration by collection date at station 4, from February 2003 to March 2004

5. Total and dissolved phosphorus species concentration by collection date at station 4, from February 2003 to March 2004

6. Total and dissolved organic carbon concentration average of stations 2 and 7 by collection date, from February 2003 to March 2004 .

7. Chlorophyll $a$ and $b$ concentration average of stations 2 and 7 by collection date, from February 2003 to March 2004

8. Primary productivity results at the Laguna de Las Salinas at station 2 obtained by the light and dark bottle method by collection date, from January 2003 to March $2004 \ldots \ldots \ldots \ldots \ldots \ldots \ldots . \ldots 21$

9. Primary productivity results at the Laguna de Las Salinas at station 7 obtained by the light and dark bottle method by collection date, from January 2003 to March $2004 \ldots \ldots \ldots \ldots \ldots \ldots \ldots 22$

10. Primary productivity results for the May 1, 2003, diel study at the Laguna de Las Salinas, Ponce, Puerto Rico.

11. Primary productivity results for the October 16, 2003, diel study at the Laguna de Las Salinas, Ponce, Puerto Rico.

12. Average phytoplankton biomass concentration at the Laguna de Las Salinas, Ponce, Puerto Rico, by collection date, from February 2003 to March 2004. 


\section{Conversion Factors and Datum, Water-Quality and Measurement Units, Acronyms, and Translations}

\begin{tabular}{|c|c|c|}
\hline Multiply & By & To obtain \\
\hline \multicolumn{3}{|c|}{ Length } \\
\hline centimeter (cm) & 0.3937 & inch (in.) \\
\hline millimeter (mm) & 0.03937 & inch (in.) \\
\hline meter (m) & 3.281 & foot (ft) \\
\hline kilometer (km) & 0.6214 & mile (mi) \\
\hline \multicolumn{3}{|c|}{ Area } \\
\hline square meter $\left(\mathrm{m}^{2}\right)$ & 0.0002471 & acre \\
\hline hectare (ha) & 2.471 & acre \\
\hline square kilometer $\left(\mathrm{km}^{2}\right)$ & 247.1 & acre \\
\hline square meter $\left(\mathrm{m}^{2}\right)$ & 10.76 & square foot $\left(\mathrm{ft}^{2}\right)$ \\
\hline square kilometer $\left(\mathrm{km}^{2}\right)$ & 0.3861 & square mile $\left(\mathrm{mi}^{2}\right)$ \\
\hline \multicolumn{3}{|c|}{ Volume } \\
\hline liter (L) & 0.2642 & gallon (gal) \\
\hline cubic meter $\left(\mathrm{m}^{3}\right)$ & 35.31 & cubic foot $\left(\mathrm{ft}^{3}\right)$ \\
\hline cubic meter $\left(\mathrm{m}^{3}\right)$ & 0.0008107 & acre-foot (acre-ft) \\
\hline \multicolumn{3}{|c|}{ Flow rate } \\
\hline cubic meter per second $\left(\mathrm{m}^{3} / \mathrm{s}\right)$ & 35.31 & cubic foot per second $\left(\mathrm{ft}^{3} / \mathrm{s}\right)$ \\
\hline cubic meter per day $\left(\mathrm{m}^{3} / \mathrm{d}\right)$ & 264.2 & gallon per day (gal/d) \\
\hline cubic meter per second $\left(\mathrm{m}^{3} / \mathrm{s}\right)$ & 22.83 & million gallons per day (Mgal/d) \\
\hline kilometer per hour $(\mathrm{km} / \mathrm{h})$ & 0.6214 & mile per hour (mi/hr) \\
\hline \multicolumn{3}{|c|}{ Mass } \\
\hline gram (g) & 0.03527 & ounce, avoirdupois (oz) \\
\hline kilogram (kg) & 2.205 & pound avoirdupois (lb) \\
\hline metric ton per year & 1.102 & ton per year (ton/yr) \\
\hline
\end{tabular}

Temperature in degrees Celsius $\left({ }^{\circ} \mathrm{C}\right)$ may be converted to degrees Fahrenheit $\left({ }^{\circ} \mathrm{F}\right)$ as follows:

$$
{ }^{\circ} \mathrm{F}=\left(1.8 \mathrm{x}^{\circ} \mathrm{C}\right)+32
$$

Datum:

Horizontal Datum - Puerto Rico Datum, 1940 Adjustment

Sea level: In this report, "sea level" refers to the National Geodetic Vertical Datum of 1929 (NGVD of 1929) a geodetic datum derived from a general adjustment of the first-order level nets of the United States and Canada, formerly called "Sea Level Datum of 1929".

\begin{tabular}{llll}
\multicolumn{4}{l}{ Abbreviated water-quality and measurement units used in this report: } \\
$\mathrm{L}$ & liter & $\mathrm{mg} / \mathrm{L}$ & milligrams per liter \\
$\mathrm{mL}$ & milliliter & $\mathrm{mgO} / \mathrm{L}$ & milligrams of oxygen per liter \\
$\mathrm{col} / 100 \mathrm{~mL}$ & colonies per 100 milliliter & $\mathrm{mgO} / \mathrm{L}-\mathrm{hr}$ & milligrams of oxygen per liter per hour \\
$\mathrm{g} / \mathrm{m}^{3}$ & grams per cubic meter & $\mathrm{ppt}$ & parts per thousand \\
$\mathrm{g} / \mathrm{cm}^{3}$ & grams per cubic centimeter & $\mu \mathrm{S} / \mathrm{cm}$ & microsiemens per centimeter \\
$\mathrm{gO} / \mathrm{m}^{3}$ & grams of oxygen per cubic meter & $\mu \mathrm{g} / \mathrm{L}$ & micrograms per liter \\
$\mathrm{gO} / \mathrm{m}^{3}-\mathrm{d}$ & grams of oxygen per cubic meter per day & &
\end{tabular}

\section{Acronyms used in this report:}

$\begin{array}{ll}\text { BLASS } & \text { Bathymetric/Land Survey System } \\ \text { GIS } & \text { Geographic Information System } \\ \text { GPS } & \text { Global Positioning System } \\ \text { NOAA } & \text { National Oceanographic and Atmospheric Administration } \\ \text { NWQL } & \text { National Water Quality Laboratory } \\ \text { PREOB } & \text { Puerto Rico Environmental Quality Board } \\ \text { TIN } & \text { Triangulated Irregular Network } \\ \text { USGS } & \text { U.S. Geological Survey } \\ \text { Translations } & \\ \text { Spanish } & \text { English } \\ \text { Laguna } & \text { Lagoon } \\ \text { Río } & \text { River } \\ \text { municipio } & \text { municipality }\end{array}$




\title{
Hydrologic, Water-Quality, and Biological Assessment of Laguna de Las Salinas, Ponce, Puerto Rico, January 2003-September 2004
}

\author{
By Luis R. Soler-López, Fernando Gómez-Gómez, and Jesús Rodríguez-Martínez
}

\section{Abstract}

The Laguna de Las Salinas is a shallow, 35-hectare, hypersaline lagoon (depth less than 1 meter) in the municipio of Ponce, located on the southern coastal plain of Puerto Rico. Hydrologic, water-quality, and biological data in the lagoon were collected between January 2003 and September 2004 to establish baseline conditions. During the study period, rainfall was about 1,130 millimeters, with much of the rain recorded during three distinct intense events. The lagoon is connected to the sea by a shallow, narrow channel. Subtle tidal changes, combined with low rainfall and high evaporation rates, kept the lagoon at salinities above that of the sea throughout most of the study. Water-quality properties measured on-site (temperature, $\mathrm{pH}$, dissolved oxygen, specific conductance, and Secchi disk transparency) exhibited temporal rather than spatial variations and distribution. Although all physical parameters were in compliance with current regulatory standards for Puerto Rico, hyperthermic and hypoxic conditions were recorded during isolated occasions. Nutrient concentrations were relatively low and in compliance with current regulatory standards (less than 5.0 and 1.0 milligrams per liter for total nitrogen and total phosphorus, respectively). The average total nitrogen concentration was 1.9 milligrams per liter and the average total phosphorus concentration was 0.4 milligram per liter. Total organic carbon concentrations ranged from 12.0 to 19.0 milligrams per liter. Chlorophyll $a$ was the predominant form of photosynthetic pigment in the water. The average chlorophyll $a$ concentration was 13.4 micrograms per liter. Chlorophyll $b$ was detected (detection limits 0.10 microgram per liter) only twice during the study. About 90 percent of the primary productivity in the Laguna de Las Salinas was generated by periphyton such as algal mats and macrophytes such as seagrasses. Of the average net productivity of 13.6 grams of oxygen per cubic meter per day derived from the diel study, the periphyton and macrophyes produced 12.3 grams per cubic meter per day; about 1.3 grams (about 10 percent) were produced by the phytoplankton (plant and algae component of plankton). The total respiration rate was 59.2 grams of oxygen per cubic meter per day. The respiration rate ascribed to the plankton (all organisms floating through the water column) averaged about 6.2 grams of oxygen per cubic meter per day (about 10 percent), whereas the respiration rate by all other organisms averaged 53.0 grams of oxygen per cubic meter per day (about 90 percent). Plankton gross productivity was 7.5 grams per cubic meter per day; the gross productivity of the entire community averaged 72.8 grams per cubic meter per day. Fecal coliform bacteria counts were generally less than 200 colonies per 100 milliliters; the highest concentration was 600 colonies per 100 milliliters.

\section{Introduction}

The municipio of Ponce is undergoing substantial economic transformations, as part of the municipal territorial management plans. A major development plan is a proposed transshipment port to be built in the south coast, about 5 kilometers (km) south of downtown Ponce (fig. 1). The port would add further pressure to develop lands in the periphery of Ponce, which would result in major land-use changes. One of the areas directly affected by the construction could be the Laguna de Las Salinas, a hypersaline lagoon located about 5 km west of the main port facilities (fig. 1). The municipio of Ponce is concerned that the development in the periphery of the Laguna de Las Salinas will negatively impact the lagoon. A similar south coast ecosystem, the former Laguna Las Mareas, located near the eastern limit of the south coastal plain in Guayama, was modified radically when it was dredged to construct port facilities, and was nearly converted into open coastal waters. Hence, the municipio is interested in restoring and protecting this aquatic ecosystem and plans to convert the Laguna de Las Salinas into a natural reserve in coordination with State and Federal agencies, as a mitigation activity to compensate for the possible impacts of future developments. From January 2003 to September 2004, the U.S. Geological Survey (USGS) in cooperation with the municipio of Ponce, collected hydrologic, bathymetric, biologic, as well as waterquality and fecal coliform data to define baseline conditions in the Laguna de Las Salinas. 


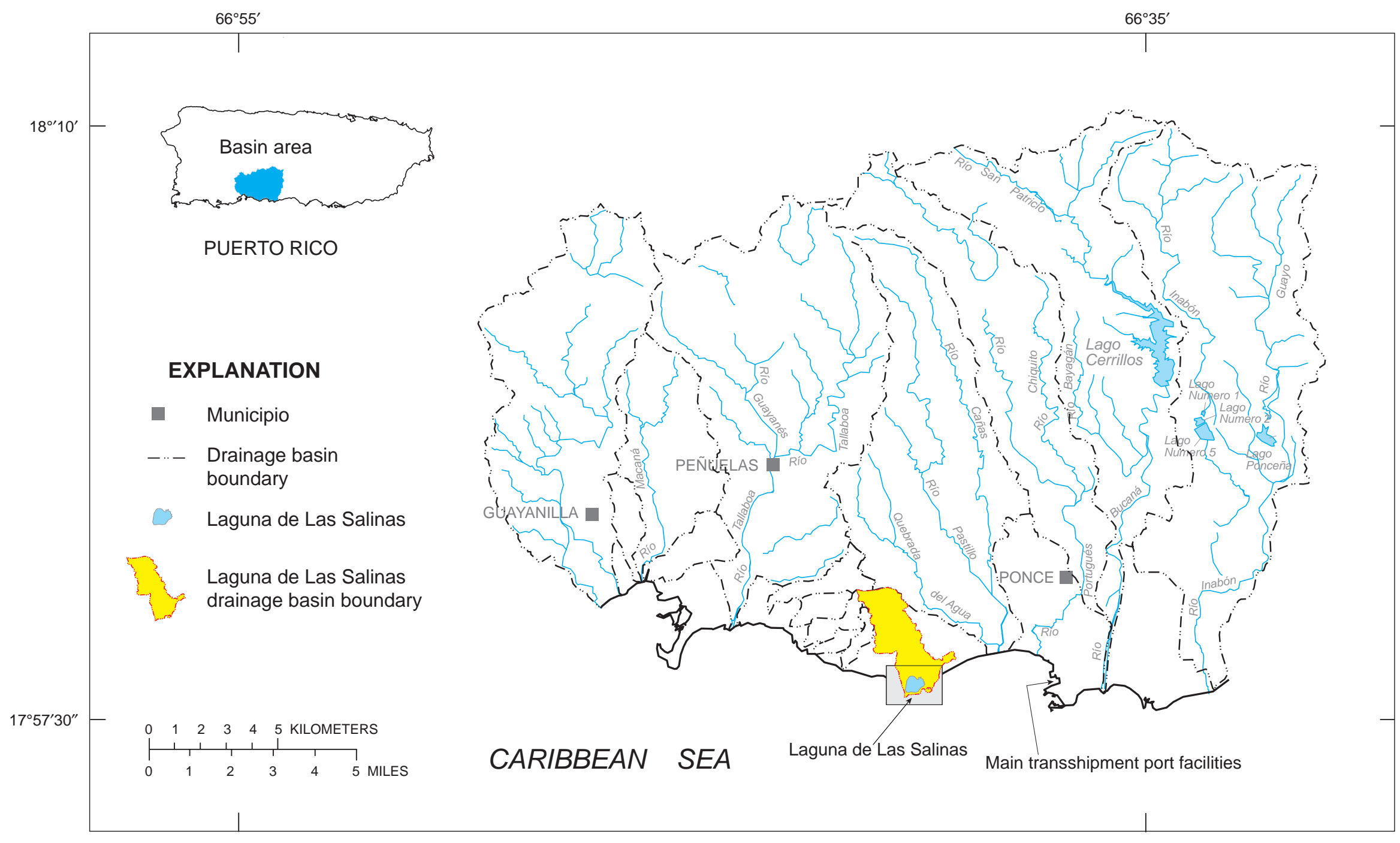

Figure 1. Location of the Laguna de Las Salinas study area in the southern coast of Puerto Rico between the Río Inabón and Río Guayanilla basins. 


\section{Description of Study Area}

The Laguna de Las Salinas is a shallow, 35-hectare (0.35-square kilometer; $\mathrm{km}^{2}$ ) shallow, hypersaline coastal lagoon located in the southern coastal plain of Puerto Rico, about $7.5 \mathrm{~km}$ southwest of the municipio of Ponce (fig. 1). The lagoon is one of the few remaining habitats of its kind in Puerto Rico. Many of these hypersaline coastal resources have been lost to siltation by runoff from agricultural areas or, as in the case of the Laguna Las Mareas, dredged for construction of port facilities. These types of coastal lagoons are ecologically important for various reasons. First, because of their shallow waters, sunlight penetrates through the entire water column promoting primary productivity. Second, during periods of above-normal rainfall, these habitats serve as buffers by retaining runoff and excess sediments, reducing their likelihood of transport to adjacent coastal waters and possible degradation of contiguous coral reefs. Third, these lagoons serve as nurseries for many fish, molluscs, and other invertebrates. Fourth, they provide refuge for resident and non-resident species of birds and other vertebrates. Fifth, these habitats serve as valuable natural laboratories where scientists and the public may acquire and expand their knowledge as well as enjoy recreational activities.

The Laguna de Las Salinas substrate is an assorted mixture of siliceous and carbonate clastics. The lagoon is connected to the Caribbean Sea by a relatively short, narrow and shallow channel, which is obstructed partially by mangrove roots (fig. 2). Water exchange with the sea is further limited by daily tidal oscillations of less than 30 centimeter $(\mathrm{cm})$. In addition, the high temperature regime in southern Puerto Rico and high evaporation rates create an environment in which air and water temperatures in the lagoon are typically about 1.5 degrees Celsius $\left({ }^{\circ} \mathrm{C}\right)$ higher, compared to the adjacent open sea. Water contained in the lagoon becomes hypersaline during periods of low rainfall; salinities commonly exceed 40 parts per thousand (ppt). Under the extreme conditions created by the reduced hydraulic connection with the sea (which limits the water renewal rate and enhances evaporation), the fauna present are a few euryhaline species such as polykeets, shellfish, snails, seagrasses, fiddler crabs, and some types of fishes, who have adapted to such stressful and unique environments.

No perennial or ephemeral streams discharge into the lagoon. Freshwater influx occurs during the rare, intense rainfall that occurs principally during August through November. These uncommon rainfall events can decrease the salinity and temperature of the lagoon in a short time. During heavy rainfall, the lagoon's surface area can increase substantially (from 35 to about 70 hectares or more, fig. 2). The surface area expansion caused by the large amounts of freshwater runoff also affects the type of vegetation and organisms that live in the lagoonal littoral zone. The increased lagoon stage, resulting from excess runoff, may be sufficient to overcome the normal daily tidal fluctuations.

The lagoon is bound by mangroves in about 75 percent of its immediate periphery. The mangrove plant community includes red (Rhizophora mangle), white (Laguncularia racemosa), black (Avicennia germinans), and button
(Conocarpus erectus) mangrove and covers an estimated 1.5 hectares. Other plant species that live on the external periphery of the lagoon, along the Caribbean Sea shore, include the sebucán cactus (Cephalocereus royenii), the tachuelo tree/shrub (Pictetia aculeata), and the beachwort (Batis maritima).

The drainage area of the Laguna de Las Salinas is about $6.3 \mathrm{~km}^{2}$, as delineated from the USGS 1:20,000 scale Punta Cucharas topographic quadrangle. The construction of the Las Cucharas Penitentiary (fig. 3), however, reduced the drainage area along the west flank of the basin by about $0.2 \mathrm{~km}^{2}$ resulting in a net Laguna de Las Salinas basin of about $6.1 \mathrm{~km}^{2}$ (fig. 3). The drainage area is underlain by the Juana Díaz Formation in the upland (northern) area and by the Ponce Limestone near the coast (J. Rodríguez-Martínez, U.S. Geological Survey, oral commun., 2003). The Juana Díaz Formation consists of finegrained, highly clayey limestones, and it is not considered to be an aquifer. Test wells drilled into the Juana Díaz Formation, just west of the Laguna de Las Salinas drainage basin at the Proteco Inc. site (fig. 3), showed hydraulic conductivities that ranged from $10^{-9}$ to $10^{-3}$ centimeters per second (OHM Remediation Services Corp., 1992; Krushensky and Monroe, 1978). The low hydraulic conductivity values indicate that the Juana Díaz Formation is a poor water-bearing unit. Since the Ponce Limestone in the study area is lithologically similar to the Juana Díaz Formation, it can be concluded that the Ponce Limestone is also a poor water-bearing unit and is not considered to be an aquifer.

\section{Purpose and Scope}

The purpose of this report is to help managing authorities develop plans for the preservation of the Laguna de Las Salinas by providing baseline information to describe the general hydrologic, water-quality, and biological characteristics of the lagoon. These characteristics were measured from January 2003 to September 2004. The information obtained from this study will be used to elaborate land-use strategies to ensure the preservation of the Laguna de Las Salinas. Information from this study helps increase understanding of shallow, hypersaline lagoons in other coastal areas of the Nation.

The study consisted of three basic components of data compilation and collection: (1) hydrologic characteristics, (2) water quality, and (3) biological characteristics. Hydrologic characteristics analyzed included rainfall, evaporation, surfacewater runoff, ground-water interaction with the lagoon, water exchange between the sea and the lagoon, and a bathymetric survey to describe the lagoon's bottom topography and to estimate the water volume contained in the lagoon at mean sea level. Water quality included the measurement of on-site properties, such as water temperature, $\mathrm{pH}$, dissolved oxygen, specific conductance, Secchi disk transparency, and the concentration of total and dissolved nutrients and organic carbon, as well as chlorophyll $a$ and $b$ concentrations. Biological characteristics included primary and gross productivity, phytoplankton biomass, and fecal coliform bacteria quantification. 


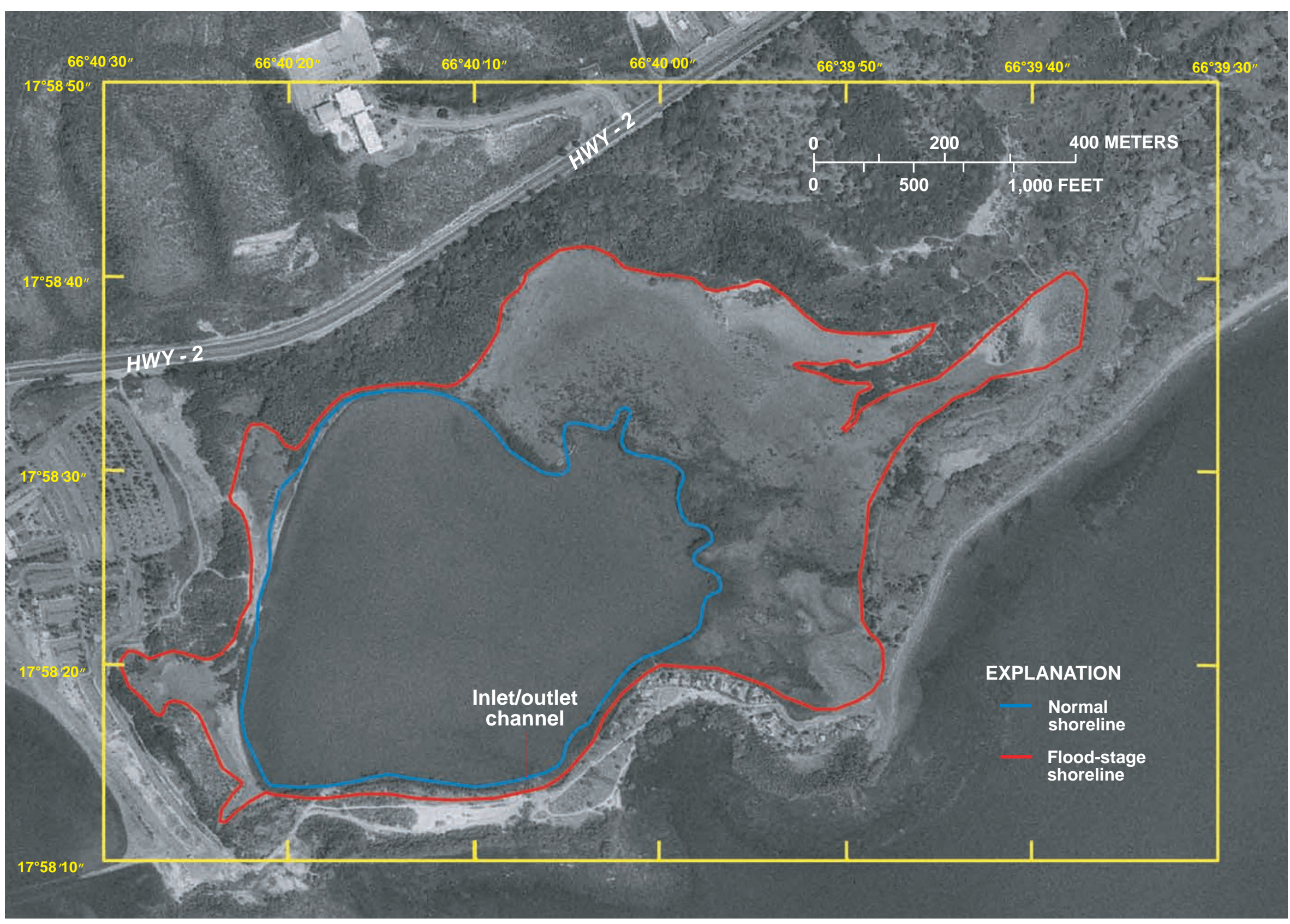

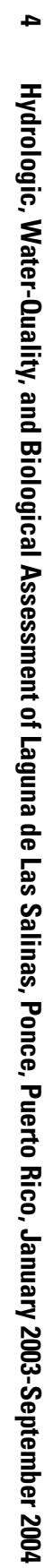

Figure 2. Comparison between the normal and the approximate flood-stage shorelines of the Laguna de Las Salinas, Ponce, Puerto Rico. 


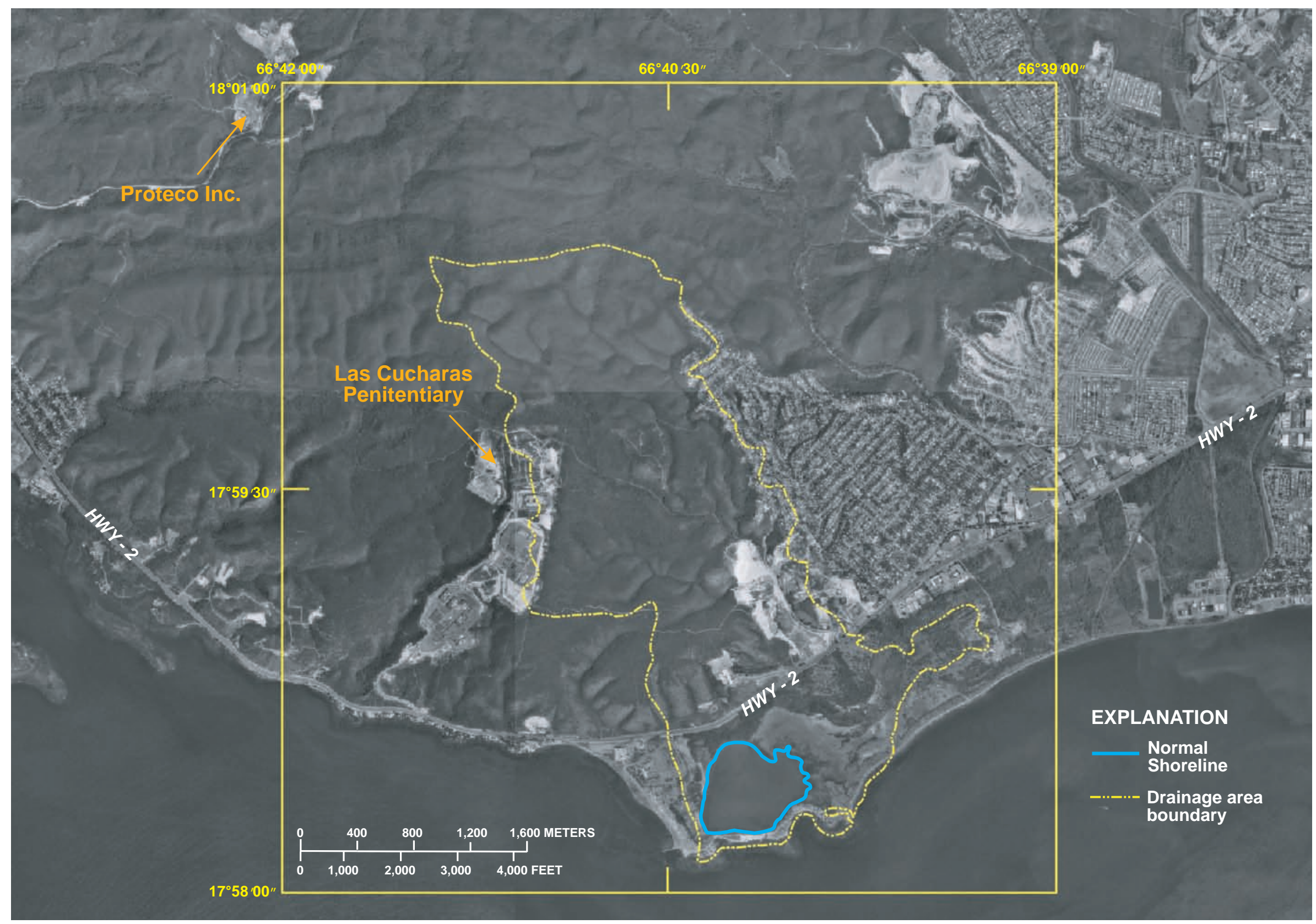

Figure 3. The Laguna de Las Salinas drainage basin in the municipio of Ponce, Puerto Rico. 


\section{Acknowledgments}

The authors acknowledge the support of Eduardo Questell, retired geologist of the municipio of Ponce, particularly in the early phases of this study. The authors also acknowledge the support provided by the municipal public officials José Valenzuela and Patrick Urbain of the Territorial Development Office of the municipio of Ponce.

\section{Methods}

Hydrologic characteristics of the Laguna de Las Salinas were obtained from previous studies as well as field measurements using USGS standard methods. Rainfall in the drainage area was estimated from the nearby (5 km northwest) Proteco Inc. raingage. The evaporation rate for the Laguna de Las Salinas was estimated from previous coastal Puerto Rico pan-evaporation studies. Surface-water runoff was estimated based on the lagoon-stage increase after heavy rainfall. Groundwater interaction with the lagoon was estimated using the Proteco Inc. hydraulic conductivity data. Water exchange between the sea and the lagoon for periods of low and high tides were determined by a series of discharge measurements at the lagoon inlet channel using USGS standard wading methods (Quiñones-Márquez and Guzmán-Ríos, 1985). The bathymetric survey was conducted using global positioning system (GPS) technology and a digital acoustic depth sounder.
Water-quality determinations included selected physical and chemical characteristics, and fecal coliform bacteria concentration. Water physical characteristics were obtained using a YSI multi-parameter instrument that measures temperature, $\mathrm{pH}$, dissolved oxygen, specific conductance, and salinity derived from specific conductance. Water transparency was measured using a Secchi disk. Water chemical characteristics were measured by collecting samples in designated bottles and containers. Nutrients and organic carbon were collected, preserved, and sent to the National Water Quality Laboratory (NWQL) in Denver, Colorado, for analysis. Chlorophyll samples were collected in designated bottles, filtered on-site using designated filters, and sent to the NWQL for analysis.

Selected water biological characteristics of the Laguna de Las Salinas were determined using standard USGS methods. Phytoplankton biomass concentration was measured by collecting samples in designated bottles, filtering water on-site using designated filters, and shipped overnight to the NWQL for analysis. Fecal coliform bacteria measurements were made by collecting samples in sterilized bottles, filtering on-site immediately after collection, and incubating at specific temperatures for specific periods of time. After analytical procedures, fecal bacteria colonies were counted and their concentrations were determined.

General information about sample quantities, sample containers, and preservation methods, used for individual chemical and biological samples are listed in table 1. Details about specific methods used are presented at the beginning of each analyte results and discussion section.

Table 1. Sample matrix, quantity, container, and preservation method for selected analytes measured at the Laguna de Las Salinas, Ponce, Puerto Rico.

[mL, milliliter; mm, milllimeter; L, liter; ${ }^{\circ} \mathrm{C}$, degrees Celsius; $\mathrm{H}_{2} \mathrm{SO}_{4}$, Sulfuric acid; N, normality; $\mu$, micron]

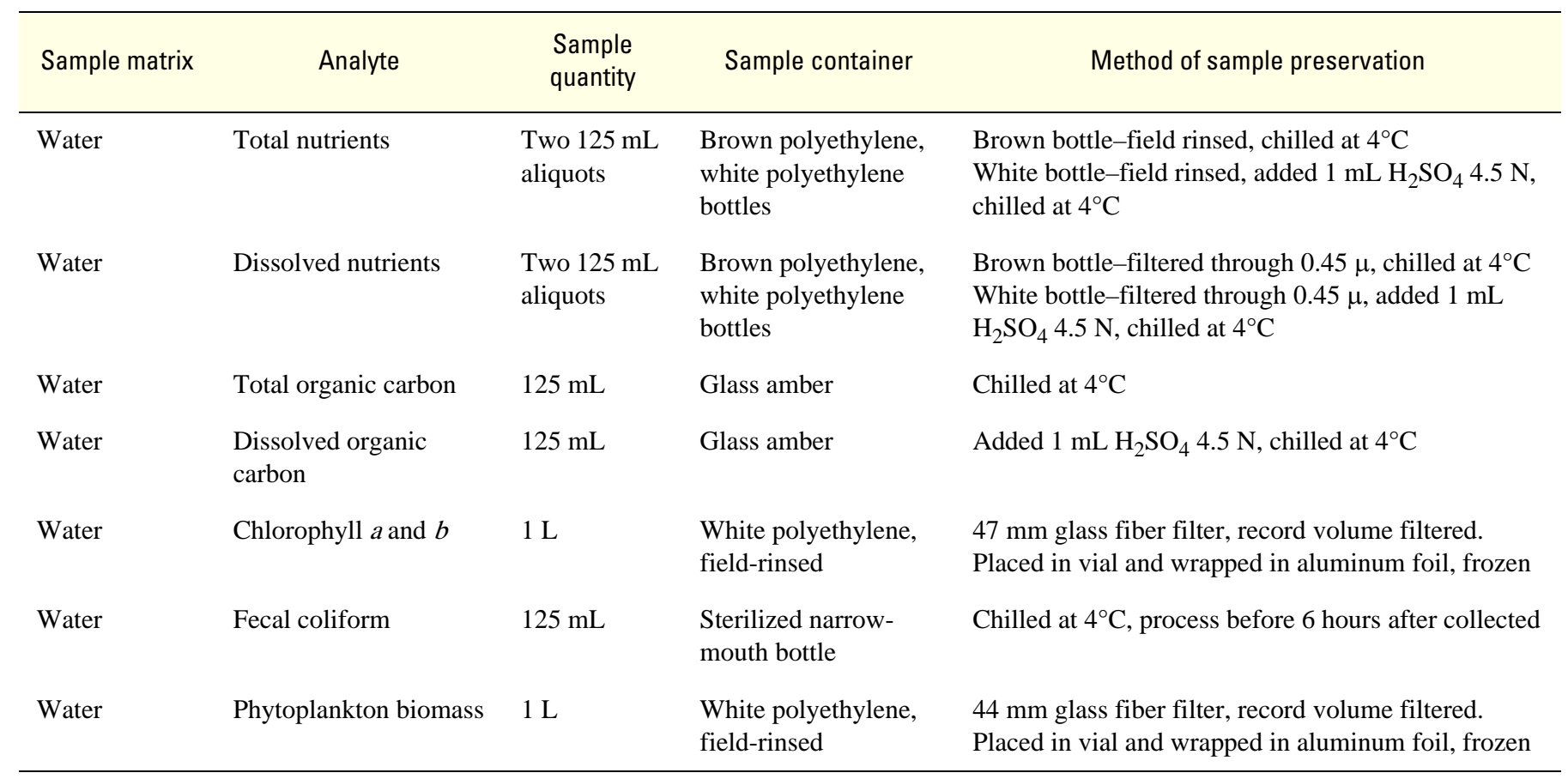




\section{Hydrologic Characteristics}

The long-term distribution of monthly rainfall at the Laguna de Las Salinas was considered similar to that available for the Ponce City National Oceanographic Atmospheric Administration (NOAA) observation station, because of their proximity of about $5 \mathrm{~km}$ (table 2) (National Oceanographic and Atmospheric Administration, 1970-1998). During the study period, rainfall in the Laguna de Las Salinas drainage area was assumed to be equal to that recorded about $2 \mathrm{~km}$ northwest of the upper Laguna de Las Salinas basin at the Proteco Inc. site. Although the long-term mean annual rainfall in the lagoon drainage area is estimated to be at about 697 millimeters $(\mathrm{mm})$ (table 2), in 2003, about 1,130 mm were recorded by Proteco Inc. (Proteco Inc., written commun., 2003); about 160 percent of the annual average. The long-term monthly rainfall was exceeded by more than 150 percent for 7 months, once by more than 700 percent, and once by more than 1,100 percent. The three highest estimated monthly rainfall amounts occurred during April, November, and December 2003. During May, June, and October 2003, rainfall was considerably lower than the long-term average (table 2).

Evaporation rate is defined as the quantity of water, expressed in terms of depth of liquid water, that is evaporated from a given surface per unit of time. Evaporation rate is usually expressed in millimeters depth, per day, month, or year (National Weather Service, 1997). High evaporation rates are common in the southern coastal area of Puerto Rico, principally because of the high temperatures and persistent southeast winds. These evaporation rates can be estimated by conducting typical pan evaporation studies, in which a standard 122-cm-diameter, 25-cm-high metal pan, is used to contain water during observations for the determination of the quantity of water evaporated at a given location.
The annual pan evaporation rate of the Laguna de Las Salinas was estimated by comparing the relation of annual rainfall to pan evaporation from several studies conducted in coastal areas of Puerto Rico with different annual rainfall regimes (Anderson, 1977; Gómez-Gómez, 1984; SantiagoRivera and Quiñones-Aponte, 1995; Rodríguez-Martínez, 1996). There is a linear correlation between annual rainfall and annual pan evaporation at selected coastal sites in Puerto Rico (fig. 4). Based on the mean annual long-term rainfall of 697 millimeters per year ( $\mathrm{mm} / \mathrm{yr}$ ) (National Oceanographic and Atmospheric Administration, 1970-98), the extrapolated pan evaporation rate in the Laguna de Las Salinas is about $1,850 \mathrm{~mm} / \mathrm{yr}$. This value is close to the estimate of about $1,700 \mathrm{~mm} / \mathrm{yr}$ for the south coast (U.S. Geological Survey, 1997). Although the evaporation rate in the Laguna de Las Salinas is more than double the mean annual rainfall, the lagoon does not dry up because seawater is supplied daily by tides.

The Laguna de Las Salinas drainage area has no ephemeral or perennial streams. Runoff in the basin is considered minimal and occurs predominantly in the form of infrequent, intense rainfall. During 2003, intense rainfall was observed on April 17-18, November 11-13, and December 6-7. During the highest rainfall event on April 17-18, 2003, 214 mm of rain were recorded. Multiplying the lagoon surface area of 350,000 square meters $\left(\mathrm{m}^{2}\right)$ by the lagoon stage increase of $4.32 \mathrm{~mm}$ as measured at a reference point between the April 12, 2003, and the May 1, 2003, visits gives an estimated volume increase of 1,512 cubic meters $\left(\mathrm{m}^{3}\right)$ of water, or about 0.5 percent of the incident rainfall amount. This number divided by the lagoon drainage area of $6.1 \mathrm{~km}^{2}$ gives an estimated runoff of at least 250 cubic meters per square kilometer $\left(\mathrm{m}^{3} / \mathrm{km}^{2}\right)$ for the 2-day period. This estimate, however, represents high-rainfall conditions and does not take into account possible seawater influx or possible evaporation.

Table 2. Comparison between the long-term mean monthly rainfall (1970-1998) at the National Oceanographic and Atmospheric Administration (NOAA) Ponce City and the Proteco Inc. stations during 2003.

[mm, millimeters]

\begin{tabular}{|c|c|c|c|c|c|c|c|c|c|c|c|c|c|}
\hline Month & Jan. & Feb. & Mar & Apr. & May & June & July & Aug. & Sept. & 0ct. & Nov. & Dec. & $\begin{array}{l}\text { Mean } \\
\text { annual } \\
\text { rainfall }\end{array}$ \\
\hline
\end{tabular}




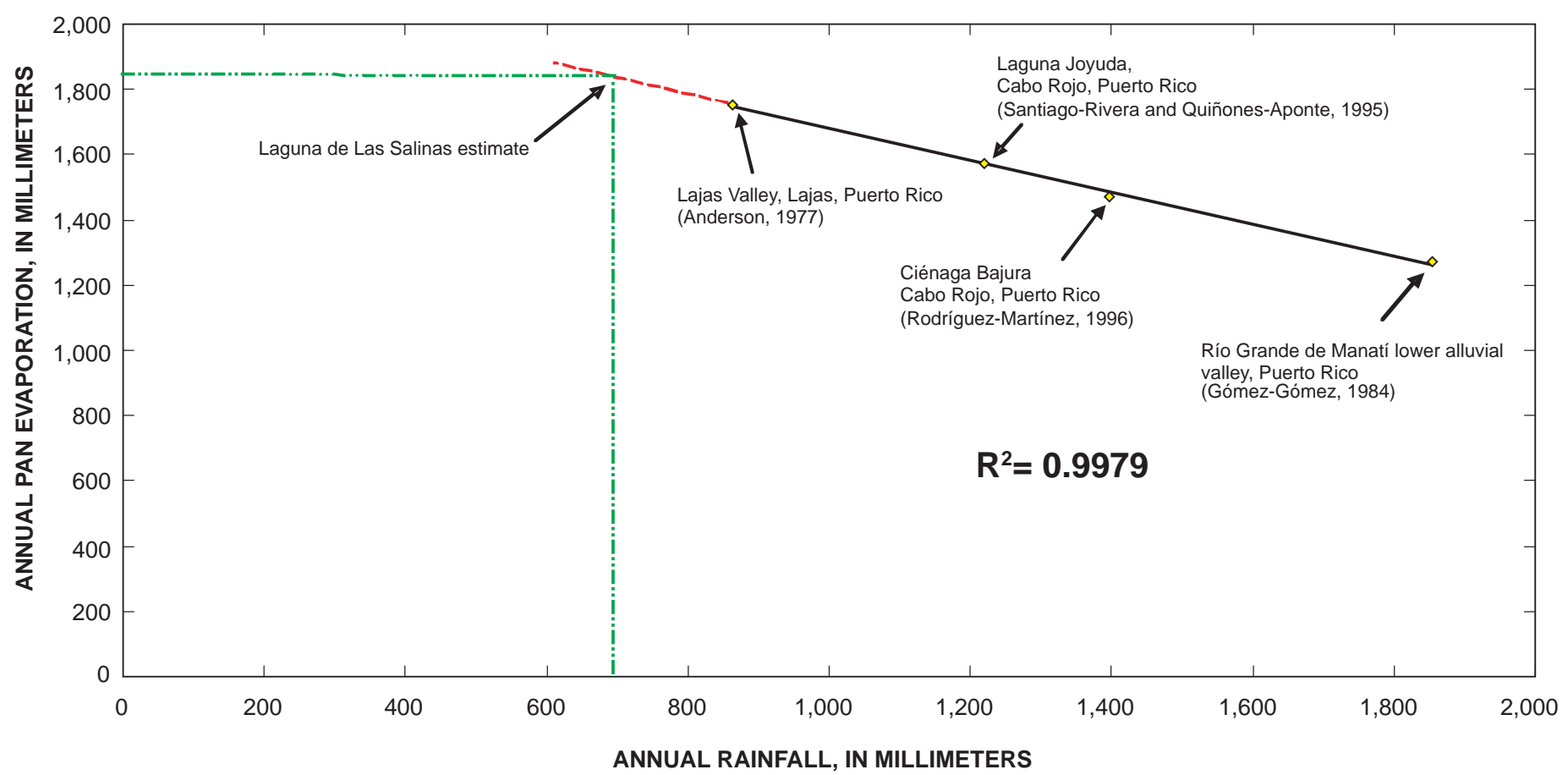

Figure 4. Relation between annual rainfall and annual pan evaporation at selected coastal sites in Puerto Rico.

Water exchange between the Laguna de Las Salinas and the sea is through a narrow, shallow channel, and is controlled by subtle tidal fluctuations in the Caribbean Sea, and to some extent by the winds. Typically, mean daily tidal fluctuations measured at the NOAA tidal gage located in La Parguera (about $30 \mathrm{~km}$ west of the Laguna de Las Salinas) are in the range of 20 $\mathrm{cm}$ above and below mean sea level. The difference between the mean annual high tide (period of October-November) and mean annual low tide (period of April-May) is about $10 \mathrm{~cm}$. Water flow was measured at the channel using USGS standard methods to determine flow in and out of the Laguna de Las Salinas. Measurements were taken on May 1, 2003, at hourly intervals (6:00 a.m. to 7:00 p.m.), to calculate the ebb (out) and flood (in) tide flows. Total flow during the ebb tide was 2,813 $\mathrm{m}^{3}$ and the partial flood flow was $763 \mathrm{~m}^{3}$. The lagoon stage (level) did not change during this cycle. The water flow and the tide pattern corresponded until about 1:00 p.m. While the tide remained low, the flow pattern began to shift towards the flood flow at about 2:00 p.m. (fig. 5a). Data collected during the same period indicated that wind speed was between 8 and 10 kilometers per hour $(\mathrm{km} / \mathrm{hr})$ in the southeastern direction during the morning, and was substantially higher, about 19 to 29 $\mathrm{km} / \mathrm{hr}$, in the southeastern direction after 12:00 noon. A comparison between the wind speed at the coast in the Laguna de Las Salinas and the tide level at La Parguera indicates that wind speeds in excess of $16 \mathrm{~km} / \mathrm{hr}$ from the southeast may increase sea level along the south coast by about $30 \mathrm{~cm}$ above that in the open sea. Thus, the normal ebb and flood tide flows out of and into the Laguna de Las Salinas are influenced by the rise and fall of the daily tides and by the wind.

The October 16, 2003, daylight hours ebb and flood tide flows were measured from 6:00 a.m. to 6:00 p.m. and were calculated to be 3,953 and $2,841 \mathrm{~m}^{3}$, respectively. In this case, the flow pattern followed the tide harmonically (fig. 5b). The lagoon stage did not change during this period. During October 16, the wind speed remained low (less than $8 \mathrm{~km} / \mathrm{hr}$ from the southeast) and had a negligible or no effect on the normal water exchange with the sea.

\section{Bathymetric Survey}

A bathymetric survey of the Laguna de Las Salinas was conducted on September 23, 2004, to contour the lagoon's bottom and to calculate the water volume at mean sea level. A bathymetric/land survey system (BLASS) interfaced to a depth sounder was used to conduct the survey. The system consists of a Novatel GPS and a digital depth sounder (Intelligent Depth, Specialty Devices Inc.). Data on geographic location and water depth were simultaneously collected and stored in a portable computer. The data were then transferred into the USGS geographic information system (GIS) for processing and analysis. 


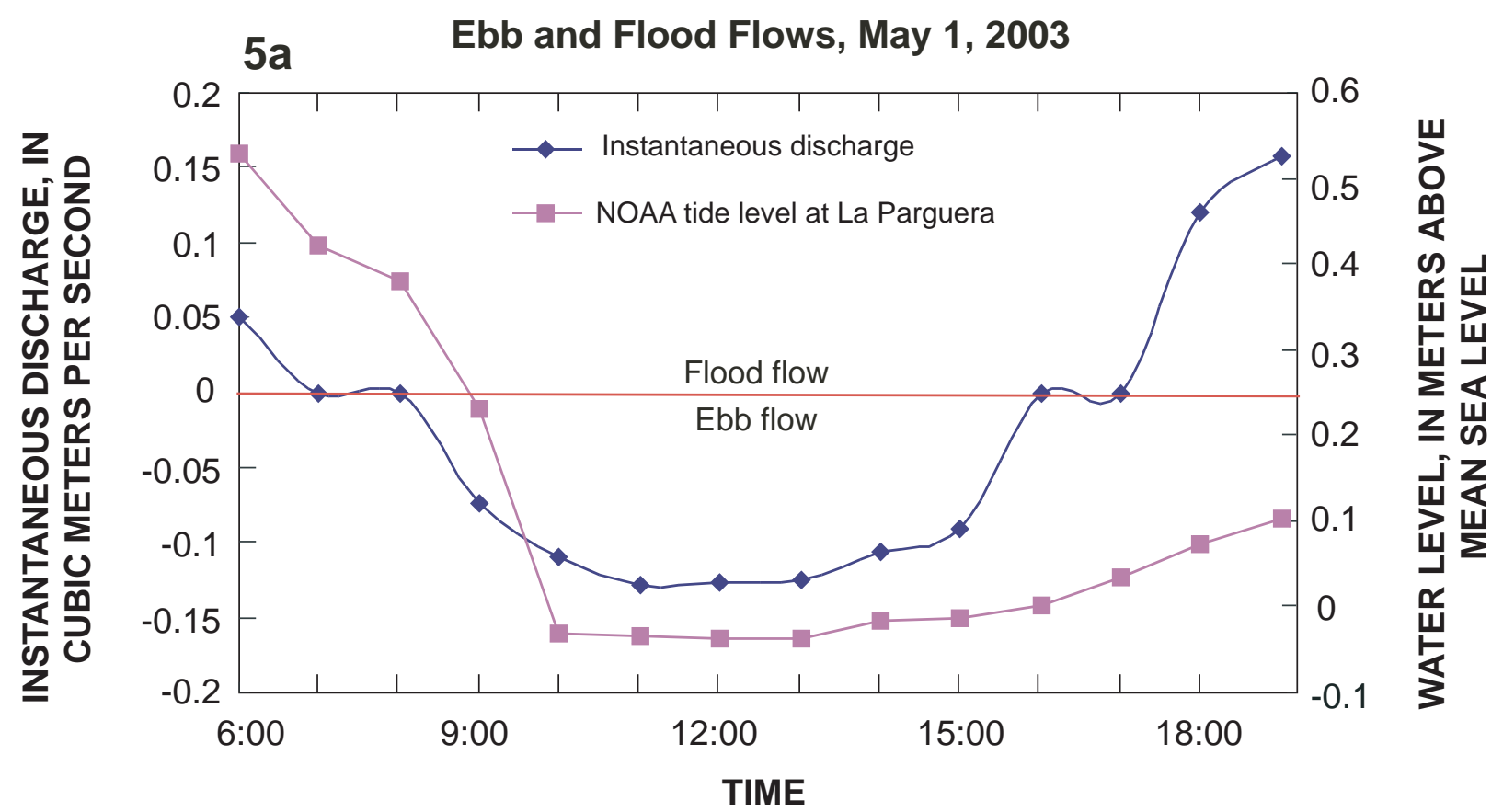

5b Ebb and Flood Flows, October 16, 2003

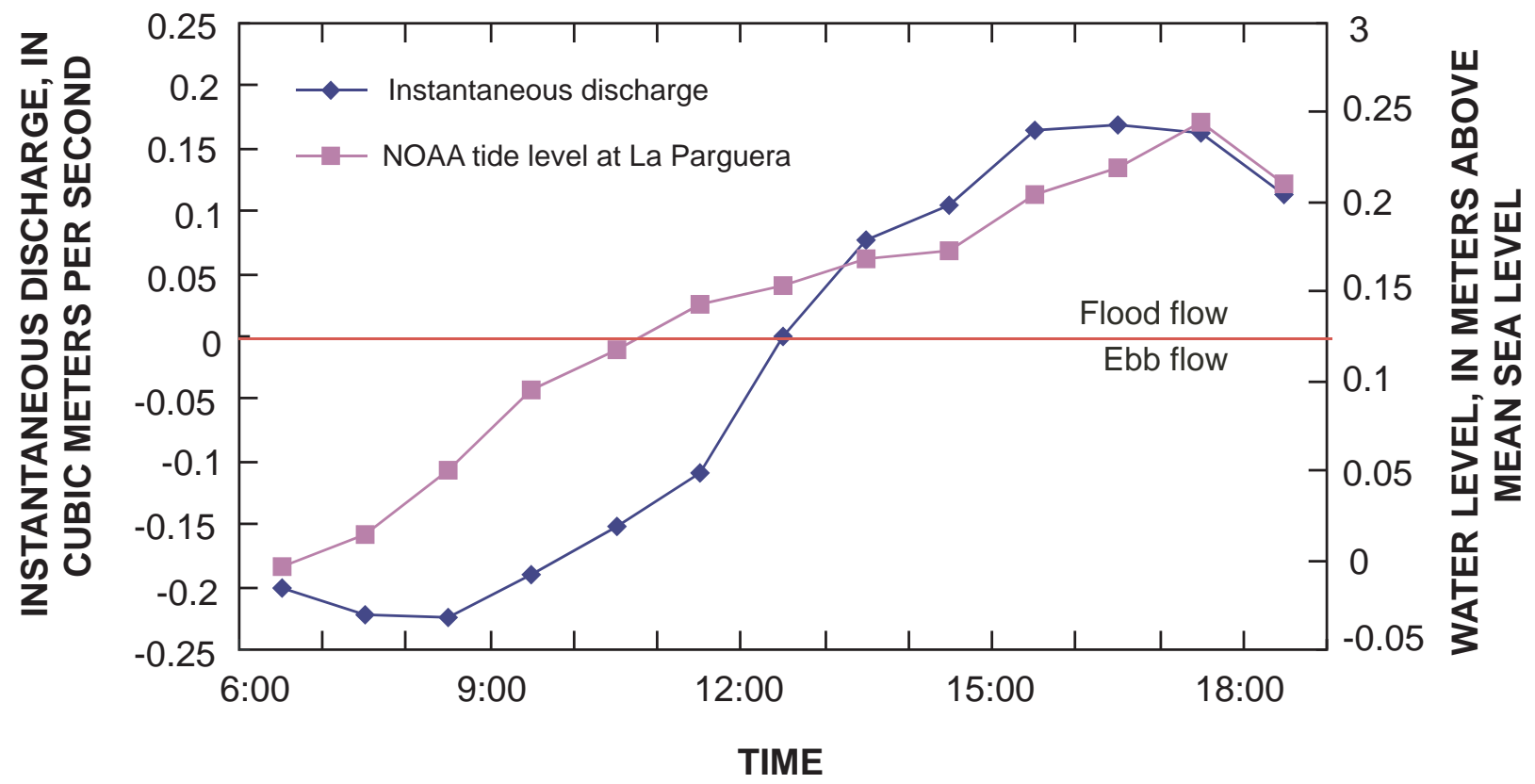

Figure 5. Ebb and flood flows to the Laguna de Las Salinas and relation with tide levels at the National Oceanographic and Atmospheric Administration (NOAA) tidal gage at Magueyes Island, (a) May 1 and (b) October 16, 2003. 
After the data reduction process, the lagoon's bottom was contoured (fig. 6) and then converted into a triangulated irregular network (TIN) to calculate the volume. The TIN represents the lagoon's bottom surface model as thousands of adjoining triangles with $\mathrm{x}, \mathrm{y}$, and $\mathrm{z}$ coordinates assigned to all vertices (Environmental Systems Research Institute, Inc., 1992). The Laguna de Las Salinas has a volume of $217,000 \mathrm{~m}^{3}$ at mean sea level datum. The bottom has little relief, with a maximum depth of $90 \mathrm{~cm}$ below mean sea level in the western portion of the lagoon. The mean depth is about $60 \mathrm{~cm}$ and most of the lagoon has depths ranging from 50 to $70 \mathrm{~cm}$ below mean sea level. The shallower areas are in the southern portion of the lagoon. Sedimentation could be occurring at a faster rate in these areas from the effects of extreme storm surges and/or deposition of beach sand drifted by persistent southeast winds. Determination of the prevalent mechanism of sedimentation in the lagoon would require more detailed analyses. Although a sediment deposition rate cannot be determined from the available data, the vertical accretion rate determined for a similar shallow lagoon, Laguna de Piñones located in the San Juan Bay Estuary System in northern Puerto Rico, was estimated at 0.24 centimeter per year $(\mathrm{cm} / \mathrm{yr}$ ) (Webb and Gómez-Gómez, 1997). If this sedimentation rate is applied to the Laguna de Las Salinas (mean water depth of about $60 \mathrm{~cm}$ ), the lagoon would fill with sediments in approximately 250 years.

\section{Water Quality}

Selected physical characteristics of the water in the Laguna de Las Salinas were measured on-site at eight sites using a multi-parameter water-quality instrument (fig. 7). Measurements included temperature, $\mathrm{pH}$, dissolved oxygen, specific conductance, salinity, and Secchi disk water transparency. At three of these sites, samples were collected for chemical analysis of nutrients, organic carbon, and chlorophyll $a$ and $b$ concentrations, as well as fecal bacteria concentrations. Table 3 lists the physical and chemical properties measured at each station. Data collected at about monthly intervals from January 2003 to March 2004 are listed in appendix 1.

Water-quality standards for surface water in Puerto Rico have been established by the Puerto Rico Environmental Quality Board (PREQB) on the basis of the designated or intended use, including fishing, swimming, or source for public supply. The Laguna de Las Salinas is classified by the PREQB as SB coastal and estuarine waters used or intended for use in primary and secondary contact recreation and for propagation and preservation of desirable species (Puerto Rico Environmental Quality Board, 2003). For this study, the PREQB standards for SB type waters were used in evaluating the Laguna de Las Salinas water-quality data.

Table 3. Laguna de Las Salinas station numbers, USGS identification numbers, and properties measured.

\begin{tabular}{|c|c|c|}
\hline $\begin{array}{c}\text { Station number } \\
\text { (refer to figure } 7 \text { for } \\
\text { locations) }\end{array}$ & $\begin{array}{l}\text { U.S. Geological Survey } \\
\text { identification number }\end{array}$ & Properties measured \\
\hline Station 1 & 50119300 & Physical properties ${ }^{1}$ \\
\hline Station 2 & 50119310 & $\begin{array}{l}\text { Physical properties, total organic carbon, dissolved organic } \\
\text { carbon, primary productivity, biomass, chlorophyll } a \text { and } b\end{array}$ \\
\hline Station 3 (channel) & 50119320 & Physical properties, fecal bacteria \\
\hline Station 4 & 50119330 & Physical properties, total and dissolved nutrients, bacteriology \\
\hline Station 5 & 50119340 & Physical properties \\
\hline Station 6 & 50119350 & Physical properties \\
\hline Station 7 & 50119360 & $\begin{array}{l}\text { Physical properties, total organic carbon, dissolved organic } \\
\text { carbon, primary productivity, biomass, chlorophyll } a \text { and } b\end{array}$ \\
\hline Station 8 & 50119370 & Physical properties, fecal bacteria \\
\hline
\end{tabular}

\footnotetext{
${ }^{1}$ Temperature, pH, dissolved oxygen, specific conductance, salinity, Secchi disk water transparency.
} 


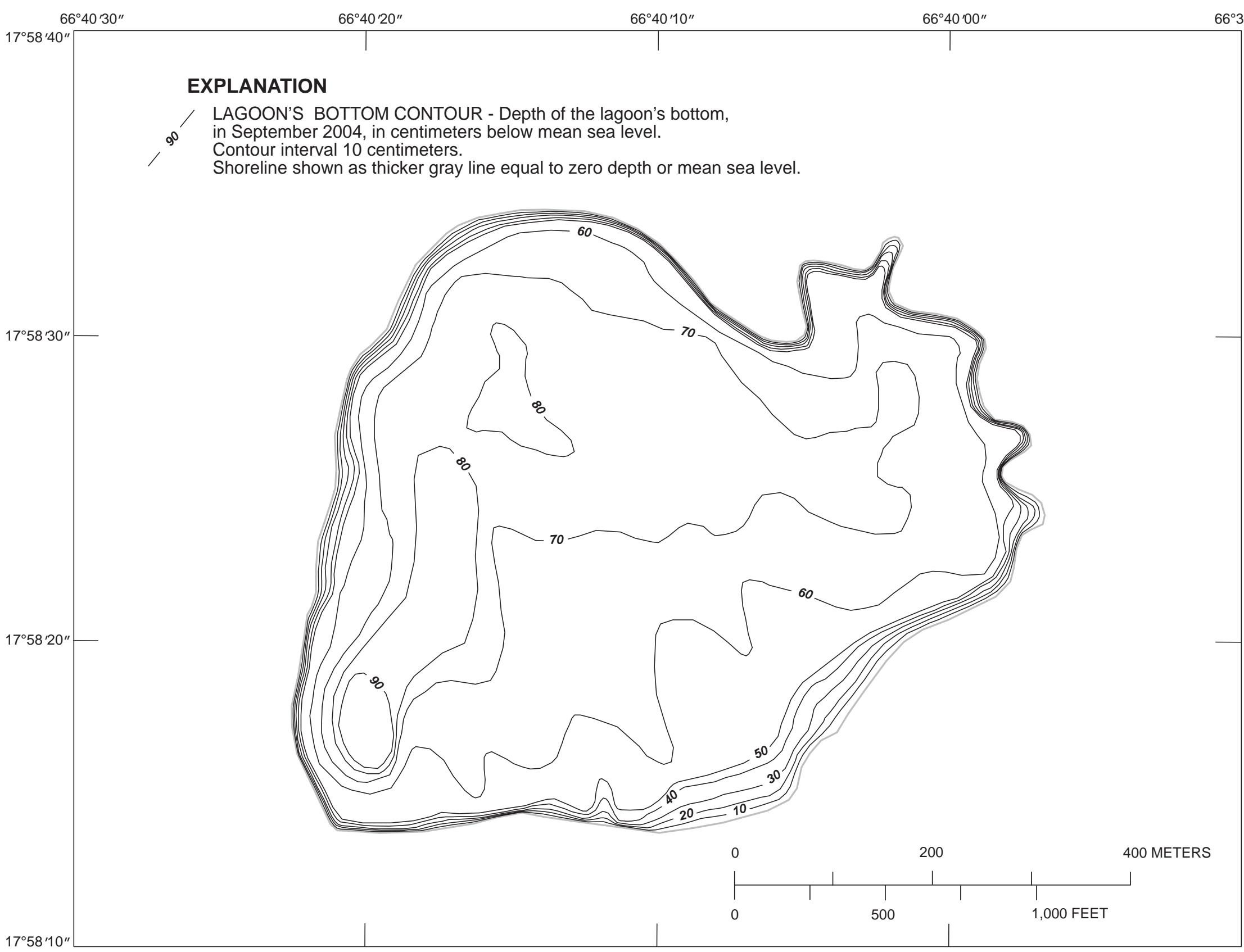

Figure 6. Bathymetry of Laguna de Las Salinas, Ponce, Puerto Rico. 


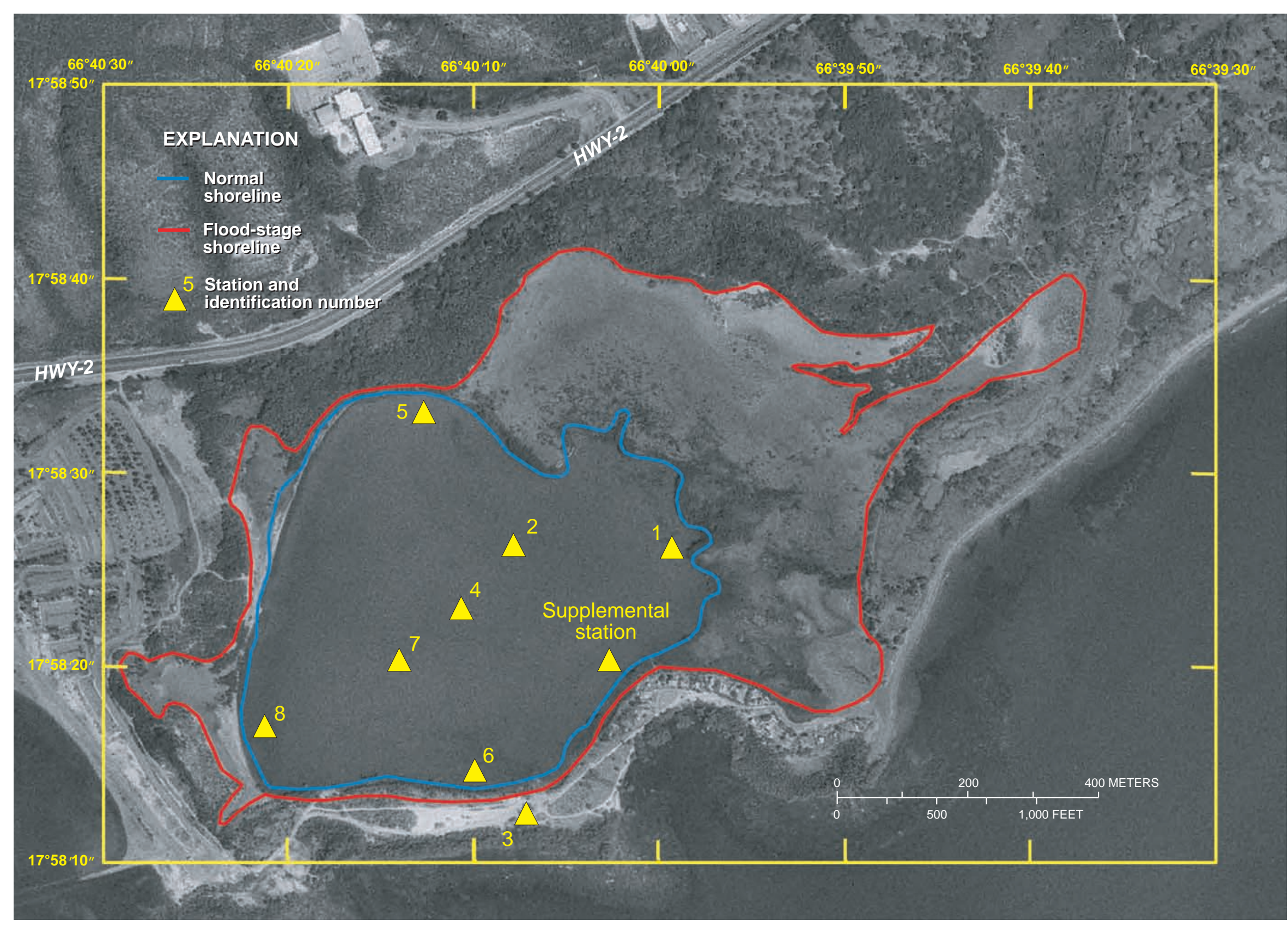




\section{Water Physical Properties}

The water physical properties determined at the Lagunas de Las Salinas were temperature, $\mathrm{pH}$, dissolved oxygen, specific conductance, salinity, and Secchi disk water transparency.

\section{Temperature}

Water temperature, in ${ }^{\circ} \mathrm{C}$, was measured at all stations on a nearly monthly basis during the morning hours. Temperature was measured near the top and the bottom of the water column. At station 3, the shallow sea outlet channel, only top measurements were collected; however, temperature was also measured in the afternoon to document any change. Water temperatures were determined to be distributed homogeneously within the lagoon during each sampling. Temporal (not spatial) temperature variability occurred in the lagoon, and were associated with the season of the year. In addition, top and bottom values at all stations were similar, showing no vertical stratification within the relatively shallow lagoon.

Excluding the channel (station 3) from this summary, the lowest temperature $\left(24^{\circ} \mathrm{C}\right)$ was measured during the February 2004 sampling at station 6 , with the highest temperature $\left(30.5^{\circ} \mathrm{C}\right)$ recorded during October 2003 at the same station. In general, temperature ranges can be divided into two categories. During the winter months (November, December, January, and February) the temperature ranged from 24 to $26^{\circ} \mathrm{C}$. During the rest of the year, from March to October, the temperature was higher, ranging from 27 to $31^{\circ} \mathrm{C}$, with a drop back to the winter values after October. Although temperature was not recorded in the afternoon at all stations, measurements made at stations 2 and 7 (near the center of the lagoon) on every sampling trip indicated a water temperature increase of about 1 to $1.5^{\circ} \mathrm{C}$, compared to the morning measurements. Based on the estimated lagoon water volume of $217,000 \mathrm{~m}^{3}$ and the estimated seawater density of 1.025 gram per cubic centimeter $\left(\mathrm{g} / \mathrm{cm}^{3}\right)$, the temperature increase is equivalent to a heat energy gain of about 340 billion calories. At the channel (station 3), morning values ranged from about $25^{\circ} \mathrm{C}$ (during December 2003) to about $30^{\circ} \mathrm{C}$ (during September and October 2003). Afternoon values ranged from about 27 to $34^{\circ} \mathrm{C}$ (during March 2004 and May 2003, respectively). The morning average temperature at the channel (about $27^{\circ} \mathrm{C}$ ) was very close to the morning average temperature of the lagoon $\left(27.5^{\circ} \mathrm{C}\right)$. The lagoon afternoon average temperature was about $28^{\circ} \mathrm{C}$, and the channel average afternoon temperature was about $31^{\circ} \mathrm{C}$.

Nearly all temperature measurements at the Laguna de Las Salinas complied with the PREQB standards for SB waters, which establish that water temperature should not increase above $32.2^{\circ} \mathrm{C}$. Temperature measurements exceeded the standard at the channel on only two occasions, for the afternoon measurements on March 25 and May 22, 2003. These measurements, however, are considered ambient temperature conditions for the region and time of year.
$\mathrm{pH}$

The $\mathrm{pH}$ values in the lagoon water ranged from 7.5 to 8.6 units (normal range for seawater is 7.5 to 8.5), with temporal, not spatial, within-station variation. Top and bottom values within stations were similar with no vertical stratification. The lowest value (about 7.5) occurred during July 15, 2003, and the highest value (about 8.6) occurred during May 7, 2003 (appendix 1). The mean lagoon $\mathrm{pH}$ values ranged between 8.1 and 8.2 units, but the mean $\mathrm{pH}$ was slightly lower in the channel. In the channel, the mean $\mathrm{pH}$ for morning measurements was 7.7 and the mean $\mathrm{pH}$ for afternoon measurements was 7.9. Eutrophic waters, with their accelerated primary productivity, commonly experience wide diurnal variations in $\mathrm{pH}$ values.

Variations of $\mathrm{pH}$ between individual sample runs can be expected where primary or community biological productivity is substantial. During daylight hours, when primary productivity is high, dissolved carbon dioxide is captured during photosynthesis, thus, $\mathrm{pH}$ can be expected to rise. During darkness, cellular respiration keeps releasing carbon dioxide into the waters causing a decrease of the $\mathrm{pH}$ (fig. 8). The Laguna de Las Salinas water $\mathrm{pH}$ complied with the PREQB standard of 7.3 to 8.5 units.

\section{Dissolved Oxygen}

The absolute concentration of dissolved oxygen in an aquatic system is controlled primarily by physical variables such as water temperature, barometric pressure, salinity, and by photosynthetic activity. In the presence of high photosynthetic activity, diurnal concentrations of oxygen increase monotonically from lower in the morning to higher concentrations in the late afternoon. Therefore, diurnal variations in dissolved oxygen concentration can be used to estimate the extent of photosynthetic activity. Monthly dissolved oxygen concentration measurements can be used to evaluate water quality in terms of pre-established standards and to help establish longer-term trends.

Monthly dissolved oxygen concentrations at the Laguna de Las Salinas indicate that the variation was lowest at stations 2 and 4 located near the center of the lagoon. The dissolved oxygen concentrations ranged from 5.5 to 7.6 milligrams per liter (mg/L) at station 2 (oxygen saturation values of about 95 and 120 percent, respectively). At station 4, concentrations ranged from 5.4 to $7.6 \mathrm{mg} / \mathrm{L}$, which represent oxygen saturation values of about 93 and 101 percent, respectively.

The largest monthly variations in dissolved oxygen concentration occurred at stations 1,6 , and 8 located along the eastern, southern, and western shorelines of the lagoon, respectively. Concentrations ranged from 2.8 to $6.9 \mathrm{mg} / \mathrm{L}$ at station 1; from 3.8 to $7.5 \mathrm{mg} / \mathrm{L}$ at station 6; and from 3.6 to 7.5 $\mathrm{mg} / \mathrm{L}$ at station 8 . At station 1 (eastern shoreline), the oxygen saturation values ranged from 38 to 90 percent; at station 6 (southern shoreline), the oxygen saturation values ranged from 65 to 99 percent; and at station 8 (western shoreline), the oxygen saturation values ranged from 59 to 119 percent. 


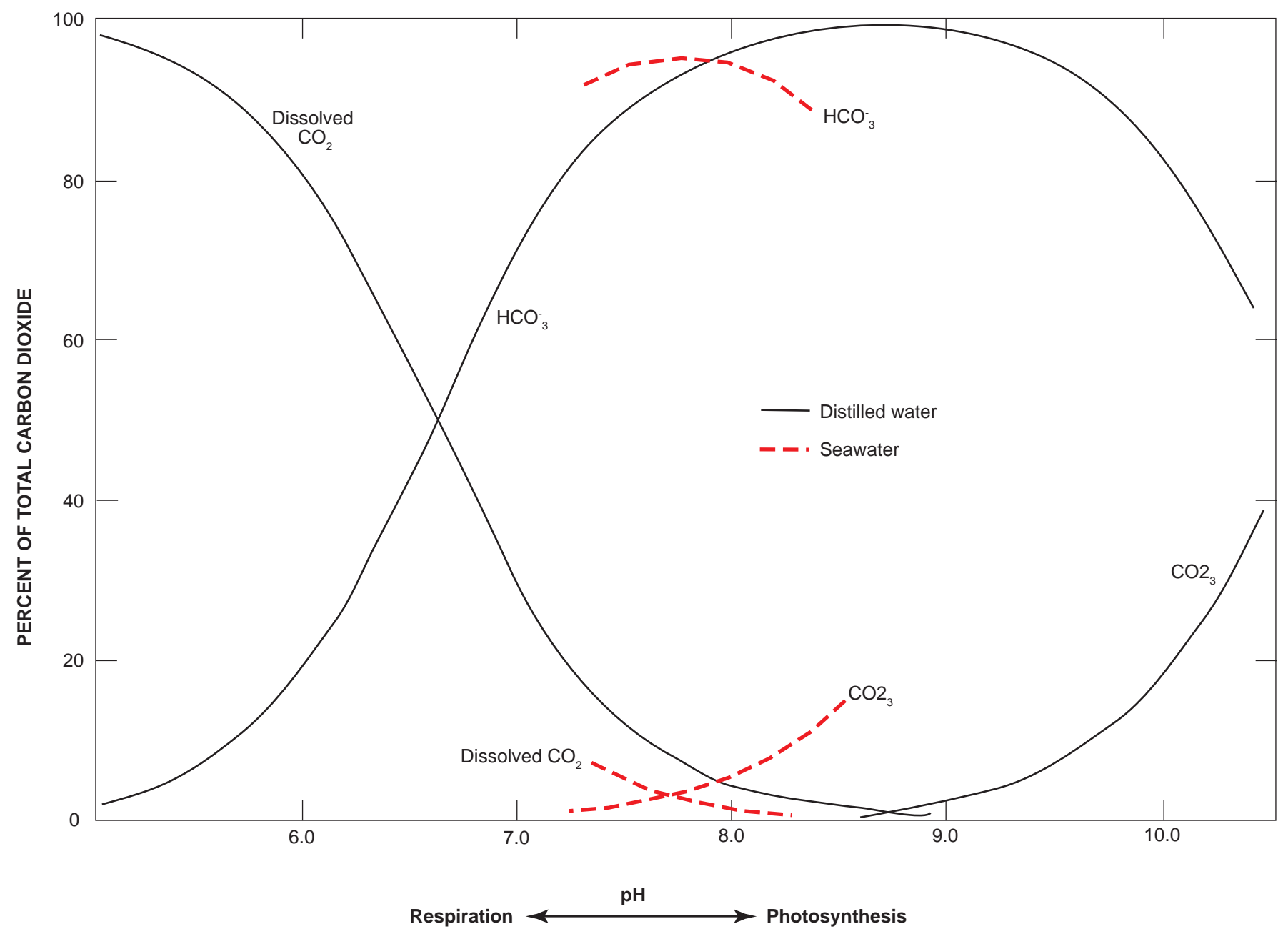

Figure 8. Percentages of dissolved carbon dioxide $\left(\mathrm{CO}_{2}\right)$, bicarbonate ion $\left(\mathrm{HCO}_{3}\right)$, and carbonate ion $\left(\mathrm{CO}_{3}\right)$ as function of $\mathrm{pH}$ at $0^{\circ} \mathrm{C}$.

Dissolved oxygen concentration measurements in the channel (station 3) were generally different than in the lagoon. In general, concentrations during flood tides were lower than during ebb tides (appendix 1). Early morning dissolved oxygen measurements during flood tides are indicative of the dissolved oxygen concentrations of seawater entering the lagoon without the effect of substantial water oxygenation by the wind. These concentrations ranged from 4.3 to $5.8 \mathrm{mg} / \mathrm{L}$ with four measurements less than $5.0 \mathrm{mg} / \mathrm{L}$. Dissolved oxygen saturation ranging from 68 to 73 percent (mean 71 percent), indicates high oxygen demand of nearshore coastal bed sediments and/or high respiration rates of benthic organisms. During ebb tides, dissolved oxygen concentrations were higher, ranging from 6.4 to $10.7 \mathrm{mg} / \mathrm{L}$ (oxygen saturation of about 110 to 165 percent). Dissolved oxygen supersaturation is typical of eutrophic water bodies (Wetzel, 2001). Photosynthetic organisms begin producing oxygen at sunrise, increasing primary productivity and dissolved oxygen concentration as sunlight intensifies. In the afternoon, during ebb tide flow, large quantities of dissolved oxygen are exported to the sea through the channel (station 3). The dissolved oxygen concentrations in the lagoon and channel were generally greater than the PREQB standard of $5.0 \mathrm{mg} / \mathrm{L}$. At stations 1, 5, and 8, however, several readings were below the standard during the morning, when the effect of photosynthesis is negligible and respiration rates are near the daily maximum. 


\section{Specific Conductance}

Specific conductance is a measure of the capacity of water (or other substance) to conduct an electrical current, and is expressed as microsiemens per centimeter $(\mu \mathrm{S} / \mathrm{cm})$ at $25^{\circ} \mathrm{C}$. Specific conductance is a function of the types and quantities of dissolved substances and can be used for approximating the dissolved-solids concentration of the water. Commonly, the concentration of dissolved solids (in milligrams per liter) is 55 to 75 percent of the specific conductance in microsiemens (Díaz and others, 2004).

Measurements of specific conductance (at $25^{\circ} \mathrm{C}$ ) in the Laguna de Las Salinas ranged from 21,000 to $76,000 \mu \mathrm{S} / \mathrm{cm}$. Temporal variation, but not spatial variation of specific conductance was observed within the lagoon. The lowest specific conductance values were measured in November 2003, coinciding with high rainfall/runoff, and the highest values were measured in February 2003.

Some vertical stratification was observed at stations 2,4 , and 7 , where top water column values were about 30 percent less than bottom water column values (mean value about 20,000 $\mu \mathrm{S} / \mathrm{cm}$ near the top and mean about 30,000 $\mu \mathrm{S} / \mathrm{cm}$ near the bottom). The remaining lagoon sites did not show vertical stratification. Because the ocean tide level was about $10 \mathrm{~cm}$ above mean sea level, the higher specific conductance values in the center of the lagoon initially were thought to be from a seawater plume brought in by the flood tide. Flow data collected during this particular sampling (ebb tide flow), however, as well as specific conductance data at the channel (same low values of the other stations) indicated that this was not the case.

Measurements indicated that salty water, being denser and heavier that freshwater, formed a bottom lens in the center of the lagoon. Temperature at the same stations (2, 4, and 7) also indicated a vertical stratification $\left(27^{\circ} \mathrm{C}\right.$ at the top and $29.7^{\circ} \mathrm{C}$ at the bottom). Stratification was absent during measurements obtained in the afternoon presumably because of mixing caused by the wind. The PREQB has no established standards for specific conductance in saline lagoons.

\section{Salinity}

Salinity values were determined indirectly, based on the specific conductance measurements. Salinity is linearly correlated with specific conductance by the relation described in Clesceri and others (1998). Salinity values in the Laguna de Las Salinas exhibited temporal, not spatial variations, with minimal vertical stratification. The highest salinity values were determined on January, February, and August 2003 measurements. The lowest values were determined during October and November 2003. In general, salinity values were higher than the normal for south coast seawater values (about 40 ppt). Salinity was as high as 53 ppt in February 2003 at all sites (excluding the channel during flood-tide flows), and about 50 ppt in August 2003 at all sites (excluding the channel during flood-tide flows). The lowest values were determined in
November 2003 at all sites (excluding the channel during floodtide flows), about 11 ppt or 72 percent below that of the south coast seawater.

\section{Secchi Disk Water Transparency}

Water transparency is a physical property of water that is important ecologically and recreationally. Ecologically, water transparency influences sunlight penetration, and thus, photosynthetic activity. Recreationally, water transparency is an aesthetic characteristic. Water transparency and light penetration can be reduced by natural factors, such as inorganic particulate matter, plankton biomass, and humic and fulvic acids produced from decomposing organic matter.

The water transparency of the Laguna de Las Salinas was measured using a Secchi disk. The Secchi disk has been modified over time and today the most commonly used is about $20 \mathrm{~cm}$ in diameter, made of metal or plastic, and provides a means for determining the limit of visibility based on contrast. The upper surface of the Secchi disk is divided into four quadrants that are alternate black and white. The disk is lowered into the water until it disappears from view at which the depth is recorded. Visibility in water is roughly twice the Secchi depth, because light must travel twice through a water column before it is seen. Biologists consider the depth of the euphotic zone, the upper layer of a water body into which enough light penetrates to permit growth of green plants and algae, roughly three times the measured transparency.

Secchi disk transparency of the Laguna de Las Salinas was generally low compared to the lagoon mean water depth of about $60 \mathrm{~cm}$, with transparencies ranging between 25 and 84 $\mathrm{cm}$, and a mean depth of $40 \mathrm{~cm}$. Only once did the Secchi disk transparency reach the bottom of the lagoon (January 2003). Based on the biologists concept of the euphotic zone, light penetration in the Laguna de Las Salinas should consistently reach the lagoon's bottom allowing vegetative growth on the substrate. As with other physical properties, the Secchi disk transparency showed temporal variations, but no spatial or vertical variations. The highest transparency was recorded in January 2003 at station 2, when visibility reached the lagoon's bottom $(84 \mathrm{~cm})$. The lowest Secchi disk transparency $(25 \mathrm{~cm})$ was recorded on two occasions during the study throughout the lagoon (September and October 2003). The PREQB has no established standards for transparency. 


\section{Water Chemical Properties}

The water chemical properties determined at the Laguna de Las Salinas were nutrients, such as nitrogen and phosphorus, organic carbon, and chlorophyll $a$ and $b$ concentrations.

\section{Nutrients}

Nutrients are elements and compounds essential to plant and animal life (Hutchinson, 1973). Nitrogen (N) and phosphorus (P) compounds are considered the most important in the aquatic ecosystems. Natural waters can become nutrient enriched from organic matter decay, by autotrophic or heterotrophic processes, and by runoff. Human and other animals activities, as well as poor soil conservation practices can increase nutrient inputs to natural waters. Several chemical species of nitrogen such as ammonium, nitrites, nitrates, as well as orthophosphorus, are the primary anthropogenic contaminants related directly to eutrophication. Excessive concentrations of these constituents can lead to increased densities of planktonic and benthic algae, and substantial daily variations in dissolved oxygen concentrations and of $\mathrm{pH}$ (Webb and Gómez-Gómez, 1997).

Nitrogen and phosphorus compounds were sampled on a nearly monthly basis at station 4 , located in the center of the Laguna de Las Salinas (fig. 7), from February 2003 to March 2004. During every other sampling, nutrients were obtained for both total and dissolved concentration determinations. The nitrogen species analyzed were ammonium, nitrate, nitrite, and organic nitrogen (table 4). The phosphorus species analyzed were phosphorus, orthophosphate, and hydrolyzable phosphorus (table 5). All nutrient samples were analyzed at the NWQL

Total nitrogen concentrations ranged from 1.20 to 2.62 $\mathrm{mg} / \mathrm{L}$, with a mean concentration of $1.91 \mathrm{mg} / \mathrm{L}$. The highest concentrations, ranging from 2.11 to $2.62 \mathrm{mg} / \mathrm{L}$, occurred from May to September 2003 (table 4). Dissolved nitrogen concentration ranged from 0.62 to $1.42 \mathrm{mg} / \mathrm{L}$, with a mean concentration of $1.03 \mathrm{mg} / \mathrm{L}$. Total nitrogen concentrations in the Laguna de Las Salinas are well below the PREQB standard of $5.0 \mathrm{mg} / \mathrm{L}$.

Table 4. Total and dissolved nitrogen species concentration by collection date at station 4, from February 2003 to March 2004.

[N, nitrogen; $\mathrm{NH}_{4}+$, ammonium nitrogen; $\mathrm{NO}_{3^{-}}$, nitrate nitrogen; $\mathrm{NO}_{2^{-}}$, nitrite nitrogen; Diss., dissolved; ---, not sampled; r; <, less than; concentrations in milligrams per lite]

\begin{tabular}{|c|c|c|c|c|c|c|c|c|c|c|c|}
\hline Collection date & $\begin{array}{c}\text { Total } \\
\text { organic } \\
\mathrm{N}\end{array}$ & $\begin{array}{l}\text { Total } \\
\mathrm{NH}_{4}^{+}\end{array}$ & $\begin{array}{l}\text { Total } \\
\mathrm{NO}_{2}^{-}\end{array}$ & $\begin{array}{l}\text { Total } \\
\mathrm{NO}_{2}-\end{array}$ & Total N & $\begin{array}{c}\text { Diss. } \\
\text { organic } \\
\mathrm{N}\end{array}$ & $\begin{array}{l}\text { Diss. } \\
\mathrm{NH}_{4}^{+}\end{array}$ & $\begin{array}{l}\text { Diss. } \\
\mathrm{NO}_{3}^{-}\end{array}$ & $\begin{array}{l}\text { Diss. } \\
\mathrm{NO}_{2-}^{-}\end{array}$ & $\begin{array}{c}\text { Diss. } \\
\mathrm{N}\end{array}$ & $\begin{array}{c}\text { Diss./total } \\
\text { N ratio, } \\
\text { in } \\
\text { percent }\end{array}$ \\
\hline February 25, 2003 & 1.66 & 0.04 & $<0.02$ & 0.02 & 1.70 & 1.18 & $<0.02$ & $<0.02$ & 0.01 & 1.19 & 70 \\
\hline March 25 & 1.55 & 0.05 & $<0.02$ & 0.01 & 1.61 & --- & --- & --- & & & \\
\hline May 7 & 1.77 & 0.03 & $<0.02$ & 0.01 & 1.81 & 1.19 & 0.01 & $<0.02$ & $<0.01$ & 1.20 & 66 \\
\hline May 22 & 2.45 & 0.05 & $<0.02$ & 0.01 & 2.51 & --- & --- & --- & & & \\
\hline July 15 & 2.35 & 0.05 & $<0.02$ & 0.02 & 2.42 & 0.89 & 0.01 & $<0.02$ & $<0.01$ & 0.90 & 37 \\
\hline August 13 & 2.03 & 0.07 & $<0.02$ & 0.01 & 2.11 & --- & --- & --- & & & \\
\hline September 17 & 2.52 & 0.08 & $<0.02$ & 0.02 & 2.62 & 1.37 & 0.03 & 0.01 & 0.01 & 1.42 & 54 \\
\hline October 15 & 1.73 & 0.07 & $<0.02$ & 0.01 & 1.81 & --- & --- & --- & & & \\
\hline November 25 & 1.15 & 0.05 & $<0.02$ & $<0.01$ & 1.20 & 0.58 & 0.02 & $<0.02$ & $<0.01$ & 0.62 & 51 \\
\hline December 17 & 1.56 & 0.04 & $<0.02$ & $<0.01$ & 1.60 & --- & --- & --- & & & \\
\hline January 15, 2004 & 1.97 & 0.03 & $<0.02$ & $<0.01$ & 2.00 & 0.79 & 0.01 & $<0.02$ & $<0.01$ & 0.80 & 40 \\
\hline February 5 & 1.44 & 0.06 & $<0.02$ & $<0.01$ & 1.50 & --- & --- & --- & & & \\
\hline March 18 & 1.96 & 0.04 & $<0.02$ & $<0.01$ & 2.00 & 1.09 & 0.01 & $<0.02$ & $<0.01$ & 1.10 & 55 \\
\hline Average & 1.86 & 0.05 & $<0.02$ & $<0.01$ & 1.91 & 1.01 & 0.01 & $<0.02$ & $<0.01$ & 1.03 & 53 \\
\hline
\end{tabular}


Table 5. Total and dissolved phosphorus species concentration by collection date at station 4, from February 2003 to March 2004.

[P, phosphorus; Diss., dissolved; ---, not sampled; <, less than; concentrations in milligrams per liter; all values expressed as P]

\begin{tabular}{lcccccc}
\hline \multicolumn{1}{c}{ Collection date } & Total P & $\begin{array}{c}\text { Ortho- } \\
\text { phosphate }\end{array}$ & $\begin{array}{c}\text { Hydrolyzable } \\
\text { phosphorus }\end{array}$ & Dissolved P & $\begin{array}{c}\text { Diss. ortho- } \\
\text { phosphate }\end{array}$ & $\begin{array}{c}\text { Diss./total P } \\
\text { ratio, in } \\
\text { percent }\end{array}$ \\
\hline February 25, 2003 & 0.04 & 0.03 & 0.01 & 0.04 & 0.03 & 100 \\
March 25 & 0.04 & 0.04 & 0.00 & --- & --- & --- \\
May 7 & 0.05 & 0.03 & 0.02 & 0.02 & 0.02 & 40 \\
May 22 & 0.05 & 0.04 & 0.01 & --- & --- & --- \\
July 15 & 0.06 & 0.04 & 0.02 & 0.04 & 0.03 & 67 \\
August 13 & 0.05 & 0.04 & 0.01 & --- & --- & --- \\
September 17 & 0.04 & 0.03 & 0.01 & 0.02 & 0.02 & 50 \\
October 15 & 0.05 & 0.04 & 0.01 & --- & --- & --- \\
November 25 & 0.02 & 0.02 & 0.00 & 0.02 & 0.01 & 100 \\
December 17 & 0.04 & 0.02 & 0.02 & --- & -- & --- \\
January 15, 2004 & 0.03 & 0.03 & $<0.01$ & 0.02 & 0.01 & 67 \\
February 5 & 0.04 & 0.02 & 0.02 & --- & -- & -- \\
March 18 & 0.04 & 0.03 & 0.01 & 0.02 & 0.01 & 50 \\
\hline \multicolumn{1}{c}{ Average } & 0.04 & 0.03 & 0.01 & 0.03 & 0.02 & 68 \\
\hline
\end{tabular}

Most of the nitrogen (96 percent) found in the Laguna de Las Salinas was in the form of organic nitrogen. Concentrations ranged from 1.15 to $2.52 \mathrm{mg} / \mathrm{L}$ as $\mathrm{N}$, with over 50 percent occurring in the dissolved form. Ammonia concentrations ranged from 0.03 to $0.08 \mathrm{mg} / \mathrm{L}$ as $\mathrm{N}$ or less than 3 percent of the total nitrogen available. The other nitrogen species, nitrate and nitrite were found in concentrations of $0.02 \mathrm{mg} / \mathrm{L}$ as $\mathrm{N}$ or less, or about 1 percent of the total nitrogen available in most of the samples.

The high proportion of the low oxidation states of nitrogen such as organic nitrogen and ammonia, to the high oxidation states of nitrogen such as nitrate and nitrite, could indicate frequent inputs of the former into the lagoon. In the absence of regular stream inflow to the lagoon and the relatively shortduration runoff episodes during the study period, the sources of nitrogen are probably internal (biological metabolism). The high proportion of organic nitrogen compared to the other nitrogen forms, and the high rates of phytoplankton and benthic activities also support this.

Total phosphorus concentrations in the Laguna de Las Salinas were relatively low and ranged from 0.02 to $0.06 \mathrm{mg} / \mathrm{L}$ as P; the highest concentrations generally occurred from May to August 2003 (table 5). Mean concentration was $0.04 \mathrm{mg} / \mathrm{L}$. Most of the phosphorus (75 percent) was in the form of total orthophosphate, with concentrations ranging from 0.02 to 0.04 $\mathrm{mg} / \mathrm{L}$ as $\mathrm{P}$; over 60 percent of the total orthophosphate was present in the dissolved form (table 5). Hydrolyzable phosphorus concentrations ranged from below detection to 0.02 $\mathrm{mg} / \mathrm{L}$. The total phosphorus concentrations in the Laguna de Las Salinas were well below the PREQB standard of $1.0 \mathrm{mg} / \mathrm{L}$.

Redfield and others (1963) found that the atomic ratio of carbon $(\mathrm{C})$, nitrogen $(\mathrm{N})$, and phosphorus $(\mathrm{P})$ are related generally by the ratio of $\mathrm{C}_{106}: \mathrm{N}_{16}: \mathrm{P}_{1}$ in planktonic tissue (Redfield's ratio). Because carbon is the more abundant element of the three and is recycled by so many natural and biological processes unlike nitrogen, the Redfield ratio can be simplified to the total nitrogen to total phosphorus ratio (TN/TP). This ratio can be used to determine the potential for phytoplankton and plant growth in natural waters. According to Vollenweinder (1968), TN/TP ratios exceeding 15 indicate that phosphorus is the limiting factor for phytoplankton and aquatic plant growth. The TN/TP ratio in the Laguna de Las Salinas ranged from 36 to 67 , with a mean of 47 , indicating that phosphorus was the limiting factor in primary productivity in the Laguna de Las Salinas. 


\section{Organic Carbon}

Total and dissolved organic carbon were sampled on a nearly monthly basis in the Laguna de Las Salinas at stations 2 and 7 located near the center of the lagoon (fig. 7). For every other sampling, organic carbon was obtained for analyses of both total and dissolved concentrations. There were no significant variations between the concentrations at the two sites during the study, thus, mean concentration for the two sites are given for each sample date (table 6). The mean concentration of total organic carbon for the two sites ranged from 12.0 to $19.0 \mathrm{mg} / \mathrm{L}$ (table 6 ) with the greater portion, almost 80 percent, found in the dissolved state (from 9.4 to $15.0 \mathrm{mg} / \mathrm{L}$ ). The PREQB does not have standards for organic carbon concentrations.

\section{Chlorophyll $a$ and $b$}

Chlorophyll $a$ and $b$ are the principal photosynthetic pigments in vascular plants and algae. Chlorophyll $a$ is the primary photosynthetic pigment of all oxygen-producing organisms. Chlorophyll $b$, although common in higher plants, is present only in green algae, euglenophytes, and other minor

Table 6. Total and dissolved organic carbon concentration average of stations 2 and 7 by collection date, from February 2003 to March 2004. Refer to figure 7 for locations.

[concentrations in milligrams per liter; ---, not sampled]

\begin{tabular}{|c|c|c|c|}
\hline Collection date & $\begin{array}{c}\text { Total } \\
\text { organic } \\
\text { carbon }\end{array}$ & $\begin{array}{c}\text { Dissolved } \\
\text { organic } \\
\text { carbon }\end{array}$ & $\begin{array}{l}\text { Dissolved } \\
\text { to total } \\
\text { ratio, in } \\
\text { percent }\end{array}$ \\
\hline February 25, 2003 & 16.0 & 12.0 & 75 \\
\hline March 25 & 14.0 & --- & --- \\
\hline May 7 & 13.0 & 12.0 & 92 \\
\hline May 22 & 18.0 & --- & --- \\
\hline July 15 & 15.0 & 12.0 & 75 \\
\hline August 13 & 16.0 & --- & --- \\
\hline September 17 & 19.0 & 15.0 & 75 \\
\hline October 15 & 16.0 & --- & --- \\
\hline November 25 & 12.0 & 9.4 & 72 \\
\hline December 17 & 14.0 & --- & --- \\
\hline January 15, 2004 & 14.0 & 11.0 & 79 \\
\hline February 5 & 15.0 & --- & --- \\
\hline March 18 & 12.0 & 9.9 & 82 \\
\hline Average & 15.0 & 12.0 & 79 \\
\hline
\end{tabular}

groups. Chlorophyll $a$ and $b$ were sampled at stations 2 and 7 near the center of the Laguna de Las Salinas (fig. 7). There were no significant variations between the concentration at the two sites during the study, thus, mean concentration for the two sites are given for each sampling date (table 7).

The average concentration of chlorophyll $a$ for the two sites ranged from about 3.6 to 22.5 micrograms per liter ( $\mu \mathrm{g} / \mathrm{L})$. The highest concentrations were found in November and December 2003; the lowest concentration occurred during September 2003 (table 7). The highest chlorophyll concentrations occurred when salinity was at its lowest (about $13 \mathrm{ppt}$, near the water surface at both stations); the opposite occurred when salinity was near $48 \mathrm{ppt}$ at both stations. Primary productivity in the lagoon is likely "inhibited" during periods of excess evaporation and increased salinities. Hypersaline waters have a high osmotic pressure, reducing water uptake by photosynthetic organisms, and lesser availability of certain micronutrients, especially iron (F. Gómez-Gómez, U.S. Geological Survey, oral commun., 2004). Chlorophyll $b$ concentration was below the laboratory detection limit of 0.10 $\mu \mathrm{g} / \mathrm{L}$, during most of the study except during May 22 and October 15, 2003, with average concentrations of 0.24 and 1.69 $\mu \mathrm{g} / \mathrm{L}$, respectively (table 7 ).

Table 7. Chlorophyll $a$ and $b$ concentration average of stations 2 and 7 by collection date, from February 2003 to March 2004.

[concentrations in micrograms per liter; ---, not determined; <, less than]

\begin{tabular}{lcc}
\hline \multicolumn{1}{c}{ Collection date } & Chlorophyll $a$ & Chlorophyll $b$ \\
\hline February 25, 2003 & 9.76 & $<0.10$ \\
March 25 & 14.14 & $<0.10$ \\
May 7 & 16.55 & $<0.10$ \\
May 22 & 18.59 & 0.24 \\
July 15 & 17.36 & $<0.10$ \\
August 13 & 8.55 & $<0.10$ \\
September 17 & 3.56 & $<0.10$ \\
October 15 & 6.56 & 1.69 \\
November 25 & 20.95 & $<0.10$ \\
December 17 & 22.46 & $<0.10$ \\
January 15, 2004 & 18.74 & $<0.10$ \\
February 5 & 9.07 & $<0.10$ \\
March 18 & 8.22 & $<0.10$ \\
\hline Average & 13.42 & --- \\
\hline
\end{tabular}




\section{Biological Characteristics}

The biological characteristics of the Laguna de Las Salinas determined as part of the study were the primary productivity, phytoplankton biomass, and fecal bacteria concentration.

\section{Primary Productivity}

The primary productivity of an ecosystem is defined as the rate at which new organic matter is created by photosynthesis (or chemosynthesis), and is expressed as the production of organic matter per unit of volume (or surface area) per unit of time. The principal primary producers in aquatic ecosystems include phytoplankton, periphyton, and macrophytes. Phytoplanktonic production represents a major synthesis of organic matter in aquatic systems, however, primary productivity by periphyton and macrophytes can be substantial. The primary productivity is summarized by the universal equation:

$$
6 \mathrm{CO}_{2}+12 \mathrm{H}_{2} \mathrm{O} \underset{\text { photosynthesis }}{\text { light }}>\mathrm{C}_{6} \mathrm{H}_{12} \mathrm{O}_{6}+6 \mathrm{H}_{2} \mathrm{O}+6 \mathrm{O}_{2}
$$

The importance of the primary productivity of an estuarine system lies in that primordial food is created supporting the biological food chain. The primary productivity has three processes that influence the net organic matter created:

1. Net productivity $(\mathrm{Pn})$ - the net production of organic matter, or stored energy minus the losses per selected time interval. This process involves photosynthetic organisms only.

2. Respiration (R) - the amount of oxygen consumed by metabolic processes. This process involves all community organisms.

3. Gross productivity (Pg) - the observed change in biomass, plus all predatory and non-predatory losses per selected time interval. This process involves all community organisms and is the sum of net productivity plus respiration.

In estimating primary productivity rates, respiration and gross productivity rates are also determined. The most straight forward and inexpensive method for estimating primary productivity in water bodies is the light (translucent) and dark oxygen bottles method (Clesceri and others, 1998). Because this technique was used for analysis of net primary productivity by phytoplankton (water column) to determine the entire aquatic net community primary productivity (phytoplankton, periphyton, and macrophytes), a diel study was also conducted.

Periphyton and macrophytes net primary productivity can then be expressed as the community net primary productivity minus the phytoplankton net primary productivity. Both methods were applied in the Laguna de Las Salinas, and although discussed separately here, the results of both are integrated into a comprehensive discussion later.

To better understand the discussion of the primary productivity results, a brief definition of some biological terms is included:

1. Plankton - organisms that float through the water column, generally not able to swim and not attached to any substrate. Plankton can be divided into phytoplankton and zooplankton.

2. Phytoplankton - the plant and algae component of the plankton; the primary producers.

3. Zooplankton - animal component of the plankton that feed on phytoplankton and other zooplankton; the primary consumers.

4. Periphyton - the assemblage of microorganisms attached to and living upon submerged solid surfaces, primarily consisting of algae, fungi, and bacteria.

5. Macrophytes - macroscopic plants in the aquatic environment and commonly rooted vascular plants.

6. Benthos - plants, animals, algae, and other organisms living on the bottom of a body of water.

Natural systems are affected by many factors causing rapid, frequent, and irregular changes such that only average rates can be determined in a typical environment. The annual time period, therefore, is the most meaningful interval in comparative quantitative analyses of material and energy fluxes at population, community, and ecosystems levels (Wetzel, 2001).

\section{Light and Dark Bottle Primary Productivity, Community Respiration, and Community Gross Productivity}

Light and dark bottle primary productivity measurements were made to determine the net primary productivity by phytoplankton. At roughly monthly intervals, productivity measurements were made at stations 2 and 7 near the center of the Laguna de Las Salinas (fig. 7) by incubation of lagoon water in light and dark dissolved oxygen bottles. Incubation was typically between 8:00 a.m. and 12:00 p.m. The initial concentration of dissolved oxygen prior to incubation was determined using the Winkler titration method (Clesceri and others, 1998). At these sites, an aluminum rack holding four bottles, two contiguous light bottles and two contiguous dark bottles, was deployed (Clesceri and others, 1998). The samples of lagoon water were incubated at the depths from which they were collected for at least 3 hours. After incubation, the bottles were removed and their dissolved oxygen concentration was determined by titration. The initial dissolved oxygen concentration was expected to decrease in the dark bottle by respiration, and was expected to increase in the light bottle by photosynthesis. The oxygen production and respiration results, therefore, can be expressed as: 
Gross productivity $(\mathrm{Pg})=\mathrm{OL}-\mathrm{OD}$;

Net productivity $(\mathrm{Pn})=\mathrm{OL}-\mathrm{OI}$; and

Respiration (R) = OI - OD,

where, OL is the light bottle, dissolved oxygen concentration at the end of the incubation period; OD is the dark bottle, dissolved oxygen concentration at the end of the incubation period; and $\mathrm{OI}$ is the initial dissolved oxygen concentration prior to incubation.

Tables 8 and 9 summarize the primary productivity results at stations 2 and 7, respectively. The dissolved oxygen concentrations shown on tables 8 and 9 represent the average of two titrations for each of the two light bottles and the average of two titrations for each of the two dark bottles, therefore, each individual OL, OI, and OD value presented in tables 8 and 9 is the average of four different titrations.

Using oxygen as a measure of photosynthetic and respiration rates, results of the light-dark primary productivity studies (tables 8 and 9) indicate that the Laguna de Las Salinas plankton community is highly productive. The phytoplankton yielded an average net productivity rate of 0.16 milligrams of oxygen per liter per hour $\left(\mathrm{mgO}_{2} / \mathrm{L}^{-} \mathrm{hr}\right)$, and the plankton yielded an average respiration rate of $0.26 \mathrm{mgO}_{2} / \mathrm{L}^{-} \mathrm{hr}$. The average plankton gross productivity rate was $0.44 \mathrm{mgO}_{2} / \mathrm{L}$ hhr. Multiplying the average net productivity rate by the number of hours where net primary productivity occurred (typically 8 hours based on the diel studies results), gives a daily net productivity of $1.28 \mathrm{mgO}_{2} / \mathrm{L}$, which is equal to a daily net productivity of about 1.28 grams of oxygen per cubic meter $\left(\mathrm{gO}_{2} / \mathrm{m}^{3}\right)$. Using the same reasoning (respiration rates can be assumed to occur throughout a 24-hour period), the daily respiration was $6.24 \mathrm{gO}_{2} / \mathrm{m}^{3}$. The average daily gross productivity was $7.52 \mathrm{gO}_{2} / \mathrm{m}^{3}$. Multiplying the daily net productivity by 0.375 gives an estimation of the net organic carbon produced (Fox, 2000). The Laguna de Las Salinas water column (phytoplankton), therefore, had an estimated daily net organic carbon production of about 0.5 gram per cubic meter $\left(\mathrm{g} / \mathrm{m}^{3}\right)$. Upwelling coastal zones, where nutrient-rich waters move upward by currents and wind, are considered to be highly productive with a primary productivity rate in the range of 0.25 to 0.5 grams of carbon per cubic meter per day (Lecture Notes in Biological Oceanography, 1999). The Laguna de Las Salinas compares well with the upper range of coastal upwelling zones productivity. Based on the estimated water volume of the Laguna de Las Salinas of about 217,000 $\mathrm{m}^{3}$, the lagoon phytoplankton community produced an estimated average of about 108 kilograms of carbon every day, or about 40 metric tons of carbon per year. This organic carbon production is only about 10 percent of the total organic carbon production in the lagoon (about 400 metric tons per year).

\section{Diel Primary Productivity, Community Respiration, and Community Gross Productivity}

Diel studies were conducted in the Laguna de Las Salinas to estimate the community net primary productivity, the respiration rate, and the gross productivity rate. A diel study consists of obtaining measurements of physical and chemical properties, such as $\mathrm{pH}$, temperature, specific conductance, dissolved oxygen, and salinity, which are affected by metabolic processes in a body of water during one complete diurnal cycle. At the Laguna de Las Salinas, diel studies were conducted twice, on May 1 and on October 16, 2003, corresponding to the normal periods of annual low and high tides in the southern coast of Puerto Rico, respectively. The diel method consists of measuring the dissolved oxygen concentration, temperature, and salinity (or conductivity) to define the hourly variation in the saturation levels of dissolved oxygen to calculate the net oxygen production and respiration rates (Odum, 1956).

The first diel study was conducted on May 1, 2003. Data collection began before sunrise, at 5:55 a.m., and continued after sunset, until 7:33 p.m. Measurements were obtained for $\mathrm{pH}$, temperature, specific conductance, dissolved oxygen, and salinity at stations 1, 4, 5, 6 and 8 (fig. 7). Appendix 2 summarizes the dissolved oxygen concentrations at these stations, and figure 9 shows the May 1, 2003, dissolved oxygen data collected for station 4 . Dissolved oxygen concentration and saturation increased steadily from about 6 a.m. reaching maximum from about 3 to 6 p.m., when dissolved oxygen concentration began decreasing and respiration was more evident. Dissolved oxygen data were corrected for diffusion and the net dissolved oxygen rate of change was calculated. Values above zero represent net primary productivity; values below are respiration. The net productivity and respiration were calculated by mathematical integration. The average community net primary productivity was 15.2 grams of oxygen per cubic meter per day $\left(\mathrm{gO}_{2} / \mathrm{m}^{3-} \mathrm{d}\right)$, the average community respiration was $47.1 \mathrm{gO}_{2} / \mathrm{m}^{3^{-}} \mathrm{d}$, and the average community gross productivity was $62.3 \mathrm{gO}_{2} / \mathrm{m}^{3-} \mathrm{d}$ (table 10 ). The results indicate that respiration exceeded net primary productivity by a factor of three.

The Laguna de Las Salinas second diel study was conducted on October 16, 2003. Data collection began before sunrise at 5:42 a.m. and continued through the day to 6:56 p.m., after sunset. Hourly readings of $\mathrm{pH}$, temperature, specific conductance, dissolved oxygen, and salinity were obtained at stations 1, 4, 5, 6, and 8 (fig. 7). Appendix 3 summarizes the dissolved oxygen concentration readings at these stations. The average community net primary productivity was $11.9 \mathrm{gO}_{2} / \mathrm{m}^{3-} \mathrm{d}$, the average community respiration was $71.3 \mathrm{gO}_{2} / \mathrm{m}^{3-} \mathrm{d}$, and the average gross community productivity was $83.2 \mathrm{gO}_{2} / \mathrm{m}^{3-\mathrm{d}}$ (table 11 ). Respiration exceeded net primary productivity by a factor of six. 
Table 8. Primary productivity results at the Laguna de Las Salinas at station 2 obtained by the light and dark bottle method by collection date, from January 2003 to March 2004.

[All dissolved oxygen values are in milligrams per liter; all productivity and respiration rates are in milligrams of oxygen per cubic meter per hour. DO sat., dissolved oxygen saturation; OI, initial oxygen; OL, light bottle oxygen; OD, dark bottle oxygen; GP, gross productivity; NP, net productivity; R, respiration; Ti, initial incubation time; IT, incubation time in hours; ---, not determined]

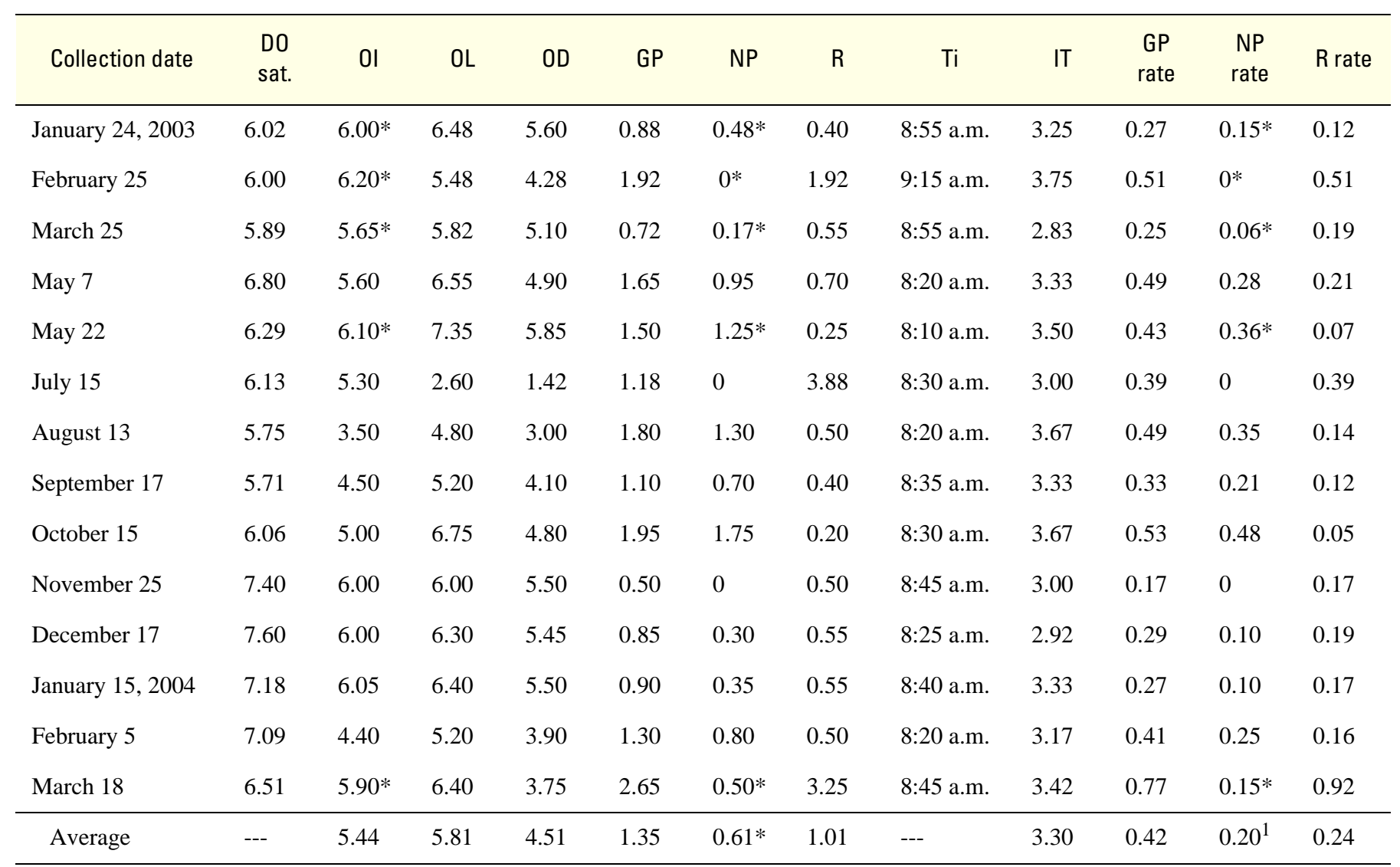

${ }^{1}$ Average was calculated using reliable net productivity rates only.

* OI value at or near saturation; NP not reliable. 
Table 9. Primary productivity results at the Laguna de Las Salinas at station 7 obtained by the light and dark bottle method by collection date, from January 2003 to March 2004.

[All dissolved oxygen values are in milligrams per liter; all productivity and respiration rates are in milligrams of oxygen per cubic meter per hour. DO sat., dissolved oxygen saturation; OI, initial oxygen; OL, light bottle oxygen; OD, dark bottle oxygen; GP, gross productivity; NP, net productivity; R, respiration; Ti, initial incubation time; IT, incubation time in hours; ---, not determined]

\begin{tabular}{|c|c|c|c|c|c|c|c|c|c|c|c|c|}
\hline February 25 & $6.06 *$ & 5.10 & 5.78 & 4.72 & 1.06 & 0.68* & 0.38 & 8:50 a.m. & 3.92 & 0.27 & $0.17^{*}$ & 0.10 \\
\hline March 25 & $5.94 *$ & 6.65 & 4.80 & 3.95 & 2.70 & $0^{*}$ & 2.70 & 8:30 a.m. & 3.17 & 0.27 & $0^{*}$ & 0.27 \\
\hline May 22 & $6.34 *$ & 5.50 & 7.52 & 4.60 & 2.92 & $2.02 *$ & 0.90 & 7:55 a.m. & 4.00 & 0.73 & $0.50 *$ & 0.23 \\
\hline July 15 & 6.13 & 4.70 & 4.55 & 3.00 & 1.55 & 0 & 1.70 & 8:10 a.m. & 3.58 & 0.43 & 0 & 0.43 \\
\hline August 13 & $5.79 *$ & 5.00 & 5.02 & 4.00 & 1.02 & $0.02 *$ & 1.00 & 8:05 a.m. & 3.75 & 0.27 & $0 *$ & 0.27 \\
\hline November 25 & 7.40 & 5.85 & 6.55 & 5.50 & 1.05 & 0.70 & 0.35 & 8:30 a.m. & 3.00 & 0.35 & 0.23 & 0.12 \\
\hline December 17 & 7.60 & 6.40 & 6.70 & 5.80 & 0.90 & 0.30 & 0.60 & 8:05 a.m. & 3.00 & 0.30 & 0.10 & 0.20 \\
\hline January 15, 2004 & $7.18 *$ & 6.20 & 7.25 & 5.65 & 1.60 & $1.05 *$ & 0.55 & 8:20 a.m. & 3.50 & 0.46 & $0.30 *$ & 0.16 \\
\hline February 5 & 7.15 & 4.60 & 4.70 & 3.80 & 0.90 & 0.10 & 0.80 & 8:00 a.m. & 3.75 & 0.24 & 0.03 & 0.21 \\
\hline March 18 & $6.50 *$ & 6.15 & 6.20 & 2.60 & 3.60 & $0.05 *$ & 3.55 & 8:20 a.m. & 3.67 & 0.98 & $0.01 *$ & 0.97 \\
\hline Average & --- & 5.65 & 6.11 & 4.51 & 1.74 & $0.61 *$ & 1.14 & --- & 3.54 & 0.45 & $0.12^{1}$ & 0.28 \\
\hline
\end{tabular}

${ }^{1}$ Average was calculated using reliable net productivity rates only.

* OI value at or near saturation; NP not reliable. 

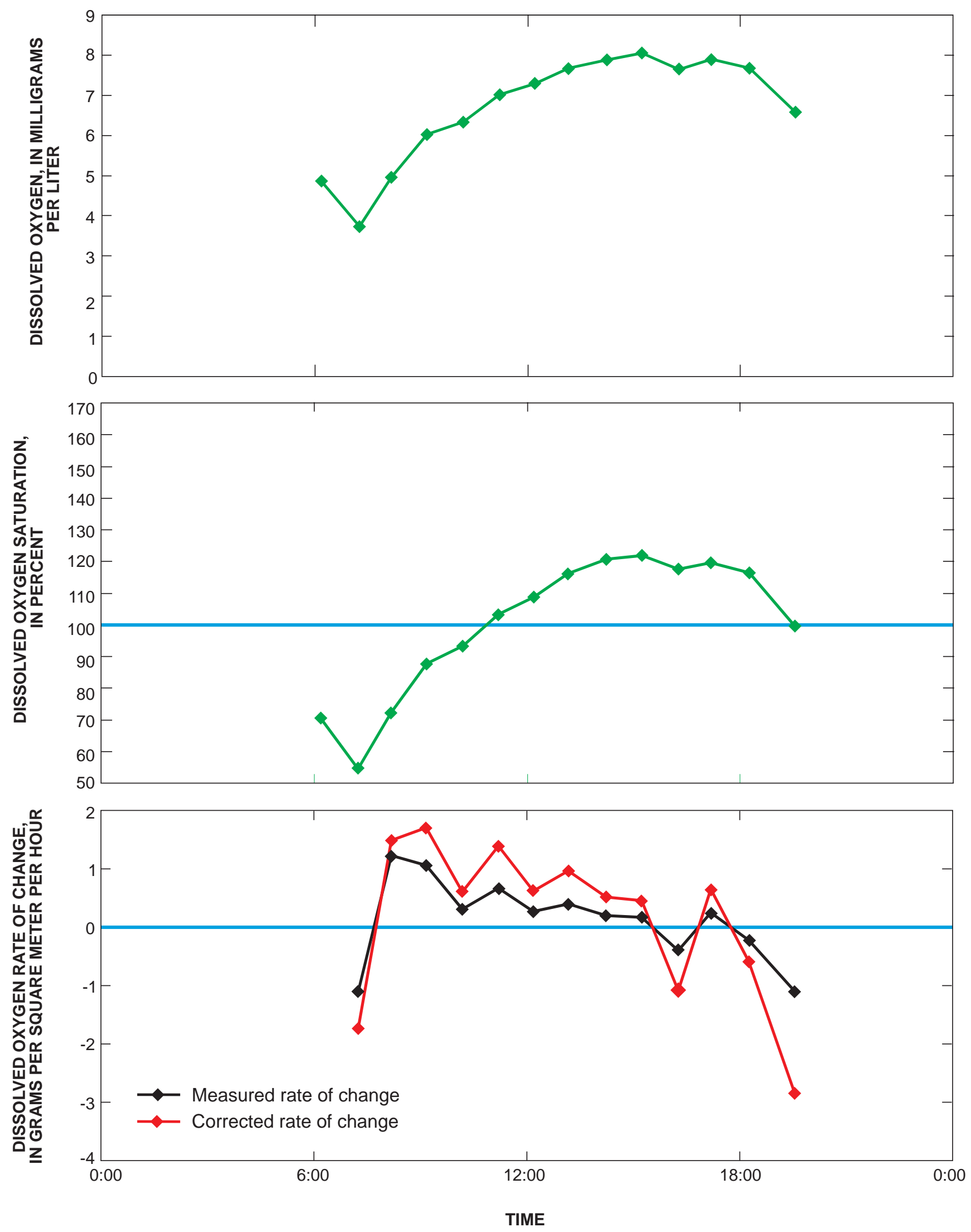

Figure 9. Dissolved oxygen, dissolved oxygen percent saturation, and rate of change curves for May 1, 2003, at station 4 in the Laguna de Las Salinas, Ponce, Puerto Rico. 
Table 10. Primary productivity results for the May 1, 2003, diel study at the Laguna de Las Salinas, Ponce, Puerto Rico.

[All values are in grams of oxygen per cubic meter per day; parenthetical values are in grams of carbon per cubic meter per day. Study began at 5:55 a.m. and ended at 7:33 p.m.; productivity calculated for a 24-hour period]

\begin{tabular}{cccc}
\hline Station number & Net productivity & Respiration & Gross productivity \\
\hline 1 & $8.9(3.3)$ & $35.6(13.4)$ & $44.5(16.7)$ \\
4 & $5.5(2.1)$ & $26.0(9.8)$ & $31.5(11.8)$ \\
5 & $14.2(5.3)$ & $62.0(23.2)$ & $76.2(28.6)$ \\
6 & $15.4(5.8)$ & $41.7(15.6)$ & $57.1(21.4)$ \\
8 & $31.9(12.0)$ & $70.3(26.4)$ & $102.2(38.3)$ \\
\hline Average & $15.2(5.7)$ & $47.1(17.7)$ & $62.3(23.4)$ \\
\hline
\end{tabular}

Table 11. Primary productivity results for the October 16, 2003, diel study at the Laguna de Las Salinas, Ponce, Puerto Rico.

[All values are in grams of oxygen per cubic meter per day; parenthetical values are in grams of carbon per cubic meter per day. Study began at 5:42 a.m. and ended at 6:56 p.m.; productivity calculated for a 24-hour period]

\begin{tabular}{cccc}
\hline Station number & Net productivity & Respiration & Gross productivity \\
\hline 1 & $9.8(3.7)$ & $62.4(23.4)$ & $72.2(27.1)$ \\
4 & $23.0(8.6)$ & $144.5(54.2)$ & $167.5(62.8)$ \\
5 & $5.4(2.0)$ & $41.7(15.6)$ & $47.1(17.7)$ \\
6 & $13.2(5.0)$ & $68.1(25.5)$ & $81.3(30.5)$ \\
8 & $8.1(3.0)$ & $39.9(15.0)$ & $48.0(18.0)$ \\
\hline Average & $11.9(4.5)$ & $71.3(26.7)$ & $83.2(31.2)$ \\
\hline
\end{tabular}


The results for the May 1 and October 16, 2003, diel studies were an average net primary productivity of $13.6 \mathrm{gO}_{2} / \mathrm{m}^{3^{-}} \mathrm{d}$, a community respiration of $59.2 \mathrm{gO}_{2} / \mathrm{m}^{3^{-}} \mathrm{d}$, and a community gross productivity of $72.8 \mathrm{gO}_{2} / \mathrm{m}^{3^{-}} \mathrm{d}$. Net primary productivity was slightly higher during May, whereas respiration was almost twice as high during October and as a result, gross primary productivity was higher during October. Net primary productivity in May could have been enhanced by rainfall runoff occurring in April, which lowered the salinity from about 47 to 26 ppt. Also, concentrations of nutrients in May were higher than in October. Community respiration was more vigorous during October, on average nearly twice as high (71.3 $\left.\mathrm{gO}_{2} / \mathrm{m}^{3^{-}} \mathrm{d}\right)$ than in May $\left(47.1 \mathrm{gO}_{2} / \mathrm{m}^{3^{-}} \mathrm{d}\right)$. Salinity was about 40 ppt in May. It seems that during periods when salinity is greater than or equal to seawater, community respiration exceeds net primary productivity in the Laguna de Las Salinas.

The results of light and dark bottle and diel studies, indicate that periphyton and macrophyte photosynthesis were the predominant form of net primary productivity in the Laguna de Las Salinas. Periphyton and macrophytes produced the greater amount of the oxygen, $12.3 \mathrm{gO}_{2} / \mathrm{m}^{3-} \mathrm{d}$. Approximately $1.3 \mathrm{gO}_{2} / \mathrm{m}^{3-} \mathrm{d}$ was estimated to be produced by the phytoplankton. The average overall net primary productivity, which includes phytoplankton, periphyton, and macrophytes, was $13.6 \mathrm{gO}_{2} / \mathrm{m}^{3^{-}} \mathrm{d}$ or a net organic carbon production of about 400 metric tons per year. The ratio of net primary productivity in the Laguna de Las Salinas is 10 percent by phytoplankton and 90 percent by periphyton and macrophytes.

Respiration rate ascribed to the water column (plankton) averaged about $6.2 \mathrm{gO}_{2} / \mathrm{m}^{3^{-}} \mathrm{d}$; whereas, the respiration rate by all other organisms present in the Laguna de Las Salinas, which include the benthos, fish, and invertebrates, averaged $53.0 \mathrm{gO}_{2} / \mathrm{m}^{3^{-}} \mathrm{d}$ for a total community respiration rate of $59.2 \mathrm{gO}_{2} / \mathrm{m}^{3^{-}} \mathrm{d}$.

Water column organisms (plankton) gross productivity was $7.5 \mathrm{gO}_{2} / \mathrm{m}^{3^{-}} \mathrm{d}$; gross productivity of periphyton and macrophytes averaged $65.2 \mathrm{gO}_{2} / \mathrm{m}^{3^{-}} \mathrm{d}$, for a total gross productivity rate by all organisms living in the Laguna de Las Salinas of $72.8 \mathrm{gO}_{2} / \mathrm{m}^{3^{-}} \mathrm{d}$. Thus, about 90 percent of the gross productivity in the Laguna de Las Salinas is by metabolism of benthic and higher organisms.

At stations 5, 6, and 8, located along the western lithoral zone, the community net and gross productivities were substantially higher during the May measurements. The higher productivity indicates that the algal mats and seagrasses on the western littoral zone of the lagoon are more prolific. On February 17, 2003, when the lagoon water level was considerably low, portions of the bottom of the lagoon were exposed and large areas of the seagrass Ruppia maritima, a halophylic species, were visible. During October, the community net and gross productivity patterns changed. The community net and gross productivities were substantially higher at station 4 (table 10), with a lower rate along the southern littoral, and a very low gross productivity along the northwestern littoral zone.

\section{Phytoplankton Biomass}

Phytoplankton biomass is defined as the mass or weight of photosynthetic organisms present in the water column per unit of area or volume, at a given instant in time (Wetzel, 2001) and is synonymous with phytoplankton standing crop.

Phytoplankton biomass was determined in the Laguna de Las Salinas at the same stations 2 and 7, where light and dark bottle primary productivity measurements were made (fig. 7).

The phytoplankton biomass was determined using the ash-weight/dry-weight ratio method (Clesceri, 1998). Water samples, collected as sequential replicates from the water column at the point from which samples were obtained for the light and dark bottle incubation, were filtered through a glassfiber (borosilicate) filter, refrigerated and sent to the NWQL for analysis. At the laboratory, these filters were dried at $105^{\circ} \mathrm{C}$ overnight, cooled to room temperature, and weighed. The samples were again dried at $60^{\circ} \mathrm{C}$ for several hours and weighed. The difference in weight is reported as the ash-free dry phytoplankton biomass in milligrams per liter.

The average phytoplankton biomass values for the two stations in the Laguna de Las Salinas ranged from 24.05 to $130.0 \mathrm{mg} / \mathrm{L}$. The minimum value was obtained in November 25, 2003, and the highest value was obtained in July 15, 2003 (table 12).

Table 12. Average phytoplankton biomass concentration at the Laguna de Las Salinas, Ponce, Puerto Rico, by collection date, from February 2003 to March 2004.

[All concentrations are in milligrams per liter]

\begin{tabular}{lc}
\hline \multicolumn{1}{c}{ Collection date } & Ash-free dry weight biomass \\
\hline February 25, 2003 & 55.35 \\
March 25 & 39.70 \\
May 7 & 29.20 \\
May 22 & 70.85 \\
July 15 & 130.00 \\
August 13 & 88.00 \\
September 17 & 99.50 \\
October 15 & 77.50 \\
November 25 & 24.05 \\
December 17 & 35.50 \\
January 15, 2004 & 29.75 \\
February 5 & 64.50 \\
March 18 & 31.40 \\
\hline Average & 59.64 \\
\hline
\end{tabular}


Based on the average phytoplankton biomass concentration of $59.64 \mathrm{mg} / \mathrm{L}$ between February 2003 and March 2004 , and an estimated water volume of $217,000 \mathrm{~m}^{3}$, the Laguna de Las Salinas contained a phytoplankton standing crop of about 13 metric tons. The ratio of gross production to biomass $(\mathrm{P} / \mathrm{B})$ is a weighted mean value of biomass growth rates of all individuals in a population (Benke, 1993), and can be used to estimate the turnover rate of organisms giving a general index of the rate of energy flow relative to the biomass. Production to biomass values decrease generally with increase in the trophic level (Benke, 1993).
Based on the average plankton daily gross productivity of $7.5 \mathrm{gO}_{2} / \mathrm{m}^{3}$, the annual plankton gross productivity was calculated as 2,738 $\mathrm{gO}_{2} / \mathrm{m}^{3}$. Using the average annual phytoplankton biomass of $59.64 \mathrm{~g} / \mathrm{m}^{3}$, the $\mathrm{P} / \mathrm{B}$ ratio $(2,738 / 59.64)$ is about 46 , which means that phytoplankton community has a turnover (renewal) rate of about 46 times per year (roughly about once a week). The phytoplankton gross productivity rate correlates generally with the phytoplankton biomass concentration for most months (fig. 10), with the exception of the July 15, September 17, and November 25, 2003, samplings. This indicates that phytoplankton biomass may be a viable, more simple, and relatively inexpensive alternate method for use in monitoring gross productivity.

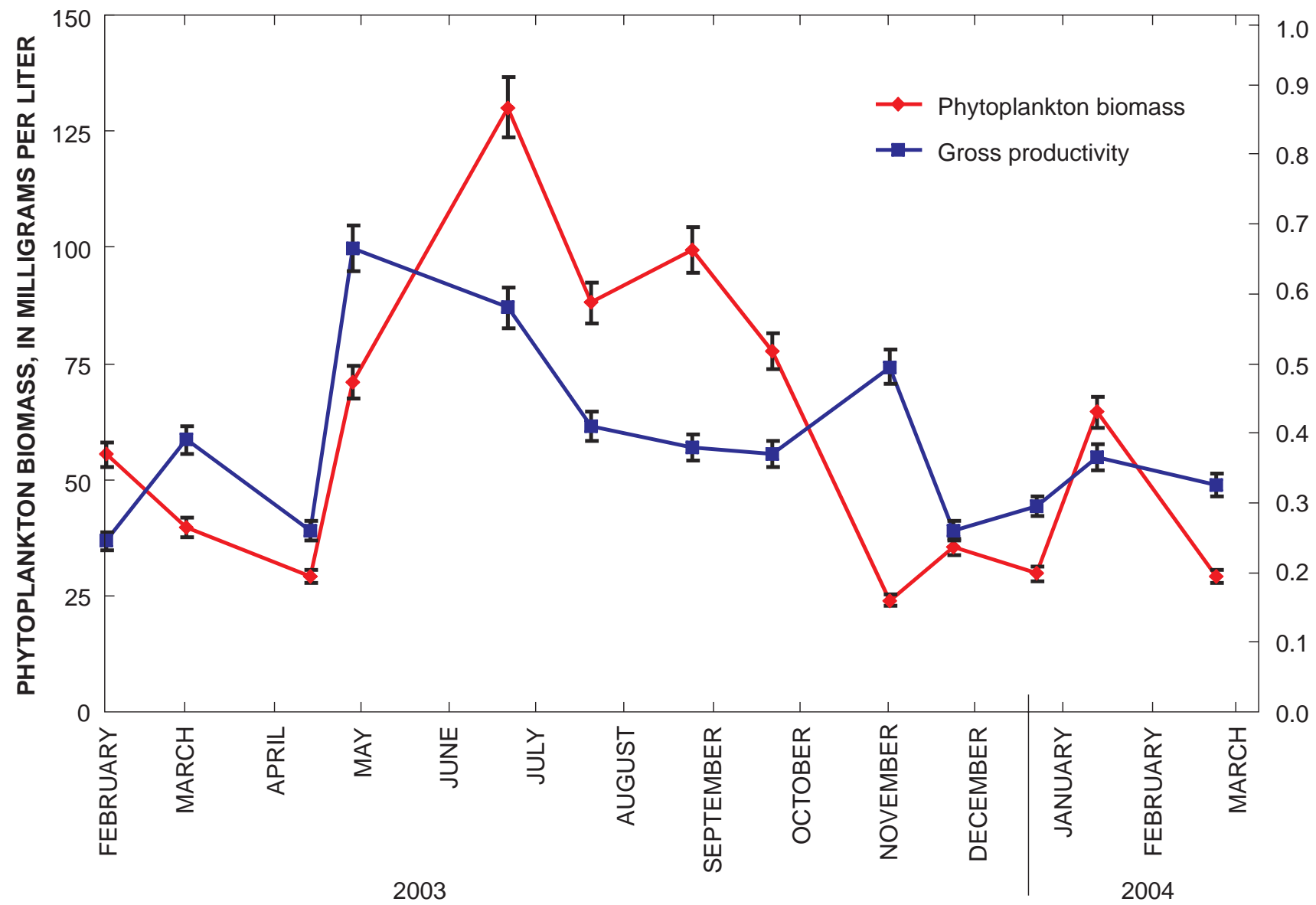

Figure 10. The relation between phytoplankton biomass and gross productivity rates at the Laguna de Las Salinas from February 2003 to March 2004. 


\section{Fecal Bacteria Concentration}

Fecal bacterial indicators, such as fecal coliforms and Escherichia coli (E. coli), are microorganisms that can be used to indicate the presence of human and other animal waste. Fecal indicators were sampled and analyzed on a roughly monthly basis in the Laguna de Las Salinas at stations 3, 4, 8 (fig. 7), and at a supplemental station established near sub-standard housing units without proper sanitary systems, located along the southeastern shoreline of the lagoon (fig. 7). Since coliform bacteria cannot live for prolonged periods outside a host, a positive test result indicates recent fecal contamination or inappropriate sewer processing.

Potential fecal contamination sources into the lagoon include: (1) river discharges that could bring polluted waters from the sea into the lagoon through the inlet channel during high tides; (2) overflows from main sewer lines that run parallel to highway PR-2 to the northern shoreline of the lagoon;

(3) overflow of a sewer main from the public beach west of the lagoon during storm runoff; (4) possible illegal raw sewage discharge from the sub-standard housing units that are located along the southeastern shoreline of the lagoon; and (5) from the Ponce Regional wastewater treatment plant ocean outfall.

Water samples were collected for fecal coliforms and E. coli using the "hand-dip" method, which is applicable to streams and standing waters (Clesceri and others, 1998). At each station, two or three sterilized borosilicate $100-\mathrm{mL}$ bottles were immersed in the water at a depth of about $15 \mathrm{~cm}$, leaving a small air pocket to maintain oxygenation and to allow subsequent mixing before analysis. The analytical procedure used to measure fecal coliform and $E$. coli bacteria concentrations consisted of the membrane microfiltration method, followed by incubation in specific culture medias, temperatures, and time periods. For fecal coliforms, bacteria are cultured in $\mathrm{m}-\mathrm{FC}$ agar and are incubated at $44.5^{\circ} \mathrm{C}$ for 20 to 24 hours, whereas $E$. coli bacteria are cultured in m-TEC agar and incubated at $35^{\circ} \mathrm{C}$ for 2 hours and then at $44.5^{\circ} \mathrm{C}$ for 20 to 24 hours (Clesceri and others, 1998). The results are reported as colonies of bacteria per $100 \mathrm{~mL}$ of sample.

The PREQB fecal coliform standard for SB waters establish that the geometric mean concentration of at least five samples obtained in sequential order should not exceed 200 colonies per $100 \mathrm{~mL}$ (col/100 mL), and not more than 20 percent of the samples should exceed $400 \mathrm{col} / 100 \mathrm{~mL}$ (Puerto Rico Environmental Quality Board, 2003). The regulations do not specify the time period during which the sequential samples must be obtained. There are no current standards for E. coli concentrations for ambient waters in Puerto Rico.

Fecal coliform concentrations exceeded the 200 $\mathrm{col} / 100 \mathrm{~mL}$, only once during the study (appendix 4); the lagoon can be considered to be in compliance with the PREQB standards. In general, fecal coliform and $E$. coli counts were less than $50 \mathrm{col} / 100 \mathrm{~mL}$; the higher bacterial counts occurred at station 8 and near the houses (appendix 4). The peak fecalindicator bacteria concentration followed coincidentally the rainfall peak of late April 2003 indicating that high runoff may have contributed fecal bacteria contamination. Other samples collected after high rainfall did not show high bacteria counts, indicating that the source of contamination may have been a point source, a defective sewer line along highway PR-2 reported to the PREQB by local residents. The sewer line was repaired and bacterial counts after May 7, 2003, did not exceed $200 \mathrm{col} / 100 \mathrm{~mL}$.

E. coli counts typically were higher than the fecal coliform colony counts (appendix 4). These results were unexpected, because $E$. coli bacteria are part of the larger fecal coliforms group. A possible explanation for this could be the ability of $E$. coli bacteria to adapt to harsh conditions. It is likely that when higher $E$. coli counts occurred, all of the fecal coliform colonies developed were actually $E$. coli bacteria, which did not grow as well in the fecal coliform culture media as in the more bacteria-specific and growth-enhancing culture media and temperature in which $E$. coli were incubated. The bacteriaspecific culture media and incubation temperature for the $E$. coli may have favored growth of $E$. coli over that of fecal coliform colonies.

\section{Summary and Conclusions}

The Laguna de Las Salinas is a valuable coastal resource subjected to a variety of factors that are affecting the health of the lagoon. Development has reduced the size of the drainage area by about 3 percent, and future construction projects threaten to alter the basin further by modifying runoff to the lagoon.

From January to December 2003, rainfall was higher than normal and three intense rainfall events occurred in April, November, and December 2003, with rainfall amounts of 360, 270, and 170 millimeters, respectively. These events exceeded the long-term monthly averages and represented about 70 percent of the total rainfall recorded in 2003. The intense rainfall caused an estimated twofold increase in the lagoon surface area, from 35 to about 70 hectares. Fresh water influx into the Laguna de Las Salinas was virtually limited to these intense rainfall events. Ground-water flow into the basin was estimated at 16 millimeters per year (about 2 percent of the mean annual rainfall).

The Laguna de Las Salinas water exchange with the sea is controlled by the narrow, shallow channel and tides along the Caribbean Sea coast. Extreme rainfall and winds in excess of 16 kilometers per hour, however, were found to interfere with the normal ebb and flood tide patterns of the lagoon.

A bathymetric survey showed that the Laguna de Las Salinas has a volume of approximately 217,000 cubic meters. At the time of this study, the maximum water depth was 90 centimeters and the mean water depth was about 60 centimeters.

The physical and chemical properties of water in the Laguna de Las Salinas were found to be in compliance with the PREQB standards with some isolated exceptions. The lagoon is a generally homogeneous water body, exhibiting temporal 
rather than spatial variations, with minimal vertical stratification. The temperature of the water ranged from about 24 to 26 degrees Celsius during winter months and between about 27 and 31 degrees Celsius during the summer months. Afternoon temperatures were about 1.5 degrees Celsius higher than morning temperatures. The $\mathrm{pH}$ of the water was between 7.5 and 8.6 standard units and did not exceed PREQB standards. Higher values ranging from 7.7 to 8.6 were recorded in the lagoon with lower values ranging from 7.7 to 7.9 standard units in the channel. Dissolved oxygen concentrations exhibited temporal rather than spatial variation, with practically no vertical stratification. The higher dissolved oxygen concentration variations occurred at stations located in the periphery of the lagoon, with less variations in the center of the lagoon. The Secchi disk water transparency was consistently low, with most readings generally less than 40 centimeters. Since the lagoon has no perennial streams, sediment resuspension and high organic material generation and resuspension are presumed to be the principal factors affecting water transparency and light penetration. Specific conductance and salinity measurements showed temporal rather than spatial variations, and were directly associated with rainfall and southern coastal tides. Low conductivities and low salinity were recorded during November 2003, with higher conductivities and hypersaline conditions recorded during February 2003.

Total nitrogen as $\mathrm{N}$ and total phosphorus as $\mathrm{P}$

concentrations were below the PREQB standards of 5.0 and 1.0 milligrams per liter, respectively. Total nitrogen concentrations ranged from 1.2 to 2.62 milligrams per liter, with a mean of about 1.9 milligrams per liter. Dissolved nitrogen concentration ranged from 0.62 to 1.42 milligrams per liter, with a mean of about 1.0 milligram per liter. Organic nitrogen constituted about 96 percent of the total nitrogen in the Laguna de Las Salinas with more than 50 percent of the organic nitrogen occurring in the dissolved form. Ammonia concentrations ranged from 0.03 to 0.08 milligram per liter, representing less than 3 percent of the total nitrogen portion. Nitrate and nitrite constituted about 1 percent of the total nitrogen. Total phosphorus concentrations in the Laguna de Las Salinas ranged from 0.02 to 0.06 milligram per liter. Orthophosphate constituted more than 75 percent of the total phosphorus in the Laguna de Las Salinas, with more than 60 percent present in the dissolved form. The average concentration of total organic carbon ranged from 12.0 to 19.0 milligrams per liter. Almost 80 percent of organic carbon was found in the dissolved form and concentrations ranged from 9.4 to 15.0 milligrams per liter. The average concentration of chlorophyll aranged from about 3.6 to 22.5 micrograms per liter. The highest concentrations occurred in November and December 2003 (a period of above normal rainfall) and the lowest concentration occurred in September 2003. Most chlorophyll $b$ concentrations were below the laboratory detection limit of 0.10 microgram per liter; the detection limit of 0.10 microgram per liter was exceeded twice-once on May 22 and once on October 15, 2003.

Light and dark bottle primary productivity measurements were made at about monthly intervals between February 2003 and March 2004. The results indicate that the phytoplankton net primary productivity rate was about 1.3 grams of oxygen per cubic meter per day; the plankton daily respiration rate was about 6.2 grams of oxygen per cubic meter; and the mean daily gross productivity was 7.52 grams of oxygen per cubic meter. Diel primary productivity studies were conducted in May 1 and October 16, 2003, and the net community productivity averaged 13.6 grams of oxygen per cubic meter per day. The mean community respiration rate was 59.2 grams of oxygen per cubic meter per day, and the mean community gross productivity was 72.8 grams of oxygen per cubic meter per day. Periphyton and macrophytes were predominant in primary productivity and produced 12.3 grams of oxygen per cubic meter per day (about 90 percent).

Samples for fecal bacterial indicators were obtained at about monthly intervals during the study at three locations. Fecal coliform bacteria counts exceeded the PREQB standard only once during the study.

The Laguna de Las Salinas is a unique ecosystem in the southern coast of Puerto Rico with potential ecological value. Although its primary productivity is substantially high, making the lagoon a vigorous food factory, most of the biomass standing crop is generated by benthic organisms, indicating that the food supply is stored inside the lagoon. For this food supply to become available for a larger range of free-living organisms, other organisms would have to enter the lagoon through the narrow and shallow channel that connects the lagoon to the Caribbean Sea. The small size of the channel, which hampers water exchange with the sea also restricts the flow of secondary producers in the food chain. A wider and/or deeper channel would enhance the connection between the lagoon and the sea and improve the ecological potential of the Laguna de Las Salinas. 


\section{References Cited}

Anderson, H.R., 1977, Ground water in the Lajas valley, Puerto Rico: U.S. Geological Survey Water-Resources Investigations 68-76, 46 p.

Benke, A.C., 1993, Concepts and patterns of invertebrate production in running waters: Verh. Internat. Verein. Limnol., v. 25, p. 15-38.

Clesceri, L.S., Greenberg, A.E., and Eaton, A.E., eds., 1998, Standard Methods for the examination of water and wastewater (20th ed.): 10 chap., 1,220 p.

Díaz, P.L., Aquino, Zaida, Figueroa-Alamo, Carlos, García, René, and Sánchez, A.V., 2004, Water resources data Puerto Rico and the U.S. Virgin Islands, Water Year 2002: U.S. Geological Survey Water-Data Report PR-02-1, p. 274-311

Environmental Systems Research Institute, Inc., 1992, Surface modeling with TIN, Surface analysis and display: Environmental Systems Research Institute, Inc., Redlands, California, p. 4-1, 6-1.

Fox, R., 2000, Phytoplankton primary productivity: Laboratory exercises for biology 306: accessed October 2004 at http://www.lander.edu/RSFOX/306prod-BLab.html.

Gómez-Gómez, Fernando, 1984, Water resources of the lower Río Grande de Manatí Valley, Puerto Rico: U.S. Geological Survey Water Resources Investigations Report 83-4199, $42 \mathrm{p}$.

Hutchinson, G.E., 1973, Eutrophication, The scientific background of a contemporary problem: American Scientist, v. 61, p. 269-279.

Krushensky, R.D., and Monroe, W.H., 1978, Geology map of the Peñuelas and Punta Cucharas quadrangles, Puerto Rico: U.S. Geological Survey Miscellaneous Investigations Series Map I-1042, 1 sheet, scale 1:20000.

Lecture Notes in Biological Oceanography, 1999, Introduction to biological oceanography, primary productivity: chap. 13-16, accessed October 2004 at http://www.duedall.fit.edu/ ocn1010eng/13apr.htm

National Oceanographic and Atmospheric Administration, 1970-1998, Southeast Regional Climate Center, Climate Information, Historical Climate Summaries for Puerto Rico and the U.S. Virgin Islands: accessed May 2004 at http:// cirrus.dnr.state.sc.us/cgi-bin/sercc/cliMAIN.pl?pr7295.

National Weather Service, 1997, Glossary of hydrologic related terms: accessed January 2005 at http://www.crh.noaa.gov/ hsd/hydefd-f.html\#e.
Odum, H.T., 1956, Primary production in flowing waters: Limnology and Oceanography, v. 1, no. 2, p. 102-117.

OHM Remediation Services Corp., 1992, Hydrogeologic data interpretation of Protección Técnica Ecológica Inc. site at Peñuelas, Puerto Rico: Technical Report 10635, 32 p.

Puerto Rico Environmental Quality Board, 2003, Junta de Calidad Ambiental de Puerto Rico, Reglamentos de Estándares de Calidad de Agua de Puerto Rico: Versión Enmendada marzo 2003, 82 p.

Quiñones-Márquez, Ferdinand, and Guzmán-Ríos, Sénen, 1985, Determinación de caudal y técnicas de muestreo en agua superficial: U.S. Geological Survey Water-Resources Investigations Report 85-89, 67 p.

Redfield, A.C., Ketchum, B.H., and Richards, F.A., 1963, The influence of organisms on the composition of sea- water, in The sea, M.N. Hill, ed.: Wiley \& Sons, New York, v. 2, p. 26-77.

Riley, J.P., and Chester, R., 1971, Introduction to marine chemistry: New York, Academic Press, 465 p.

Rodríguez-Martínez, Jesús, 1996, Hydrogeology and groundwater/surface-water relations in the Bajura area of the municipio of Cabo Rojo, southwestern Puerto Rico: U.S. Geological Survey Water-Resources Investigations Report 95-4159, 31 p.

Santiago-Rivera, Luis, and Quiñones-Aponte, Vicente, 1995, Hydrology of Laguna Joyuda, Puerto Rico: U.S. Geological Survey Water-Resources Investigations Report 93-4135, $26 \mathrm{p}$.

U.S. Geological Survey, 1997, Ground-water atlas of the United States: Segment 13, Alaska, Hawaii, Puerto Rico, and the U.S. Virgin Islands: U.S. Geological Survey Hydrologic Investigations Atlas 730-N, p. N22-26.

Vollenweinder, R.V., 1968, The scientific basis of lake and stream eutrophication, with particular reference to phosphorus and nitrogen as eutrophication factors: Technical Report DAS/CSI/68, Organization of Economic Cooperation and Development, Paris, 27: 1-182.

Webb, R.M.T., and Gómez-Gómez, Fernando, 1997, Synoptic survey of water quality and bottom sediments, San Juan Bay Estuary System, Puerto Rico, December 1994-July 1995: U.S. Geological Survey Water-Resources Investigations Report 97-4144, 69 p.

Wetzel, R.G., 2001, Limnology: Lake and River Ecosystems (3rd ed.): chap. 8, p. 129-150. 


\section{Appendixes 1-4}


Appendix 1. On-site determination of $\mathrm{pH}$, temperature, specific conductance, dissolved oxygen, salinity, and secchi disk depth for water-quality sites sampled from February 2003 to March 2004 at the Laguna de Las Salinas, Ponce, Puerto Rico. Top values were obtained at about 15 centimeters deep and bottom values were obtained about 10 centimeters from the lagoon's bottom. Discharge data is presented for station 3 only.

[T, temperature in degrees Celsius; SC, specific conductance in microsiemens per centimeter; DO, dissolved oxygen; SAL, salinity in parts per thousand; SD, Secchi disk depth in centimeters; Q, discharge in cubic meters per second; E, ebb flow; F, flood flow; ---, not collected]

\begin{tabular}{|c|c|c|c|c|c|c|}
\hline Station 1 (50119300) & $\mathrm{pH}$ & $\mathrm{T}$ & SC & DO & SAL & SD \\
\hline \multicolumn{7}{|c|}{ January 24, 2003 - 9:49 a.m. } \\
\hline Top & 8.2 & 26.8 & 72,300 & 4.5 & 49.7 & \\
\hline Bottom & --- & --- & --- & --- & --- & 53 \\
\hline \multicolumn{7}{|c|}{ February 25, 2003 - 9:35 a.m. } \\
\hline Top & 8.2 & 25.8 & 76,900 & 4.8 & 53.4 & \\
\hline Bottom & --- & --- & --- & --- & --- & 48 \\
\hline \multicolumn{7}{|c|}{ March 25, 2003 - 9:24 a.m. } \\
\hline Top & 8.0 & 28.7 & 70,300 & 4.3 & 47.8 & \\
\hline Bottom & 8.0 & 28.4 & 70,500 & 2.9 & 46.9 & 48 \\
\hline \multicolumn{7}{|c|}{ May 7, 2003 - 8:15 a.m. } \\
\hline Top & 8.6 & 27.3 & 41,500 & 5.2 & 26.5 & \\
\hline Bottom & 8.5 & 27.3 & 41,500 & 5.1 & 26.5 & 33 \\
\hline \multicolumn{7}{|c|}{ May 22, 2003 - 8:15 a.m. } \\
\hline Top & 8.0 & 29.4 & 49,300 & 5.2 & 32.1 & \\
\hline Bottom & 8.0 & 29.4 & 49,300 & 3.8 & 32.1 & 33 \\
\hline \multicolumn{7}{|c|}{ July 15, 2003 - 8:45 a.m. } \\
\hline Top & 7.5 & 28.1 & 63,300 & 5.6 & 42.7 & \\
\hline Bottom & 7.5 & 28.0 & 63,300 & 5.1 & 42.7 & 25 \\
\hline \multicolumn{7}{|c|}{ August 13, 2003 - 9:00 a.m. } \\
\hline Top & 8.2 & 29.1 & 72,200 & 4.5 & 49.6 & \\
\hline Bottom & 8.2 & 29.1 & 72,300 & 4.0 & 49.6 & 25 \\
\hline \multicolumn{7}{|c|}{ September 17, 2003 - 8:45 a.m. } \\
\hline Top & 7.8 & 30.4 & 70,300 & 4.7 & 48.3 & \\
\hline Bottom & 7.8 & 30.5 & 70,800 & 4.6 & 48.3 & 46 \\
\hline \multicolumn{7}{|c|}{ October 15, 2003 - 8:51 a.m. } \\
\hline Top & 8.4 & 30.1 & 57,700 & 4.8 & 38.3 & \\
\hline Bottom & 8.4 & 30.1 & 57,800 & 4.5 & 38.4 & 61 \\
\hline \multicolumn{7}{|c|}{ November 25, 2003 - 9:15 a.m. } \\
\hline Top & 7.7 & 27.2 & 21,100 & 2.8 & 12.6 & \\
\hline Bottom & 7.7 & 27.9 & 21,900 & 2.1 & 13.0 & 61 \\
\hline \multicolumn{7}{|c|}{ December 17, 2003 - 8:48 a.m. } \\
\hline Top & 8.3 & 25.5 & 21,400 & 6.9 & 12.8 & \\
\hline Bottom & 8.2 & 25.5 & 21,400 & 6.8 & 12.8 & 36 \\
\hline \multicolumn{7}{|c|}{ January 15, 2004 - 8:57 a.m. } \\
\hline Top & 8.4 & 25.9 & 34,000 & 6.1 & 21.3 & \\
\hline Bottom & 8.4 & 25.9 & 34,000 & 6.0 & 21.3 & 46 \\
\hline \multicolumn{7}{|c|}{ February 5, 2004 - 8:35 a.m. } \\
\hline Top & 8.1 & 24.2 & 41,000 & 4.7 & 26.2 & \\
\hline Bottom & 8.1 & 24.2 & 41,000 & 4.3 & 26.2 & 25 \\
\hline \multicolumn{7}{|c|}{ March 18, 2003 - 9:00 a.m. } \\
\hline Top & 7.9 & 26.1 & 54,800 & 6.1 & 36.3 & \\
\hline Bottom & 7.9 & 26.2 & 54,800 & 5.8 & 36.3 & 41 \\
\hline
\end{tabular}


Appendix 1. On-site determination of $\mathrm{pH}$, temperature, specific conductance, dissolved oxygen, salinity, and secchi disk depth for water-quality sites sampled from February 2003 to March 2004 at the Laguna de Las Salinas, Ponce, Puerto Rico. Top values were obtained at about 15 centimeters deep and bottom values were obtained about 10 centimeters from the lagoon's bottom. Discharge data is presented for station 3 only.-Continued

[T, temperature in degrees Celsius; SC, specific conductance in microsiemens per centimeter; DO, dissolved oxygen; SAL, salinity in parts per thousand; SD, Secchi disk depth in centimeters; Q, discharge in cubic meters per second; E, ebb flow; F, flood flow; ---, not collected]

\begin{tabular}{|c|c|c|c|c|c|c|}
\hline Station 2 (50119310) & $\mathrm{pH}$ & $\mathrm{T}$ & SC & DO & SAL & SL \\
\hline \multicolumn{7}{|c|}{ January 24, 2003 - 9:45 a.m. } \\
\hline Тор (0945) & 8.3 & 26.5 & 71,900 & 5.9 & 49.4 & \\
\hline Bottom & 8.2 & 28.2 & 72,200 & 7.0 & 49.6 & 84 \\
\hline \multicolumn{7}{|c|}{ February 25, 2003 - 9:20 a.m. } \\
\hline Top & 8.2 & 25.5 & 76,300 & 5.6 & 52.9 & \\
\hline Bottom & 8.2 & 25.6 & 76,300 & 5.7 & 52.9 & 36 \\
\hline \multicolumn{7}{|c|}{ March 25, 2003 - 8:45 a.m. } \\
\hline Top & 8.1 & 28.5 & 70,200 & 5.8 & 48.9 & \\
\hline Bottom & 8.0 & 28.5 & 70,200 & 4.8 & 47.8 & 66 \\
\hline \multicolumn{7}{|c|}{ May 7, 2003 - 8:10 a.m. } \\
\hline Top & 8.6 & 27.3 & 41,500 & 7.2 & 26.5 & \\
\hline Bottom & 8.5 & 27.4 & 41,600 & 6.3 & 26.6 & 41 \\
\hline \multicolumn{7}{|c|}{ May 22, 2003 - 8:00 a.m. } \\
\hline Top & 8.2 & 29.8 & 49,500 & 7.6 & 32.3 & \\
\hline Bottom & 8.3 & 29.8 & 49,600 & 7.3 & 32.3 & 33 \\
\hline \multicolumn{7}{|c|}{ July 15, 2003 - 8:20 a.m. } \\
\hline Тор & 7.6 & 28.1 & 63,100 & 6.1 & 42.5 & \\
\hline Bottom & 7.6 & 28.1 & 63,100 & 6.0 & 42.5 & 28 \\
\hline \multicolumn{7}{|c|}{ August 13, 2003 - 8:50 a.m. } \\
\hline Тор & 8.2 & 29.5 & 72,200 & 5.5 & 49.6 & \\
\hline Bottom & 8.2 & 29.5 & 72,200 & 5.3 & 49.5 & 28 \\
\hline \multicolumn{7}{|c|}{ September 17, 2003 - 8:30 a.m. } \\
\hline Top & 8.0 & 30.5 & 70,300 & 6.1 & 47.9 & \\
\hline Bottom & 8.0 & 30.5 & 70,200 & 5.8 & 47.9 & 46 \\
\hline \multicolumn{7}{|c|}{ October 15, 2003 - 8:30 a.m. } \\
\hline Top & 8.6 & 30.3 & 57,200 & 7.3 & 37.9 & \\
\hline Bottom & 8.5 & 31.4 & 59,200 & 6.8 & 39.4 & 46 \\
\hline \multicolumn{7}{|c|}{ November 25, 2003 - 8:50 a.m. } \\
\hline Top & 7.9 & 27.0 & 20,900 & 6.9 & 12.5 & \\
\hline Bottom & 7.6 & 30.3 & 31,300 & 1.3 & 19.5 & 51 \\
\hline \multicolumn{7}{|c|}{ December 17, 2003 - 8:25 a.m. } \\
\hline Top & 8.2 & 25.6 & 21,300 & 7.2 & 12.8 & \\
\hline Bottom & 8.2 & 25.6 & 21,300 & 6.6 & 12.8 & 36 \\
\hline \multicolumn{7}{|c|}{ January 15, 2004 - 8:33 a.m. } \\
\hline Top & 8.5 & 26.1 & 34,200 & 7.3 & 21.4 & \\
\hline Bottom & 8.5 & 26.1 & 34,200 & 7.2 & 21.5 & 46 \\
\hline \multicolumn{7}{|c|}{ February 5, 2004 - 8:05 a.m. } \\
\hline Top & 8.2 & 24.8 & 41,400 & 5.8 & 26.5 & \\
\hline Bottom & 8.2 & 24.8 & 41,400 & 5.5 & 26.5 & 25 \\
\hline \multicolumn{7}{|c|}{ March 18, 2004 - 8:40 a.m. } \\
\hline Top & 8.0 & 26.3 & 54,900 & 6.5 & 36.3 & \\
\hline Bottom & 8.0 & 26.3 & 54,900 & 6.3 & 36.3 & 38 \\
\hline
\end{tabular}


Appendix 1. On-site determination of $\mathrm{pH}$, temperature, specific conductance, dissolved oxygen, salinity, and secchi disk depth for water-quality sites sampled from February 2003 to March 2004 at the Laguna de Las Salinas, Ponce, Puerto Rico. Top values were obtained at about 15 centimeters deep and bottom values were obtained about 10 centimeters from the lagoon's bottom. Discharge data is presented for station 3 only.-Continued

[T, temperature in degrees Celsius; SC, specific conductance in microsiemens per centimeter; DO, dissolved oxygen; SAL, salinity in parts per thousand; SD, Secchi disk depth in centimeters; Q, discharge in cubic meters per second; E, ebb flow; F, flood flow; ---, not collected]

\begin{tabular}{|c|c|c|c|c|c|c|c|}
\hline Station 3 (50119320) & $\mathrm{pH}$ & $\mathrm{T}$ & SC & DO & SAL & SD & $0(E / F)$ \\
\hline \multicolumn{8}{|l|}{ January 24, 2003} \\
\hline Morning - 8:15 a.m. & 7.5 & 26.3 & 55,200 & 5.7 & 36.6 & & \\
\hline Afternoon - p.m. & 8.3 & 30.9 & 68,100 & 7.8 & 47.0 & --- & \\
\hline \multicolumn{8}{|l|}{ February 25, 2003} \\
\hline Morning - 7:20 a.m. & 7.6 & 26.0 & 56,600 & 5.8 & 37.5 & & $0.14(\mathrm{~F})$ \\
\hline Afternoon - 2:00 p.m. & 7.9 & 30.0 & 76,300 & 9.2 & 52.5 & --- & $0.06(\mathrm{E})$ \\
\hline \multicolumn{8}{|l|}{ March 25, 2003} \\
\hline Morning - 7:30 a.m. & 7.3 & 27.5 & 53,200 & 4.7 & 34.0 & & $0.09(\mathrm{~F})$ \\
\hline Afternoon - 2:30 p.m. & 7.9 & 32.7 & 67,000 & 6.4 & 45.7 & --- & $0.14(\mathrm{E})$ \\
\hline \multicolumn{8}{|l|}{ May 7, 2003} \\
\hline Morning - 6:45 a.m. & 7.5 & 27.8 & 54,900 & 4.7 & 36.3 & & $0.07(\mathrm{~F})$ \\
\hline Afternoon - 4:40 p.m. & 8.4 & 31.5 & 41,900 & 9.9 & 26.7 & --- & $0.13(\mathrm{E})$ \\
\hline \multicolumn{8}{|l|}{ May 22, 2003} \\
\hline Morning - 6:50 a.m. & 7.1 & 28.6 & 55,400 & 4.3 & 36.6 & & $0.12(\mathrm{~F})$ \\
\hline Afternoon - 2:10 p.m. & 8.0 & 34.2 & 50,600 & 10.7 & 32.9 & --- & $0.10(\mathrm{E})$ \\
\hline \multicolumn{8}{|l|}{ July 15, 2003} \\
\hline Morning - 7:10 a.m. & 8.1 & 26.5 & 56,900 & 4.7 & 38.0 & & $0.11(\mathrm{E})$ \\
\hline Afternoon - 1:45 p.m. & 7.5 & 30.6 & 64,300 & 8.2 & 43.3 & --- & $0.19(\mathrm{~F})$ \\
\hline \multicolumn{8}{|l|}{ August 13, 2003} \\
\hline Morning - 6:50 a.m. & 7.7 & 28.2 & 69,200 & 2.9 & 47.0 & & $0.07(\mathrm{E})$ \\
\hline Afternoon - 3:35 p.m. & 8.0 & 32.0 & 55,300 & 6.8 & 36.4 & --- & 0 \\
\hline \multicolumn{8}{|l|}{ September 17, 2003} \\
\hline Morning - 7:10 a.m. & 7.8 & 29.5 & 70,600 & 2.8 & 48.3 & & $0.10(\mathrm{E})$ \\
\hline Afternoon -1:50 p.m. & 8.04 & 31.84 & 54,913 & 7.46 & 36.16 & --- & $0.11(\mathrm{~F})$ \\
\hline \multicolumn{8}{|l|}{ October 15, 2003} \\
\hline Morning - 7:15 a.m. & 8.2 & 29.5 & 57,300 & 4.6 & 38.1 & & $0.22(\mathrm{E})$ \\
\hline Afternoon - 2:15 p.m. & 7.9 & 32.1 & 54,200 & 6.7 & 35.7 & --- & $0.10(F)$ \\
\hline \multicolumn{8}{|l|}{ November 25, 2003} \\
\hline Morning - 7:15 a.m. & 7.6 & 26.5 & 20,900 & 4.9 & 12.5 & & $0.19(\mathrm{E})$ \\
\hline Afternoon - 2:00 p.m. & 7.6 & 29.8 & 21,600 & 8.0 & 12.9 & --- & 0 \\
\hline \multicolumn{8}{|l|}{ December 17, 2003} \\
\hline Morning - 7:15 a.m. & 8.2 & 24.9 & 21,400 & 5.3 & 12.8 & & $0.13(E)$ \\
\hline Afternoon - 1:00 p.m. & 8.2 & 29.7 & 21,600 & 9.4 & 12.9 & & 0 \\
\hline \multicolumn{8}{|l|}{ January 15, 2004} \\
\hline Morning - 7:20 a.m. & 7.5 & 26.0 & 55,500 & 5.0 & 35.3 & & $0.06(\mathrm{~F})$ \\
\hline Afternoon - 2:00 p.m. & 8.0 & 29.7 & 36,700 & 9.1 & 23.1 & --- & $0.04(\mathrm{E})$ \\
\hline \multicolumn{8}{|l|}{ February 5, 2004} \\
\hline Morning - 7:00 a.m. & 7.5 & 25.5 & 54,900 & 5.1 & 36.3 & & $0.08(\mathrm{~F})$ \\
\hline Afternoon - 2:15 p.m. & 7.7 & 28.5 & 55,300 & 8.5 & 36.6 & --- & $0.09(\mathrm{~F})$ \\
\hline \multicolumn{8}{|l|}{ March 18, 2004} \\
\hline Morning - 7:20 a.m. & 7.5 & 26.3 & 56,100 & 5.7 & 37.3 & --- & $0.12(\mathrm{E})$ \\
\hline Afternoon - 1:45 p.m. & 7.7 & 26.9 & 56,100 & 7.3 & 37.2 & & $0.10(\mathrm{E})$ \\
\hline
\end{tabular}


Appendix 1. On-site determination of $\mathrm{pH}$, temperature, specific conductance, dissolved oxygen, salinity, and secchi disk depth for water-quality sites sampled from February 2003 to March 2004 at the Laguna de Las Salinas, Ponce, Puerto Rico. Top values were obtained at about 15 centimeters deep and bottom values were obtained about 10 centimeters from the lagoon's bottom. Discharge data is presented for station 3 only.-Continued

[T, temperature in degrees Celsius; SC, specific conductance in microsiemens per centimeter; DO, dissolved oxygen; SAL, salinity in parts per thousand; SD, Secchi disk depth in centimeters; Q, discharge in cubic meters per second; E, ebb flow; F, flood flow; ---, not collected]

\begin{tabular}{|c|c|c|c|c|c|c|}
\hline Station 4 (50119330) & $\mathrm{pH}$ & $\mathrm{T}$ & SC & DO & SAL & SD \\
\hline \multicolumn{7}{|l|}{ January 24, 2003} \\
\hline Top & --- & --- & --- & --- & --- & --- \\
\hline Bottom & --- & --- & --- & --- & --- & --- \\
\hline \multicolumn{7}{|c|}{ February 25, 2003 - 10:10 a.m. } \\
\hline Тор & 8.3 & 25.9 & 76,400 & 7.4 & 53.0 & \\
\hline Bottom & 8.2 & 25.9 & 76,300 & 7.1 & 52.9 & 56 \\
\hline \multicolumn{7}{|c|}{ March 25, 2003 - 9:00 a.m. } \\
\hline Тор & 8.1 & 28.3 & 71,000 & 5.4 & 47.4 & \\
\hline Bottom & 8.1 & 28.3 & 71,400 & 3.0 & 47.2 & 53 \\
\hline \multicolumn{7}{|c|}{ May 7, 2003 - 8:40 a.m. } \\
\hline Тор & 8.6 & 27.4 & 41,500 & 6.4 & 26.6 & \\
\hline Bottom & 8.6 & 27.5 & 41,700 & 6.2 & 26.7 & 33 \\
\hline \multicolumn{7}{|c|}{ May 22, 2003 - 8:40 a.m. } \\
\hline Тор & 8.2 & 29.8 & 49,500 & 7.3 & 32.3 & \\
\hline Bottom & 8.3 & 29.8 & 49,500 & 7.0 & 32.3 & 36 \\
\hline \multicolumn{7}{|c|}{ July 15, 2003 - 8:35 a.m. } \\
\hline Top & 7.6 & 28.2 & 63,100 & 6.6 & 42.5 & \\
\hline Bottom & 7.5 & 28.2 & 63,100 & 6.6 & 42.5 & 25 \\
\hline \multicolumn{7}{|c|}{ August 13, 2003 - 8:45 a.m. } \\
\hline Top & 8.2 & 29.3 & 71,700 & 6.8 & 49.1 & \\
\hline Bottom & 8.1 & 29.3 & 70,500 & 2.6 & 49.9 & 30 \\
\hline \multicolumn{7}{|c|}{ September 17, 2003 - 8:40 a.m. } \\
\hline Top & 8.0 & 30.4 & 70,400 & 6.8 & 48.1 & \\
\hline Bottom & 8.0 & 30.4 & 70,400 & 6.6 & 48.0 & 46 \\
\hline \multicolumn{7}{|c|}{ October 15, 2003 - 8:35 a.m. } \\
\hline Top & 8.6 & 30.2 & 57,200 & 7.6 & 37.9 & \\
\hline Bottom & 8.5 & 30.3 & 57,200 & 7.4 & 38.0 & 46 \\
\hline \multicolumn{7}{|c|}{ November 25, 2003 - 9:00 a.m. } \\
\hline Top & 8.0 & 27.1 & 21,000 & 7.2 & 12.5 & \\
\hline Bottom & 7.6 & 29.3 & 30,800 & 1.6 & 18.8 & 51 \\
\hline \multicolumn{7}{|c|}{ December 17, 2003 - 8:35 a.m. } \\
\hline Top & 8.3 & 25.7 & 21,400 & 7.6 & 12.8 & \\
\hline Bottom & 8.3 & 25.7 & 21,400 & 7.5 & 12.8 & 36 \\
\hline \multicolumn{7}{|c|}{ January 15, 2004 - 8:50 a.m. } \\
\hline Top & 8.4 & 26.2 & 34,200 & 7.2 & 21.4 & \\
\hline Bottom & 8.4 & 26.2 & 34,200 & 7.0 & 21.4 & 46 \\
\hline \multicolumn{7}{|c|}{ February 25, 2004 - 8:25 a.m. } \\
\hline Тор & 8.2 & 24.8 & 41,400 & 5.9 & 26.5 & \\
\hline Bottom & 8.2 & 24.8 & 41,400 & 5.6 & 26.5 & 25 \\
\hline \multicolumn{6}{|c|}{ March 18, 2004 - 8:55 a.m. } & \\
\hline Surface & 7.9 & 26.4 & 54,900 & 6.7 & 36.3 & \\
\hline Bottom & 7.9 & 26.4 & 54,900 & 6.4 & 36.3 & 41 \\
\hline
\end{tabular}


Appendix 1. On-site determination of $\mathrm{pH}$, temperature, specific conductance, dissolved oxygen, salinity, and secchi disk depth for water-quality sites sampled from February 2003 to March 2004 at the Laguna de Las Salinas, Ponce, Puerto Rico. Top values were obtained at about 15 centimeters deep and bottom values were obtained about 10 centimeters from the lagoon's bottom. Discharge data is presented for station 3 only.-Continued

[T, temperature in degrees Celsius; SC, specific conductance in microsiemens per centimeter; DO, dissolved oxygen; SAL, salinity in parts per thousand; SD, Secchi disk depth in centimeters; Q, discharge in cubic meters per second; E, ebb flow; F, flood flow; ---, not collected]

\begin{tabular}{|c|c|c|c|c|c|c|}
\hline Station 5 (50119340) & $\mathrm{pH}$ & $\mathrm{T}$ & SC & DO & SAL & SD \\
\hline \multicolumn{7}{|c|}{ January 24, 2004 - 9:55 a.m. } \\
\hline Тор & 8.3 & 27.3 & 72,000 & 5.9 & 49.6 & \\
\hline Bottom & --- & --- & --- & --- & --- & 48 \\
\hline \multicolumn{7}{|c|}{ February 25, 2003 - 9:55 a.m. } \\
\hline Тор & 8.2 & 25.8 & 75,600 & 5.8 & 52.3 & \\
\hline Bottom & 8.2 & 25.8 & 75,600 & 5.9 & 52.4 & 51 \\
\hline \multicolumn{7}{|c|}{ March 25, 2003 - 9:30 a.m. } \\
\hline Тop & 8.1 & 28.6 & 68,600 & 4.4 & 46.9 & \\
\hline Bottom & 8.0 & 28.8 & 68,700 & 3.9 & 46.5 & 51 \\
\hline \multicolumn{7}{|c|}{ May 7, 2003 - 8:55 a.m. } \\
\hline Top & 8.6 & 27.6 & 41,200 & 6.4 & 26.4 & \\
\hline Bottom & 8.7 & 27.6 & 41,200 & 6.3 & 26.3 & 38 \\
\hline \multicolumn{7}{|c|}{ May 22, 2003 - 8:25 a.m. } \\
\hline Top & 8.2 & 30.0 & 49,400 & 7.5 & 32.2 & \\
\hline Bottom & 8.2 & 30.1 & 49,400 & 7.4 & 32.2 & 41 \\
\hline \multicolumn{7}{|c|}{ July 15, 2003 - 8:50 a.m. } \\
\hline Тор & 7.5 & 28.0 & 62,600 & 6.6 & 42.1 & \\
\hline Bottom & 7.4 & 28.1 & 62,600 & 1.1 & 42.0 & 25 \\
\hline \multicolumn{7}{|c|}{ August 13, 2003 - 9:05 a.m. } \\
\hline Top & 8.2 & 29.7 & 71,500 & 6.7 & 48.9 & \\
\hline Bottom & 8.2 & 29.8 & 71,200 & 7.0 & 48.8 & 25 \\
\hline \multicolumn{7}{|c|}{ September 17, 2003 - 8:50 a.m. } \\
\hline Top & 8.1 & 30.4 & 70,000 & 6.7 & 47.5 & \\
\hline Bottom & 8.0 & 30.5 & 70,000 & 6.6 & 47.8 & 46 \\
\hline \multicolumn{7}{|c|}{ October 15, 2003 - 8:58 a.m. } \\
\hline Top & 8.4 & 29.9 & 56,800 & 6.6 & 37.6 & \\
\hline Bottom & 8.4 & 30.0 & 56,800 & 5.5 & 37.8 & 46 \\
\hline \multicolumn{7}{|c|}{ November 25, 2003 - 9:20 a.m. } \\
\hline Top & 7.9 & 27.2 & 20,900 & 6.8 & 12.5 & \\
\hline Bottom & 7.8 & 27.3 & 21,100 & 5.8 & 12.6 & 46 \\
\hline \multicolumn{7}{|c|}{ December 17, 2003 - 8:55 a.m. } \\
\hline Top & 8.3 & 25.9 & 21,300 & 7.5 & 12.8 & \\
\hline Bottom & 8.3 & 25.9 & 21,300 & 7.4 & 12.8 & 41 \\
\hline \multicolumn{7}{|c|}{ January 15, 2004 - 9:08 a.m. } \\
\hline Top & 8.4 & 26.8 & 33,900 & 6.1 & 21.2 & \\
\hline Bottom & 8.4 & 26.8 & 34,000 & 6.3 & 21.3 & 46 \\
\hline \multicolumn{7}{|c|}{ February 5, 2004 - 8:45 a.m. } \\
\hline Top & 8.2 & 24.6 & 41,200 & 5.8 & 26.4 & \\
\hline Bottom & 8.2 & 24.5 & 41,200 & 5.7 & 26.4 & 25 \\
\hline \multicolumn{7}{|c|}{ March 18, 2004 - 9:10 a.m. } \\
\hline Тор & 7.9 & 26.8 & 55,000 & 6.5 & 36.4 & \\
\hline Bottom & 7.9 & 26.9 & 55,000 & 6.3 & 36.4 & 41 \\
\hline
\end{tabular}


Appendix 1. On-site determination of $\mathrm{pH}$, temperature, specific conductance, dissolved oxygen, salinity, and secchi disk depth for water-quality sites sampled from February 2003 to March 2004 at the Laguna de Las Salinas, Ponce, Puerto Rico. Top values were obtained at about 15 centimeters deep and bottom values were obtained about 10 centimeters from the lagoon's bottom. Discharge data is presented for station 3 only.-Continued

[T, temperature in degrees Celsius; SC, specific conductance in microsiemens per centimeter; DO, dissolved oxygen; SAL, salinity in parts per thousand; SD, Secchi disk depth in centimeters; Q, discharge in cubic meters per second; E, ebb flow; F, flood flow; ---, not collected]

\begin{tabular}{|c|c|c|c|c|c|c|}
\hline Station 6 (50119350) & $\mathrm{pH}$ & $\mathrm{T}$ & SC & DO & SAL & SD \\
\hline \multicolumn{7}{|c|}{ January 24, 2003 - 10:25 a.m. } \\
\hline Тор & 8.3 & 26.8 & 72,400 & 5.0 & 49.8 & \\
\hline Bottom & --- & --- & --- & --- & --- & 71 \\
\hline \multicolumn{7}{|c|}{ February 25, 2003 - 10:45 a.m. } \\
\hline Top & 8.2 & 26.2 & 74,400 & 6.7 & 51.4 & \\
\hline Bottom & --- & --- & --- & --- & --- & 51 \\
\hline \multicolumn{7}{|c|}{ March 25, 2003 - 9:45 a.m. } \\
\hline Top & 8.0 & 28.7 & 70,000 & 3.8 & 47.3 & \\
\hline Bottom & 8.0 & 28.6 & 70,500 & 2.2 & 47.3 & 64 \\
\hline \multicolumn{7}{|c|}{ May 7, 2003 - 9:20 a.m. } \\
\hline Тор & 8.3 & 27.6 & 41,800 & 6.2 & 26.7 & \\
\hline Bottom & 8.4 & 27.8 & 41,700 & 5.6 & 26.6 & 41 \\
\hline \multicolumn{7}{|c|}{ May 22, 2003 - 8:55 a.m. } \\
\hline Тор & 8.3 & 29.8 & 49,500 & 6.5 & 32.2 & \\
\hline Bottom & 8.3 & 29.8 & 49,500 & 6.2 & 32.3 & 38 \\
\hline \multicolumn{7}{|c|}{ July 15, 2003 - 9:05 a.m. } \\
\hline Top & 7.6 & 27.8 & 63,100 & 7.2 & 42.5 & \\
\hline Bottom & 7.6 & 27.8 & 61,100 & 6.9 & 42.5 & 25 \\
\hline \multicolumn{7}{|c|}{ August 13, 2003 - 9:15 a.m. } \\
\hline Тор & 8.3 & 28.9 & 70,500 & 6.1 & 48.2 & \\
\hline Bottom & 8.3 & 28.9 & 71,800 & 6.1 & 49.3 & 30 \\
\hline \multicolumn{7}{|c|}{ September 17, 2003 - 8:55 a.m. } \\
\hline Top & 7.91 & 30.30 & 70,689 & 6.28 & 48.29 & \\
\hline Bottom & 7.92 & 30.30 & 70,689 & 6.08 & 48.29 & 46 \\
\hline \multicolumn{7}{|c|}{ October 15, 2003 - 9:11 a.m. } \\
\hline Тор & 8.4 & 30.5 & 57,200 & 7.4 & 37.9 & \\
\hline Bottom & 8.4 & 30.5 & 57,200 & 7.2 & 37.9 & 43 \\
\hline \multicolumn{7}{|c|}{ November 25, 2003 - 9:32 a.m. } \\
\hline Top & 7.8 & 27.4 & 21,100 & 6.5 & 12.6 & \\
\hline Bottom & 7.8 & 27.4 & 21,200 & 5.9 & 12.7 & 51 \\
\hline \multicolumn{7}{|c|}{ December 17, 2003 - 9:04 a.m. } \\
\hline Top & 8.3 & 25.5 & 21,400 & 7.5 & 12.8 & \\
\hline Bottom & 8.3 & 25.5 & 21,400 & 7.4 & 12.8 & 33 \\
\hline \multicolumn{7}{|c|}{ January 15, 2004 - 9:28 a.m. } \\
\hline Top & 8.4 & 25.9 & 33,000 & 6.8 & 21.3 & \\
\hline Bottom & 8.3 & 26.0 & 34,100 & 6.6 & 21.4 & 46 \\
\hline \multicolumn{7}{|c|}{ February 5, 2004 - 9:00 a.m. } \\
\hline Top & 8.1 & 24.0 & 41,100 & 5.8 & 26.3 & \\
\hline Bottom & 8.2 & 24.0 & 41,100 & 5.6 & 26.3 & 25 \\
\hline \multicolumn{7}{|c|}{ March 18, 2004 - 9:25 a.m. } \\
\hline Top & 7.9 & 26.0 & 55,000 & 7.1 & 36.4 & \\
\hline Bottom & 7.9 & 26.0 & 55,200 & 6.9 & 36.4 & 41 \\
\hline
\end{tabular}


Appendix 1. On-site determination of $\mathrm{pH}$, temperature, specific conductance, dissolved oxygen, salinity, and secchi disk depth for water-quality sites sampled from February 2003 to March 2004 at the Laguna de Las Salinas, Ponce, Puerto Rico. Top values were obtained at about 15 centimeters deep and bottom values were obtained about 10 centimeters from the lagoon's bottom. Discharge data is presented for station 3 only.-Continued

[T, temperature in degrees Celsius; SC, specific conductance in microsiemens per centimeter; DO, dissolved oxygen; SAL, salinity in parts per thousand; SD, Secchi disk depth in centimeters; Q, discharge in cubic meters per second; E, ebb flow; F, flood flow; ---, not collected]

\begin{tabular}{|c|c|c|c|c|c|c|}
\hline Station 7 (50119360) & $\mathrm{pH}$ & $\mathrm{T}$ & SC & DO & SAL & SD \\
\hline \multicolumn{7}{|c|}{ January 24, 2003 - 12:40 a.m. } \\
\hline Top & 8.2 & 26.4 & 72,000 & 5.4 & 49.6 & \\
\hline Bottom & 8.2 & 28.2 & 72,300 & 7.9 & 49.7 & 69 \\
\hline \multicolumn{7}{|c|}{ February 25, 2003 - 8:30 a.m. } \\
\hline Top & 8.1 & 25.2 & 75,900 & 6.0 & 52.6 & \\
\hline Bottom & 8.1 & 25.2 & 75,900 & 6.0 & 52.7 & 53 \\
\hline \multicolumn{7}{|c|}{ March 25, 2003 - 8:15 a.m. } \\
\hline Top & 7.9 & 28.1 & 70,000 & 4.4 & 48.3 & \\
\hline Bottom & 8.0 & 28.1 & 70,300 & 4.2 & 48.3 & 69 \\
\hline \multicolumn{7}{|c|}{ May 7, 2003 - 7:45 a.m. } \\
\hline Top & 8.4 & 27.0 & 41,500 & 7.5 & 26.6 & \\
\hline Bottom & 8.4 & 27.0 & 41,600 & 6.5 & 26.6 & 36 \\
\hline \multicolumn{7}{|c|}{ May 22, 2003 - 7:45 a.m. } \\
\hline Тор & 8.2 & 29.6 & 49,500 & 8.0 & 32.3 & \\
\hline Bottom & 8.2 & 29.6 & 49,500 & 7.1 & 32.2 & 28 \\
\hline \multicolumn{7}{|c|}{ July 15, 2003 - 8:00 a.m. } \\
\hline Тор & 8.1 & 27.8 & 63,300 & 6.8 & 42.6 & \\
\hline Bottom & 7.9 & 27.9 & 63,300 & 6.0 & 42.7 & 28 \\
\hline \multicolumn{7}{|c|}{ August 13, 2003 - 8:40 a.m. } \\
\hline Тор & 8.2 & 29.0 & 71,900 & 6.2 & 49.3 & \\
\hline Bottom & 8.3 & 29.0 & 71,900 & 6.0 & 49.3 & 30 \\
\hline \multicolumn{7}{|c|}{ September 17, 2003 - 8:15 a.m. } \\
\hline Top & 8.1 & 30.3 & 70,500 & 6.1 & 48.1 & \\
\hline Bottom & 8.1 & 31.5 & 70,500 & 5.7 & 48.2 & 46 \\
\hline \multicolumn{7}{|c|}{ October 15, 2003 - 8:12 a.m. } \\
\hline Top & 8.5 & 30.2 & 57,000 & 7.4 & 37.8 & \\
\hline Bottom & 8.5 & 30.2 & 57,000 & 6.7 & 37.8 & 46 \\
\hline \multicolumn{7}{|c|}{ November 25, 2003 - 8:25 a.m. } \\
\hline Top & 8.0 & 27.0 & 21,000 & 6.8 & 12.6 & \\
\hline Bottom & 7.4 & 29.8 & 28,400 & 1.9 & 18.5 & 48 \\
\hline \multicolumn{7}{|c|}{ December 17, 2003 - 8:05 a.m. } \\
\hline Top & 8.2 & 25.6 & 21,300 & 7.5 & 12.8 & \\
\hline Bottom & 8.3 & 25.6 & 21,300 & 7.3 & 12.8 & 36 \\
\hline \multicolumn{7}{|c|}{ January 15, 2004 - 8:17 a.m. } \\
\hline Top & 8.53 & 25.94 & 34,225 & 7.44 & 21.48 & \\
\hline Bottom & 8.52 & 25.92 & 34,201 & 7.24 & 21.44 & 46 \\
\hline \multicolumn{7}{|c|}{ February 5, 2004 - 7:45 a.m. } \\
\hline Top & 8.2 & 24.7 & 41,000 & 5.6 & 26.2 & \\
\hline Bottom & 8.2 & 24.7 & 41,000 & 5.5 & 26.2 & 25 \\
\hline \multicolumn{7}{|c|}{ March 18, 2004 - 8:20 a.m. } \\
\hline Top & 7.9 & 26.5 & 54,900 & 6.7 & 36.3 & \\
\hline Bottom & 7.9 & 26.5 & 54,900 & 6.4 & 36.3 & 38 \\
\hline
\end{tabular}


Appendix 1. On-site determination of $\mathrm{pH}$, temperature, specific conductance, dissolved oxygen, salinity, and secchi disk depth for water-quality sites sampled from February 2003 to March 2004 at the Laguna de Las Salinas, Ponce, Puerto Rico. Top values were obtained at about 15 centimeters deep and bottom values were obtained about 10 centimeters from the lagoon's bottom. Discharge data is presented for station 3 only.-Continued

[T, temperature in degrees Celsius; SC, specific conductance in microsiemens per centimeter; DO, dissolved oxygen; SAL, salinity in parts per thousand; SD, Secchi disk depth in centimeters; Q, discharge in cubic meters per second; E, ebb flow; F, flood flow; ---, not collected]

\begin{tabular}{|c|c|c|c|c|c|c|}
\hline Station 8 (50119370) & $\mathrm{pH}$ & $\mathrm{T}$ & SC & $\mathrm{DO}$ & SAL & SD \\
\hline \multicolumn{7}{|c|}{ January 24, 2003 - 10:10 a.m. } \\
\hline Top & 8.2 & 26.3 & 72,100 & 4.2 & 47.7 & \\
\hline Bottom & --- & --- & --- & --- & --- & 71 \\
\hline \multicolumn{7}{|c|}{ February 25, 2003 - 10:30 a.m. } \\
\hline Top & 8.3 & 25.7 & 74,700 & 6.0 & 51.5 & \\
\hline Bottom & 8.2 & 25.6 & 75,300 & 6.4 & 52.1 & 51 \\
\hline \multicolumn{7}{|c|}{ March 25, 2003 - 9:40 a.m. } \\
\hline Top & 8.1 & 27.6 & 66,500 & 3.6 & 45.3 & \\
\hline Bottom & 8.0 & 28.4 & 66,900 & 3.3 & 45.0 & 66 \\
\hline \multicolumn{7}{|c|}{ May 7, 2003 - 9:10 a.m. } \\
\hline Top & 8.2 & 25.9 & 32,200 & 3.8 & 20.6 & \\
\hline Bottom & 8.2 & 26.3 & 37,900 & 4.6 & 22.7 & 25 \\
\hline \multicolumn{7}{|c|}{ May 22, 2003 - 8:35 a.m. } \\
\hline Top & 8.1 & 29.2 & 49,600 & 4.4 & 32.3 & \\
\hline Bottom & 8.2 & 29.1 & 49,600 & 3.8 & 32.3 & 33 \\
\hline \multicolumn{7}{|c|}{ July 15, 2003 - 9:00 a.m. } \\
\hline Top & 7.8 & 27.1 & 61,500 & 7.5 & 41.3 & \\
\hline Bottom & 7.7 & 27.3 & 61,800 & 7.0 & 41.5 & 36 \\
\hline \multicolumn{7}{|c|}{ August 13, 2003 - 9:10 a.m. } \\
\hline Top & 8.5 & 27.3 & 66,600 & 5.9 & 42.5 & \\
\hline Bottom & 8.4 & 27.9 & 70,600 & 6.0 & 48.2 & 46 \\
\hline \multicolumn{7}{|c|}{ September 17, 2003 - 8:55 a.m. } \\
\hline Top & 8.1 & 29.5 & 67,600 & 6.7 & 46.4 & \\
\hline Bottom & 8.1 & 29.3 & 67,300 & 6.4 & 46.8 & 46 \\
\hline \multicolumn{7}{|c|}{ October 15, 2003 - 9:05 a.m. } \\
\hline Top & 8.4 & 29.9 & 56,600 & 6.8 & 37.5 & \\
\hline Bottom & 8.4 & 30.0 & 56,600 & 6.5 & 37.5 & 46 \\
\hline \multicolumn{7}{|c|}{ November 25, 2003 - 9:25 a.m. } \\
\hline Tор & 7.8 & 27.3 & 21,000 & 6.5 & 12.5 & \\
\hline Bottom & 7.8 & 27.3 & 21,000 & 6.2 & 12.6 & 61 \\
\hline \multicolumn{7}{|c|}{ December 17, 2003 - 9:00 a.m. } \\
\hline Top & 8.2 & 25.0 & 21,300 & 7.2 & 12.8 & \\
\hline Bottom & 8.2 & 25.1 & 21,300 & 7.2 & 12.8 & 30 \\
\hline \multicolumn{7}{|c|}{ January 15, 2004 - 9:18 a.m. } \\
\hline Top & 8.4 & 25.8 & 33,700 & 6.8 & 21.1 & \\
\hline Bottom & 8.4 & 25.8 & 33,700 & 6.6 & 21.1 & 46 \\
\hline \multicolumn{7}{|c|}{ February 5, 2004 - 8:50 a.m. } \\
\hline Top & 8.1 & 23.8 & 41,000 & 5.5 & 26.3 & \\
\hline Bottom & 8.1 & 23.7 & 41,100 & 5.2 & 26.3 & 25 \\
\hline \multicolumn{7}{|c|}{ March 18, 2004 - 9:15 a.m. } \\
\hline Top & 7.9 & 25.8 & 54,600 & 6.6 & 36.1 & \\
\hline Bottom & 7.9 & 26.0 & 54,600 & 6.8 & 36.1 & 41 \\
\hline
\end{tabular}


Appendix 2. May 1, 2003, diel study physical properties. Top values were obtained at about 15 centimeters in depth and bottom values were obtained about 10 centimeters from the lagoon's bottom.

[STA-ID, station identification number; T, temperature; SC, specific conductance; DO, dissolved oxygen; SAL, salinity; Q, discharge in cubic meters per second; E, ebb flow; F, flood flow; ---, not collected, N/A, not applicable]

\begin{tabular}{|c|c|c|c|c|c|c|c|c|}
\hline STA-ID & Time & Depth & $\mathrm{pH}$ & $\mathrm{T}$ & SC & DO & SAL & $Q(E / F)$ \\
\hline \multicolumn{9}{|c|}{ Station 1} \\
\hline & \multirow[t]{2}{*}{ 6:05 a.m. } & Top & 8.0 & 27.8 & 37,200 & 4.6 & 23.5 & N/A \\
\hline & & Bottom & 7.9 & 27.8 & 37,200 & 4.3 & 23.5 & N/A \\
\hline & \multirow[t]{2}{*}{ 7:09 a.m. } & Top & 8.0 & 27.8 & 37,200 & 5.6 & 23.4 & N/A \\
\hline & & Bottom & 7.9 & 27.7 & 37,200 & 4.8 & 23.5 & N/A \\
\hline & \multirow[t]{2}{*}{ 8:05 a.m. } & Тор & 7.9 & 27.9 & 37,200 & 5.1 & 23.5 & N/A \\
\hline & & Bottom & 7.8 & 27.9 & 37,200 & 4.9 & 23.5 & N/A \\
\hline & \multirow[t]{2}{*}{ 9:04 a.m. } & Тор & 7.7 & 28.1 & 37,300 & 4.6 & 23.6 & N/A \\
\hline & & Bottom & 7.5 & 28.3 & 37,400 & 3.7 & 23.6 & N/A \\
\hline & \multirow[t]{2}{*}{ 10:05 a.m. } & Тор & 7.8 & 28.9 & 37,600 & 5.3 & 23.6 & N/A \\
\hline & & Bottom & 7.6 & 29.9 & 38,800 & 5.4 & 24.5 & N/A \\
\hline & \multirow[t]{2}{*}{ 11:07 a.m. } & Top & 7.3 & 29.6 & 37,600 & 6.5 & 23.8 & N/A \\
\hline & & Bottom & 7.2 & 29.5 & 37,700 & 6.8 & 23.8 & N/A \\
\hline & \multirow[t]{2}{*}{ 12:07 p.m. } & Top & 7.1 & 30.4 & 37,600 & 7.4 & 23.7 & N/A \\
\hline & & Bottom & 7.1 & 30.2 & 37,900 & 7.6 & 23.9 & N/A \\
\hline & \multirow[t]{2}{*}{ 1:05 p.m. } & Тор & 8.0 & 30.9 & 37,800 & 7.0 & 23.9 & N/A \\
\hline & & Bottom & 7.9 & 31.0 & 37,800 & 7.1 & 23.8 & N/A \\
\hline & \multirow[t]{2}{*}{ 2:09 p.m. } & Тор & 8.0 & 31.7 & 37,900 & 7.5 & 23.9 & N/A \\
\hline & & Bottom & 7.9 & 31.3 & 38,900 & 5.2 & 23.9 & N/A \\
\hline & \multirow[t]{2}{*}{ 3:07 p.m. } & Тор & 8.1 & 32.1 & 38,000 & 8.1 & 24.0 & N/A \\
\hline & & Bottom & 8.0 & 32.1 & 38,400 & 5.1 & 24.1 & N/A \\
\hline & \multirow[t]{2}{*}{ 4:10 p.m. } & Top & 8.4 & 32.2 & 38,400 & 8.1 & 24.2 & N/A \\
\hline & & Bottom & 8.3 & 32.1 & 38,300 & 8.4 & 24.1 & N/A \\
\hline & \multirow[t]{2}{*}{ 5:05 p.m. } & Top & 8.4 & 31.6 & 38,200 & 8.3 & 24.1 & N/A \\
\hline & & Bottom & 8.3 & 31.5 & 38,200 & 8.3 & 24.1 & N/A \\
\hline & \multirow[t]{2}{*}{ 6:09 p.m. } & Top & 8.5 & 31.2 & 38,500 & 7.7 & 24.3 & N/A \\
\hline & & Bottom & 8.4 & 31.3 & 38,600 & 7.6 & 24.4 & N/A \\
\hline & \multirow[t]{2}{*}{ 7:26 p.m. } & Тор & 8.7 & 30.5 & 38,700 & 6.6 & 24.4 & N/A \\
\hline & & Bottom & 8.72 & 30.68 & 38647 & 6.51 & 24.42 & N/A \\
\hline \multicolumn{9}{|c|}{ Station 3} \\
\hline & 6:26 a.m. & Top & 7.8 & 27.8 & 54,400 & 4.5 & 35.8 & $0.05(\mathrm{~F})$ \\
\hline & 7:27 a.m. & Top & 7.8 & 27.3 & 50,300 & 4.0 & 27.1 & 0 \\
\hline & 8:24 a.m. & Тор & 7.8 & 26.9 & 38,500 & 4.4 & 24.7 & 0 \\
\hline & 9:24 a.m. & Top & 7.8 & 27.7 & 38,000 & 5.8 & 23.9 & $0.07(\mathrm{E})$ \\
\hline & 10:22 a.m. & Tор & 7.4 & 29.2 & 37,800 & 7.2 & 23.9 & $0.11(\mathrm{E})$ \\
\hline & 11:23 a.m. & Tор & 7.4 & 30.6 & 37,800 & 8.1 & 23.8 & $0.13(\mathrm{E})$ \\
\hline & 12:23 p.m. & Top & 7.4 & 31.4 & 37,900 & 8.9 & 23.9 & $0.13(\mathrm{E})$ \\
\hline & 1:22 p.m. & Tор & 8.1 & 32.2 & 38,100 & 9.0 & 24.0 & $0.13(\mathrm{E})$ \\
\hline & 2:28 p.m. & Top & 8.3 & 32.1 & 38,100 & 10.3 & 24.0 & $0.11(\mathrm{E})$ \\
\hline & 3:29 p.m. & Top & 8.3 & 32.5 & 38,100 & 10.6 & 24.1 & $0.09(\mathrm{E})$ \\
\hline & 4:30 p.m. & Top & 8.1 & 32.3 & 38,400 & 8.8 & 24.2 & 0 \\
\hline & 5:22 p.m. & Top & 8.6 & 29.6 & 49,800 & 5.4 & 34.8 & 0 \\
\hline & 6:00 p.m. & & --- & --- & --- & --- & --- & $0.12(F)$ \\
\hline & 7:00 p.m. & & --- & --- & --- & --- & --- & $0.16(\mathrm{~F})$ \\
\hline
\end{tabular}


Appendix 2. May 1, 2003, diel study physical properties. Top values were obtained at about 15 centimeters in depth and bottom values were obtained about 10 centimeters from the lagoon's bottom. - Continued

[STA-ID, station identification number; T, temperature; SC, specific conductance; DO, dissolved oxygen; SAL, salinity; Q, discharge in cubic meters per second; E, ebb flow; F, flood flow; ---, not collected, N/A, not applicable]

\begin{tabular}{|c|c|c|c|c|c|c|c|c|}
\hline \multirow{2}{*}{$\begin{array}{l}\text { STA-ID } \\
\text { Station } 4\end{array}$} & Time & Depth & $\mathrm{pH}$ & $\mathrm{T}$ & SC & DO & SAL & $0(E / F)$ \\
\hline & & & & & & & & \\
\hline & 6:11 a.m. & Top & 8.1 & 28.1 & 36,900 & 4.8 & 23.3 & N/A \\
\hline & & Bottom & 7.9 & 28.1 & 36,900 & 4.2 & 23.3 & N/A \\
\hline & 7:15 a.m. & Top & 7.9 & 27.8 & 36,900 & 3.7 & 23.3 & N/A \\
\hline & & Bottom & 7.8 & 28.0 & 37,100 & 4.1 & 23.4 & N/A \\
\hline & 8:11 a.m. & Top & 7.9 & 28.0 & 37,200 & 5.0 & 23.5 & N/A \\
\hline & & Bottom & 7.8 & 28.0 & 37,300 & 5.3 & 23.6 & N/A \\
\hline & 9:10 a.m. & Top & 7.8 & 28.0 & 37,200 & 6.0 & 23.4 & N/A \\
\hline & & Bottom & 7.7 & 28.1 & 37,100 & 5.8 & 23.4 & N/A \\
\hline & 10:11 a.m. & Top & 7.5 & 28.5 & 37,300 & 6.3 & 23.5 & N/A \\
\hline & & Bottom & 7.4 & 28.6 & 37,300 & 5.8 & 23.5 & N/A \\
\hline & 11:12 a.m. & Top & 7.5 & 28.6 & 37,200 & 7.0 & 23.5 & N/A \\
\hline & & Bottom & 7.3 & 28.8 & 37,200 & 7.1 & 23.5 & N/A \\
\hline & 12:11 p.m. & Top & 7.3 & 29.5 & 37,300 & 7.3 & 23.5 & N/A \\
\hline & & Bottom & 7.2 & 29.6 & 37,300 & 7.3 & 23.6 & N/A \\
\hline & 1:10 p.m. & Top & 8.2 & 30.0 & 37,800 & 7.7 & 23.9 & N/A \\
\hline & & Bottom & 8.2 & 30.0 & 37,800 & 7.9 & 23.9 & N/A \\
\hline & 2:14 p.m. & Top & 8.2 & 30.4 & 37,900 & 7.9 & 23.9 & N/A \\
\hline & & Bottom & 8.2 & 30.4 & 37,900 & 7.9 & 23.9 & N/A \\
\hline & 3:14 p.m. & Тор & 8.2 & 30.6 & 37,900 & 8.0 & 23.9 & N/A \\
\hline & & Bottom & 8.2 & 30.7 & 37,900 & 8.1 & 23.9 & N/A \\
\hline & 4:16 p.m. & Top & 8.5 & 30.7 & 37,800 & 7.6 & 23.8 & N/A \\
\hline & & Bottom & 7.5 & 30.8 & 37,500 & 2.5 & 23.7 & N/A \\
\hline & 5:11 p.m. & Тор & 8.5 & 30.6 & 37,800 & 7.9 & 23.8 & N/A \\
\hline & & Bottom & 8.4 & 30.6 & 37,800 & 7.9 & 23.8 & N/A \\
\hline & 6:15 p.m. & Тор & 8.6 & 30.5 & 37,900 & 7.7 & 23.9 & N/A \\
\hline & & Bottom & 8.5 & 30.3 & 37,300 & 7.4 & 23.8 & N/A \\
\hline & 7:33 p.m. & Top & 8.7 & 29.9 & 33,500 & 6.6 & 18.9 & N/A \\
\hline & & Bottom & 8.6 & 29.8 & 33,400 & 5.5 & 18.9 & N/A \\
\hline
\end{tabular}

Station 5

$\begin{array}{llllllll}\text { 6:00 a.m. } & \text { Top } & 8.0 & 27.9 & 37,200 & 6.3 & 23.5 & \text { N/A } \\ \text { 7:05 a.m. } & \text { Bottom } & 7.9 & 28.0 & 37,400 & 5.8 & 23.6 & \text { N/A } \\ & \text { Bop } & 8.1 & 27.8 & 37,300 & 6.2 & 23.5 & \text { N/A } \\ \text { 8:01 a.m. } & \text { Top } & 8.0 & 27.9 & 37,500 & 6.7 & 23.7 & \text { N/A } \\ & \text { Bottom } & 7.8 & 28.0 & 37,500 & 6.3 & 23.7 & \text { N/A } \\ \text { 9:00 a.m. } & \text { Top } & 7.9 & 28.0 & 37,600 & 6.9 & 23.8 & \text { N/A } \\ & \text { Bottom } & 7.8 & 28.1 & 37,600 & 6.9 & 23.8 & \text { N/A } \\ \text { 10:01 a.m. } & \text { Top } & 7.1 & 28.5 & 37,700 & 7.5 & 23.8 & \text { N/A } \\ & \text { Bottom } & 6.9 & 28.6 & 37,800 & 7.6 & 23.9 & \text { N/A } \\ \text { 11:01 a.m. } & \text { Top } & 7.2 & 29.1 & 37,600 & 8.0 & 23.7 & \text { N/A } \\ & \text { Bottom } & 7.1 & 29.2 & 37,500 & 7.8 & 23.7 & \text { N/A } \\ \text { 12:03 p.m. } & \text { Top } & 7.3 & 29.7 & 37,800 & 7.2 & 23.8 & \text { N/A } \\ \text { 1:02 p.m. } & \text { Bottom } & 7.2 & 29.7 & 37,700 & 7.4 & 23.8 & \text { N/A }\end{array}$


Appendix 2. May 1, 2003, diel study physical properties. Top values were obtained at about 15 centimeters in depth and bottom values were obtained about 10 centimeters from the lagoon's bottom. - Continued

[STA-ID, station identification number; T, temperature; SC, specific conductance; DO, dissolved oxygen; SAL, salinity; Q, discharge in cubic meters per second; E, ebb flow; F, flood flow; ---, not collected, N/A, not applicable]

\begin{tabular}{|c|c|c|c|c|c|c|c|c|}
\hline \multirow[t]{14}{*}{ STA-ID } & Time & Depth & $\mathrm{pH}$ & $\mathrm{T}$ & SC & DO & SAL & $\mathrm{Q}(\mathrm{E} / \mathrm{F})$ \\
\hline & & Bottom & 8.0 & 30.1 & 37,800 & 7.5 & 23.9 & N/A \\
\hline & 2:05 p.m. & Тор & 8.1 & 30.8 & 37,600 & 8.3 & 23.7 & N/A \\
\hline & & Bottom & 8.1 & 30.9 & 37,800 & 8.0 & 23.8 & N/A \\
\hline & 3:03 p.m. & Тор & 8.1 & 31.2 & 37,800 & 8.3 & 23.8 & N/A \\
\hline & & Bottom & 8.1 & 31.2 & 37,800 & 8.2 & 23.9 & N/A \\
\hline & 4:05 p.m. & Top & 8.5 & 31.1 & 38,000 & 8.0 & 23.9 & N/A \\
\hline & & Bottom & 8.4 & 31.2 & 37,900 & 8.2 & 23.9 & N/A \\
\hline & 5:00 p.m. & Top & 8.4 & 31.1 & 37,900 & 8.7 & 23.9 & N/A \\
\hline & & Bottom & 8.4 & 31.1 & 37,900 & 8.4 & 23.9 & N/A \\
\hline & 6:05 p.m. & Top & 8.4 & 31.2 & 38,100 & 8.9 & 24.1 & N/A \\
\hline & & Bottom & 8.4 & 31.1 & 38,100 & 8.1 & 24.0 & N/A \\
\hline & 7:20 p.m. & Top & 8.7 & 29.7 & 37,800 & 6.9 & 23.8 & N/A \\
\hline & & Bottom & 8.7 & 29.7 & 37,800 & 6.8 & 23.8 & N/A \\
\hline \multicolumn{9}{|l|}{ Station 6} \\
\hline & 5:55 a.m. & Top & 7.9 & 27.8 & 37,300 & 5.6 & 23.6 & N/A \\
\hline & & Bottom & 7.9 & 27.8 & 37,400 & 5.5 & 23.7 & N/A \\
\hline & 7:00 a.m. & Tор & 8.0 & 27.9 & 37,300 & 6.4 & 23.5 & N/A \\
\hline & & Bottom & 8.0 & 28.5 & 36,700 & 2.2 & 22.9 & N/A \\
\hline & 7:59 a.m. & Tор & 8.0 & 28.0 & 37,400 & 6.9 & 23.7 & N/A \\
\hline & & Bottom & 7.9 & 28.1 & 37,500 & 6.7 & 23.7 & N/A \\
\hline & 8:57 a.m. & Top & 7.7 & 28.1 & 37,400 & 7.1 & 23.6 & N/A \\
\hline & & Bottom & 7.6 & 28.2 & 37,500 & 6.9 & 23.6 & N/A \\
\hline & 9:58 a.m. & Top & 8.5 & 28.7 & 37,600 & 8.1 & 23.8 & N/A \\
\hline & & Bottom & 7.8 & 28.8 & 37,600 & 7.9 & 23.7 & N/A \\
\hline & 10:57 a.m. & Top & 7.9 & 29.3 & 37,700 & 9.5 & 23.7 & N/A \\
\hline & & Bottom & 7.7 & 29.3 & 37,600 & 9.7 & 23.7 & N/A \\
\hline & 12:00 p.m. & Top & 8.0 & 29.8 & 37,800 & 8.7 & 23.8 & N/A \\
\hline & & Bottom & 7.8 & 30.0 & 37,800 & 9.0 & 23.8 & N/A \\
\hline & 12:56 p.m. & Tор & 8.1 & 30.4 & 37,900 & 8.1 & 23.9 & N/A \\
\hline & & Bottom & 8.1 & 30.4 & 37,900 & 8.2 & 23.9 & N/A \\
\hline & 2:01 p.m. & Тор & 8.2 & 31.7 & 38,000 & 10.2 & 23.9 & N/A \\
\hline & & Bottom & 8.2 & 31.4 & 38,900 & 10.2 & 23.9 & N/A \\
\hline & 2:58 p.m. & Тор & 8.3 & 31.3 & 37,900 & 10.3 & 23.9 & N/A \\
\hline & & Bottom & 8.2 & 31.5 & 38,000 & 10.1 & 24.0 & N/A \\
\hline & 4:00 p.m. & Тор & 8.5 & 32.0 & 38,100 & 10.4 & 24.0 & N/A \\
\hline & & Bottom & 8.4 & 32.1 & 38,100 & 10.6 & 24.0 & N/A \\
\hline & 4:59 p.m. & Тор & 8.6 & 31.6 & 38,100 & 10.4 & 24.0 & N/A \\
\hline & & Bottom & 8.5 & 31.7 & 38,000 & 10.2 & 24.0 & N/A \\
\hline & 5:59 p.m. & Top & 8.5 & 31.3 & 38,200 & 9.8 & 23.9 & N/A \\
\hline & & Bottom & 8.5 & 31.4 & 38,100 & 10.8 & 23.9 & N/A \\
\hline & 7:16 p.m. & Top & 8.8 & 30.0 & 38,200 & 8.3 & 24.1 & N/A \\
\hline & & Bottom & 8.8 & 30.0 & 38,000 & 8.3 & 24.0 & N/A \\
\hline
\end{tabular}


Appendix 2. May 1, 2003, diel study physical properties. Top values were obtained at about 15 centimeters in depth and bottom values were obtained about 10 centimeters from the lagoon's bottom. - Continued

[STA-ID, station identification number; T, temperature; SC, specific conductance; DO, dissolved oxygen; SAL, salinity; Q, discharge in cubic meters per second; E, ebb flow; F, flood flow; ---, not collected, N/A, not applicable]

\begin{tabular}{|c|c|c|c|c|c|c|c|c|}
\hline \multirow{2}{*}{$\begin{array}{l}\text { STA-ID } \\
\text { Station } 8\end{array}$} & Time & Depth & $\mathrm{pH}$ & $\mathrm{T}$ & SC & DO & SAL & $\mathrm{Q}(\mathrm{E} / \mathrm{F})$ \\
\hline & & & & & & & & \\
\hline & 6:17 a.m. & Top & 7.9 & 26.8 & 36,800 & 2.2 & 23.2 & N/A \\
\hline & & Bottom & 7.8 & 26.9 & 36,700 & 2.0 & 23.2 & N/A \\
\hline & 7:22 a.m. & Top & 7.9 & 26.6 & 36,800 & 2.6 & 23.2 & N/A \\
\hline & & Bottom & 7.8 & 26.6 & 36,700 & 2.1 & 23.2 & N/A \\
\hline & 8:16 a.m. & Тор & 7.7 & 27.0 & 36,800 & 3.0 & 23.2 & N/A \\
\hline & & Bottom & 7.6 & 27.0 & 36,800 & 2.7 & 23.2 & N/A \\
\hline & 9:16 a.m. & Тор & 7.6 & 27.0 & 37,400 & 3.8 & 23.7 & N/A \\
\hline & & Bottom & 7.7 & 27.6 & 37,500 & 4.9 & 23.7 & N/A \\
\hline & 10:16 a.m. & Top & 8.0 & 28.3 & 37,500 & 6.9 & 23.7 & N/A \\
\hline & & Bottom & 7.9 & 28.4 & 37,500 & 7.1 & 23.7 & N/A \\
\hline & 11:17 a.m. & Top & 7.8 & 28.9 & 37,600 & 8.0 & 23.7 & N/A \\
\hline & & Bottom & 7.7 & 29.0 & 37,600 & 8.0 & 23.7 & N/A \\
\hline & 12:17 p.m. & Top & 7.6 & 29.5 & 37,600 & 8.8 & 23.7 & N/A \\
\hline & & Bottom & 7.0 & 29.5 & 37,600 & 8.8 & 23.7 & N/A \\
\hline & 1:16 p.m. & Top & 8.2 & 30.0 & 37,700 & 7.8 & 23.8 & N/A \\
\hline & & Bottom & 8.1 & 30.0 & 37,700 & 8.1 & 23.8 & N/A \\
\hline & 2:20 p.m. & Tор & 8.3 & 30.4 & 37,600 & 8.5 & 23.8 & N/A \\
\hline & & Bottom & 8.0 & 30.4 & 37,200 & 7.4 & 23.6 & N/A \\
\hline & 3:21 p.m. & Тор & 8.4 & 30.8 & 37,800 & 9.6 & 23.8 & N/A \\
\hline & & Bottom & 8.3 & 30.7 & 37,800 & 8.6 & 23.8 & N/A \\
\hline & 4:23 p.m. & Tор & 8.6 & 30.8 & 37,800 & 9.4 & 23.8 & N/A \\
\hline & & Bottom & 8.4 & 30.9 & 37,800 & 8.4 & 23.8 & N/A \\
\hline & 5:16 p.m. & Top & 8.6 & 30.9 & 37,800 & 8.1 & 23.8 & N/A \\
\hline & & Bottom & 8.3 & 31.1 & 37,800 & 6.0 & 23.8 & N/A \\
\hline & 6:21 p.m. & Top & 8.8 & 30.5 & 37,900 & 9.6 & 23.9 & N/A \\
\hline & & Bottom & 8.5 & 30.5 & 37,900 & 9.6 & 23.9 & N/A \\
\hline & 7:41 p.m. & Тор & 8.8 & 29.4 & 33,500 & 5.4 & 19.1 & N/A \\
\hline & & Bottom & 8.7 & 29.0 & 33,300 & 1.3 & 19.1 & N/A \\
\hline
\end{tabular}


Appendix 3. October 16, 2003, diel study physical properties. Top values were obtained at about 15 centimeters in depth and bottom values were obtained about 10 centimeters from the lagoon's bottom.

[STA-ID, station identification number; T, temperature; SC, specific conductance; DO, dissolved oxygen; SAL, salinity; Q, discharge in cubic meters per second; E, ebb flow; F, flood flow; ---, not collected]

\begin{tabular}{|c|c|c|c|c|c|c|c|c|}
\hline STA-ID & Time & Depth & $\mathrm{pH}$ & $\mathrm{T}$ & SC & DO & SAL & $0(E / F)$ \\
\hline \multicolumn{9}{|c|}{ Station 1} \\
\hline & \multirow[t]{2}{*}{ 5:47 a.m. } & Top & 8.6 & 30.1 & 57,400 & 3.9 & 38.2 & N/A \\
\hline & & Bottom & 8.6 & 30.1 & 57,600 & 3.8 & 38.2 & N/A \\
\hline & \multirow[t]{2}{*}{ 6:35 a.m. } & Top & 8.7 & 30.0 & 57,600 & 4.1 & 38.3 & N/A \\
\hline & & Bottom & 8.8 & 29.8 & 57,600 & 3.9 & 38.3 & N/A \\
\hline & \multirow[t]{2}{*}{ 7:34 a.m. } & Тор & 8.7 & 29.8 & 57,600 & 4.4 & 38.3 & N/A \\
\hline & & Bottom & 8.7 & 29.8 & 57,700 & 4.0 & 38.3 & N/A \\
\hline & \multirow[t]{2}{*}{ 8:34 a.m. } & Тор & 8.6 & 30.2 & 57,700 & 4.6 & 38.3 & N/A \\
\hline & & Bottom & 8.7 & 30.1 & 57,700 & 4.3 & 38.3 & N/A \\
\hline & \multirow[t]{2}{*}{ 9:36 a.m. } & Тор & 8.6 & 30.5 & 57,800 & 4.4 & 38.4 & N/A \\
\hline & & Bottom & 8.6 & 30.1 & 57,800 & 3.7 & 38.4 & N/A \\
\hline & \multirow[t]{2}{*}{ 10:35 a.m. } & Тор & 8.6 & 31.4 & 57,900 & 4.6 & 38.4 & N/A \\
\hline & & Bottom & 8.7 & 30.8 & 57,800 & 4.5 & 38.4 & N/A \\
\hline & \multirow[t]{2}{*}{ 11:37 a.m. } & Tор & 8.0 & 32.1 & 58,000 & 3.8 & 38.5 & N/A \\
\hline & & Bottom & 8.0 & 31.3 & 57,900 & 3.1 & 38.5 & N/A \\
\hline & \multirow[t]{2}{*}{ 12:39 p.m. } & Тор & 7.9 & 32.8 & 57,900 & 4.8 & 38.4 & N/A \\
\hline & & Bottom & 7.9 & 32.4 & 58,000 & 4.1 & 38.5 & N/A \\
\hline & \multirow[t]{2}{*}{ 1:39 p.m. } & Тор & 7.9 & 33.4 & 58,000 & 4.4 & 38.4 & N/A \\
\hline & & Bottom & 7.8 & 33.0 & 57,900 & 3.8 & 38.4 & N/A \\
\hline & \multirow[t]{2}{*}{ 2:35 p.m. } & Тор & 7.9 & 33.8 & 58,000 & 4.7 & 38.4 & N/A \\
\hline & & Bottom & 7.9 & 33.8 & 58,100 & 4.7 & 38.4 & N/A \\
\hline & \multirow[t]{2}{*}{ 3:34 p.m. } & Тор & 7.9 & 33.8 & 58,100 & 5.8 & 38.5 & N/A \\
\hline & & Bottom & 7.9 & 33.8 & 58,200 & 5.1 & 38.5 & N/A \\
\hline & \multirow[t]{2}{*}{ 4:35 p.m. } & Tор & 7.9 & 33.6 & 58,200 & 5.6 & 38.5 & N/A \\
\hline & & Bottom & 7.9 & 33.6 & 57,900 & 3.7 & 38.2 & N/A \\
\hline & \multirow[t]{2}{*}{ 5:35 p.m. } & Top & 8.0 & 33.2 & 58,200 & 4.8 & 38.6 & N/A \\
\hline & & Bottom & 8.0 & 33.3 & 58,200 & 3.6 & 38.6 & N/A \\
\hline & \multirow[t]{2}{*}{ 6:43 p.m. } & Тор & 8.0 & 32.9 & 58,200 & 3.0 & 38.6 & N/A \\
\hline & & Bottom & 8.01 & 32.87 & 58228 & 2.95 & 38.59 & N/A \\
\hline \multicolumn{9}{|c|}{ Station 3} \\
\hline & 6:08 a.m. & Top & 8.7 & 29.6 & 57,500 & 3.5 & 38.2 & $0.20(\mathrm{E})$ \\
\hline & 6:32 a.m. & Top & 8.7 & 29.6 & 57,400 & 3.6 & 38.1 & 0.22 (E) \\
\hline & 7:52 a.m. & Тор & 8.7 & 29.7 & 57,300 & 4.7 & 38.0 & $0.22(\mathrm{E})$ \\
\hline & 8:51 a.m. & Тор & 8.7 & 30.2 & 57,300 & 6.2 & 38.0 & 0.19 (E) \\
\hline & 9:53 a.m. & Top & 8.7 & 31.1 & 57,400 & 5.9 & 38.0 & $0.15(\mathrm{E})$ \\
\hline & 10:53 a.m. & Тор & 8.7 & 32.2 & 57,300 & 6.8 & 38.0 & $0.11(\mathrm{E})$ \\
\hline & 11:55 a.m. & Тор & 8.0 & 33.1 & 57,600 & 5.4 & 38.1 & 0 \\
\hline & 12:54 p.m. & Тор & 7.8 & 32.2 & 56,200 & 5.0 & 37.1 & $0.08(F)$ \\
\hline & 1:54 p.m. & Top & 7.8 & 32.5 & 54,100 & 5.0 & 33.5 & $0.10(\mathrm{~F})$ \\
\hline & 2:50 p.m. & Тор & 7.9 & 32.4 & 53,700 & 5.4 & 35.2 & $0.16(F)$ \\
\hline & 3:41 p.m. & Тор & 7.8 & 32.1 & 53,600 & 5.1 & 35.2 & $0.17(\mathrm{~F})$ \\
\hline & 4:48 p.m. & Top & 7.8 & 31.6 & 53,400 & 4.8 & 35.1 & $0.16(F)$ \\
\hline & 5:50 p.m. & Top & 7.8 & 31.0 & 53,400 & 3.0 & 35.0 & $0.11(F)$ \\
\hline & 7:01 p.m. & Top & 7.8 & 30.8 & 53,700 & 2.1 & 35.3 & 0 \\
\hline
\end{tabular}


Appendix 3. October 16, 2003, diel study physical properties. Top values were obtained at about 15 centimeters in depth and bottom values were obtained about 10 centimeters from the lagoon's bottom.-Continued

[STA-ID, station identification number; T, temperature; SC, specific conductance; DO, dissolved oxygen; SAL, salinity; Q, discharge in cubic meters per second; E, ebb flow; F, flood flow; ---, not collected]

\begin{tabular}{|c|c|c|c|c|c|c|c|c|}
\hline STA-ID & Time & Depth & $\mathrm{pH}$ & $T$ & SC & $\mathrm{DO}$ & SAL & $0(E / F)$ \\
\hline \multicolumn{9}{|c|}{ Station 4} \\
\hline & \multirow[t]{2}{*}{ 5:42 a.m. } & Top & 8.6 & 30.6 & 57,000 & 4.7 & 37.8 & N/A \\
\hline & & Bottom & 8.6 & 30.6 & 57,000 & 4.7 & 37.7 & N/A \\
\hline & \multirow[t]{2}{*}{ 6:31 a.m. } & Тор & 8.6 & 30.6 & 57,300 & 4.4 & 38.0 & N/A \\
\hline & & Bottom & 8.7 & 30.6 & 57,200 & 4.3 & 37.9 & N/A \\
\hline & \multirow[t]{2}{*}{ 7:31 a.m. } & Tор & 8.6 & 30.5 & 57,400 & 5.1 & 38.1 & N/A \\
\hline & & Bottom & 8.6 & 30.6 & 57,400 & 4.8 & 38.1 & N/A \\
\hline & \multirow[t]{2}{*}{ 8:31 a.m. } & Top & 8.7 & 30.5 & 57,500 & 5.5 & 38.1 & N/A \\
\hline & & Bottom & 8.6 & 30.6 & 57,500 & 5.1 & 38.1 & N/A \\
\hline & \multirow[t]{2}{*}{ 9:32 a.m. } & Top & 8.8 & 30.8 & 57,500 & 6.2 & 38.2 & N/A \\
\hline & & Bottom & 8.7 & 30.8 & 57,600 & 6.1 & 38.2 & N/A \\
\hline & \multirow[t]{2}{*}{ 10:31 a.m. } & Top & 8.8 & 31.2 & 57,600 & 6.3 & 38.2 & N/A \\
\hline & & Bottom & 8.8 & 31.2 & 57,500 & 5.9 & 38.2 & N/A \\
\hline & \multirow[t]{2}{*}{ 11:34 a.m. } & Тор & 8.1 & 31.8 & 57,800 & 4.9 & 38.3 & N/A \\
\hline & & Bottom & 8.1 & 31.6 & 57,800 & 4.5 & 38.3 & N/A \\
\hline & \multirow[t]{2}{*}{ 12:36 p.m. } & Тор & 8.0 & 31.9 & 57,600 & 4.9 & 38.2 & N/A \\
\hline & & Bottom & 8.0 & 32.4 & 57,600 & 4.7 & 38.1 & N/A \\
\hline & \multirow[t]{2}{*}{ 1:35 p.m. } & Тор & 8.0 & 32.4 & 57,700 & 4.9 & 38.2 & N/A \\
\hline & & Bottom & 8.0 & 32.5 & 57,700 & 4.8 & 38.2 & N/A \\
\hline & \multirow[t]{2}{*}{ 2:32 p.m. } & Top & 8.1 & 32.6 & 57,500 & 5.8 & 38.1 & N/A \\
\hline & & Bottom & 6.8 & 32.9 & 55,500 & 2.3 & 36.6 & N/A \\
\hline & \multirow[t]{2}{*}{ 3:32 p.m. } & Тор & 8.0 & 32.7 & 57,700 & 6.5 & 38.2 & N/A \\
\hline & & Bottom & 8.0 & 32.8 & 57,600 & 5.3 & 38.2 & N/A \\
\hline & \multirow[t]{2}{*}{ 4:32 p.m. } & Тор & 8.0 & 32.6 & 57,700 & 6.4 & 38.2 & N/A \\
\hline & & Bottom & 8.0 & 32.7 & 57,700 & 5.7 & 38.2 & N/A \\
\hline & \multirow[t]{2}{*}{ 5:29 p.m. } & Top & 8.1 & 32.5 & 57,800 & 6.1 & 38.3 & N/A \\
\hline & & Bottom & 8.1 & 32.6 & 57,800 & 5.2 & 38.3 & N/A \\
\hline & \multirow[t]{2}{*}{ 6:40 p.m. } & Top & 8.1 & 32.5 & 57,700 & 3.5 & 38.3 & N/A \\
\hline & & Bottom & 8.0 & 32.8 & 58,000 & 3.3 & 38.4 & N/A \\
\hline \multicolumn{9}{|c|}{ Station 5} \\
\hline & \multirow[t]{2}{*}{ 5:54 a.m. } & Тор & 8.6 & 30.4 & 57,000 & 4.6 & 37.7 & N/A \\
\hline & & Bottom & 8.3 & 32.6 & 58,500 & 0.7 & 39.6 & N/A \\
\hline & \multirow[t]{2}{*}{ 6:39 a.m. } & Top & 8.8 & 30.4 & 57,000 & 4.8 & 37.7 & N/A \\
\hline & & Bottom & 8.6 & 31.8 & 58,000 & 1.9 & 38.5 & N/A \\
\hline & \multirow[t]{2}{*}{ 7:39 a.m. } & Тор & 8.7 & 30.3 & 57,000 & 4.8 & 37.8 & N/A \\
\hline & & Bottom & 8.5 & 32.0 & 59,200 & 1.6 & 39.3 & N/A \\
\hline & \multirow[t]{2}{*}{ 8:38 a.m. } & Top & 8.7 & 30.5 & 57,200 & 4.7 & 37.9 & N/A \\
\hline & & Bottom & 8.5 & 31.4 & 57,600 & 1.6 & 37.8 & N/A \\
\hline & \multirow[t]{2}{*}{ 9:41 a.m. } & Top & 8.7 & 30.7 & 57,300 & 4.8 & 38.0 & N/A \\
\hline & & Bottom & 8.0 & 31.0 & 57,200 & 0.5 & 37.8 & N/A \\
\hline & \multirow[t]{2}{*}{ 10:40 a.m. } & Top & 8.7 & 31.3 & 57,400 & 4.7 & 38.0 & N/A \\
\hline & & Bottom & 8.6 & 31.5 & 57,400 & 3.5 & 38.0 & N/A \\
\hline & 11:42 a.m. & Тор & 8.0 & 32.0 & 57,400 & 4.1 & 38.1 & N/A \\
\hline & & Bottom & 8.0 & 32.1 & 57,400 & 3.7 & 38.0 & N/A \\
\hline & 12:43 p.m. & Top & 8.0 & 32.7 & 57,700 & 5.1 & 38.2 & N/A \\
\hline
\end{tabular}


Appendix 3. October 16, 2003, diel study physical properties. Top values were obtained at about 15 centimeters in depth and bottom values were obtained about 10 centimeters from the lagoon's bottom.-Continued

[STA-ID, station identification number; T, temperature; SC, specific conductance; DO, dissolved oxygen; SAL, salinity; Q, discharge in cubic meters per second; E, ebb flow; F, flood flow; ---, not collected]

\begin{tabular}{|c|c|c|c|c|c|c|c|c|}
\hline \multirow[t]{14}{*}{ STA-ID } & Time & Depth & $\mathrm{pH}$ & $\mathrm{T}$ & SC & DO & SAL & $\mathrm{Q}(\mathrm{E} / \mathrm{F})$ \\
\hline & & Bottom & 6.7 & 33.0 & 55,300 & 2.7 & 36.4 & N/A \\
\hline & 1:43 p.m. & Top & 7.9 & 33.9 & 58,000 & 3.8 & 38.4 & N/A \\
\hline & & Bottom & 7.8 & 33.6 & 57,800 & 3.8 & 38.2 & N/A \\
\hline & 2:40 p.m. & Top & 7.8 & 34.1 & 57,200 & 3.8 & 37.8 & N/A \\
\hline & & Bottom & 7.8 & 34.0 & 58,300 & 3.7 & 38.6 & N/A \\
\hline & 3:39 p.m. & Top & 7.8 & 34.1 & 57,800 & 3.7 & 38.2 & N/A \\
\hline & & Bottom & 7.7 & 34.2 & 58,400 & 3.6 & 38.5 & N/A \\
\hline & 4:38 p.m. & Тор & 7.8 & 33.6 & 57,500 & 3.8 & 38.0 & N/A \\
\hline & & Bottom & 7.8 & 33.6 & 58,300 & 2.5 & 38.6 & N/A \\
\hline & 5:39 p.m. & Top & 8.0 & 33.2 & 58,100 & 3.2 & 38.3 & N/A \\
\hline & & Bottom & 8.0 & 33.3 & 58,200 & 3.0 & 38.6 & N/A \\
\hline & 6:48 p.m. & Top & 7.9 & 33.2 & 58,100 & 2.7 & 38.5 & N/A \\
\hline & & Bottom & 8.0 & 32.9 & 58,100 & 2.6 & 38.5 & N/A \\
\hline \multicolumn{9}{|c|}{ Station 6} \\
\hline & 6:04 a.m. & Top & 8.7 & 30.4 & 57,300 & 4.4 & 38.1 & N/A \\
\hline & & Bottom & 8.7 & 30.4 & 57,400 & 4.0 & 38.1 & N/A \\
\hline & 6:47 a.m. & Top & 8.7 & 30.1 & 57,300 & 4.8 & 38.0 & N/A \\
\hline & & Bottom & 8.7 & 30.1 & 57,300 & 4.2 & 38.0 & N/A \\
\hline & 7:45 a.m. & Top & 8.7 & 30.1 & 57,200 & 5.1 & 37.9 & N/A \\
\hline & & Bottom & 8.7 & 30.0 & 57,300 & 4.3 & 38.0 & N/A \\
\hline & 8:46 a.m. & Top & 8.7 & 30.3 & 57,200 & 5.7 & 37.9 & N/A \\
\hline & & Bottom & 8.7 & 30.3 & 57,200 & 5.6 & 37.9 & N/A \\
\hline & 9:48 a.m. & Top & 8.7 & 30.6 & 57,200 & 4.8 & 37.9 & N/A \\
\hline & & Bottom & 8.7 & 30.6 & 57,200 & 4.6 & 37.9 & N/A \\
\hline & 10:48 a.m. & Top & 8.7 & 31.1 & 57,300 & 6.1 & 37.9 & N/A \\
\hline & & Bottom & 8.7 & 31.2 & 57,300 & 6.0 & 37.9 & N/A \\
\hline & 11:49 a.m. & Top & 8.1 & 31.8 & 57,300 & 5.1 & 38.0 & N/A \\
\hline & & Bottom & 8.1 & 31.8 & 57,400 & 5.0 & 38.0 & N/A \\
\hline & 12:50 p.m. & Top & 8.0 & 32.4 & 57,400 & 5.5 & 38.0 & N/A \\
\hline & & Bottom & 8.0 & 32.4 & 57,400 & 5.5 & 38.0 & N/A \\
\hline & 1:49 p.m. & Top & 8.0 & 33.0 & 57,500 & 5.3 & 38.0 & N/A \\
\hline & & Bottom & 8.0 & 33.0 & 57,500 & 4.9 & 38.0 & N/A \\
\hline & 2:45 p.m. & Top & 8.0 & 33.4 & 57,700 & 5.8 & 38.1 & N/A \\
\hline & & Bottom & 8.0 & 33.4 & 57,600 & 5.9 & 38.1 & N/A \\
\hline & 3:44 p.m. & Тор & 8.0 & 33.4 & 57,700 & 6.1 & 38.2 & N/A \\
\hline & & Bottom & 8.0 & 33.4 & 57,700 & 5.8 & 38.2 & N/A \\
\hline & 4:44 p.m. & Тор & 8.0 & 33.1 & 57,700 & 5.8 & 38.2 & N/A \\
\hline & & Bottom & 8.0 & 33.1 & 57,700 & 5.2 & 38.2 & N/A \\
\hline & 5:45 p.m. & Тор & 8.1 & 32.5 & 57,700 & 4.0 & 37.8 & N/A \\
\hline & & Bottom & 8.1 & 32.8 & 57,700 & 3.8 & 38.2 & N/A \\
\hline & 6:56 p.m. & Тор & 8.0 & 32.1 & 56,900 & 2.6 & 37.6 & N/A \\
\hline & & Bottom & 8.0 & 32.5 & 57,500 & 2.2 & 38.0 & N/A \\
\hline
\end{tabular}


Appendix 3. October 16, 2003, diel study physical properties. Top values were obtained at about 15 centimeters in depth and bottom values were obtained about 10 centimeters from the lagoon's bottom.-Continued

[STA-ID, station identification number; T, temperature; SC, specific conductance; DO, dissolved oxygen; SAL, salinity; Q, discharge in cubic meters per second; E, ebb flow; F, flood flow; ---, not collected]

\begin{tabular}{|c|c|c|c|c|c|c|c|c|}
\hline \multirow{2}{*}{$\begin{array}{l}\text { STA-ID } \\
\text { Station } 8\end{array}$} & \multirow[t]{2}{*}{ Time } & \multirow[t]{2}{*}{ Depth } & \multirow[t]{2}{*}{$\mathrm{pH}$} & \multirow[t]{2}{*}{$\mathrm{T}$} & \multirow[t]{2}{*}{ SC } & \multirow[t]{2}{*}{ DO } & \multirow[t]{2}{*}{ SAL } & \multirow[t]{2}{*}{$0(\mathrm{E} / \mathrm{F}$} \\
\hline & & & & & & & & \\
\hline & 6:00 a.m. & Top & 8.7 & 29.7 & 57,000 & 3.3 & 37.8 & N/A \\
\hline & & Bottom & 8.7 & 29.6 & 57,100 & 3.1 & 37.8 & N/A \\
\hline & 6:42 a.m. & Тор & 8.8 & 29.5 & 57,200 & 3.5 & 37.9 & N/A \\
\hline & & Bottom & 8.8 & 29.1 & 56,800 & 2.8 & 37.7 & N/A \\
\hline & 7:42 a.m. & Тор & 8.7 & 29.5 & 57,800 & 3.7 & 37.9 & N/A \\
\hline & & Bottom & 8.7 & 29.4 & 57,000 & 3.4 & 37.8 & N/A \\
\hline & 8:47 a.m. & Top & 8.7 & 29.7 & 57,100 & 4.4 & 37.9 & N/A \\
\hline & & Bottom & 8.7 & 29.7 & 57,100 & 4.2 & 37.9 & N/A \\
\hline & 9:45 a.m. & Top & 8.7 & 30.1 & 57,200 & 3.8 & 37.9 & N/A \\
\hline & & Bottom & 8.7 & 30.1 & 57,200 & 4.1 & 37.9 & N/A \\
\hline & 10:44 a.m. & Top & 8.7 & 31.0 & 57,700 & 5.1 & 38.2 & N/A \\
\hline & & Bottom & 8.7 & 30.8 & 57,200 & 5.1 & 38.0 & N/A \\
\hline & 11:46 a.m. & Tор & 8.1 & 31.6 & 57,600 & 4.5 & 38.2 & N/A \\
\hline & & Bottom & 8.1 & 31.6 & 57,500 & 4.5 & 38.2 & N/A \\
\hline & 12:47 p.m. & Tор & 8.0 & 32.2 & 57,600 & 4.5 & 38.1 & N/A \\
\hline & & Bottom & 8.00 & 32.2 & 57,500 & 4.8 & 38.1 & N/A \\
\hline & 1:46 p.m. & Top & 8.0 & 32.6 & 57,600 & 4.8 & 38.1 & N/A \\
\hline & & Bottom & 8.0 & 32.6 & 57,600 & 4.8 & 38.1 & N/A \\
\hline & 2:43 p.m. & Top & 8.0 & 33.1 & 57,700 & 5.1 & 38.1 & N/A \\
\hline & & Bottom & 8.0 & 33.3 & 57,500 & 5.1 & 38.1 & N/A \\
\hline & 3:41 p.m. & Top & 8.0 & 32.8 & 57,600 & 5.8 & 38.2 & N/A \\
\hline & & Bottom & 8.0 & 32.8 & 57,600 & 5.6 & 38.2 & N/A \\
\hline & 4:41 p.m. & Top & 8.3 & 32.7 & 57,700 & 5.3 & 38.2 & N/A \\
\hline & & Bottom & 8.0 & 32.7 & 57,700 & 5.4 & 38.2 & N/A \\
\hline & 5:42 p.m. & Top & 8.1 & 32.6 & 57,800 & 4.1 & 38.3 & N/A \\
\hline & & Bottom & 8.1 & 32.6 & 57,800 & 3.8 & 38.3 & N/A \\
\hline & $6: 52$ & Top & 8.0 & 32.2 & 57,800 & 2.9 & 38.3 & N/A \\
\hline & & Bottom & 8.1 & 32.4 & 57,800 & 2.6 & 38.3 & N/A \\
\hline
\end{tabular}


Appendix 4. Fecal bacteria counts from February 2003 to March 2004.

[col/100 mL, colonies per 100 milliliters; ---, not collected; <, less than; >, greater than]

February 25, 2003

\begin{tabular}{|c|c|c|}
\hline Station number or name & Fecal coliform col/100 mL & E. coli col/100 mL \\
\hline 3 & --- & --- \\
\hline 4 & 0 & 630 \\
\hline 8 & --- & --- \\
\hline Supplemental station & --- & --- \\
\hline \multicolumn{3}{|l|}{ March 25, 200} \\
\hline Station number or name & Fecal coliform col/100 mL & E. coli col/100 mL \\
\hline 3 & 9 & 35 \\
\hline 4 & 0 & 7 \\
\hline 8 & 3 & 124 \\
\hline Supplemental station & 2 & 123 \\
\hline \multicolumn{3}{|l|}{ May 7, 2003} \\
\hline Station number or name & Fecal coliform col/100 mL & E. coli col/100 mL \\
\hline 3 & 5 & 9 \\
\hline 4 & $<2$ & 9 \\
\hline 8 & $>600$ & $>600$ \\
\hline Supplemental station & 62 & 54 \\
\hline \multicolumn{3}{|l|}{ May 22, 2003} \\
\hline Station number or name & Fecal coliform col/100 mL & E. coli col/100 mL \\
\hline 3 & $<2$ & 12 \\
\hline 4 & $<2$ & 11 \\
\hline 8 & $<4$ & 17 \\
\hline Supplemental station & $<2$ & $<2$ \\
\hline \multicolumn{3}{|l|}{ July 15, 2003} \\
\hline Station number or name & Fecal coliform col/100 mL & E. coli col/100 mL \\
\hline 3 & 8 & 8 \\
\hline 4 & $<2$ & $<2$ \\
\hline 8 & $<4$ & $<4$ \\
\hline Supplemental station & 4 & 8 \\
\hline \multicolumn{3}{|l|}{ August 13, 2003} \\
\hline Station number or name & Fecal coliform col/100 mL & E. coli col./100 mL \\
\hline 3 & 4 & 4 \\
\hline 4 & $<4$ & $<4$ \\
\hline 8 & 4 & $<4$ \\
\hline Supplemental station & $<4$ & 9 \\
\hline \multicolumn{3}{|l|}{ September 17, 2003} \\
\hline Station number or name & Fecal coliform col./100 mL & E. coli col/100 mL \\
\hline 3 & 4 & 8 \\
\hline 4 & $<2$ & $<2$ \\
\hline 8 & 3 & 4 \\
\hline Supplemental station & 2 & 4 \\
\hline
\end{tabular}


Appendix 4. Fecal bacteria counts from February 2003 to March 2004.-Continued

[col/100 mL, colonies per 100 milliliters; ---, not collected; <, less than; >, greater than]

October 15, 2003

Station number or name

3

4

8

Supplemental station

November 25, 2003

Station number or name

3

4

8

Supplemental station

December 17, 2003

Station number or name 3

4

8

Supplemental station

January 15, 2004

Station number or name

3

4

8

Supplemental station

February 5, 2004

Station number or name

3

4

8

Supplemental station

March 18, 2004

Station number or name

3

4

8

Supplemental station

$\begin{array}{ll}\text { Fecal coliform col } 100 \mathrm{~mL} & \text { E. coli col } / 100 \mathrm{~mL} \\ 2 & 2 \\ <2 & 4 \\ 2 & 7 \\ <2 & 4\end{array}$

Fecal coliform col/100 mL $\quad$ E. coli col $/ 100 \mathrm{~mL}$

9

44

$13 \quad 9$

822

Fecal coliform col $/ 100 \mathrm{~mL} \quad$ E. coli col $/ 100 \mathrm{~mL}$

$36 \quad 23$

$8-5$

$12 \quad 13$

$8 \quad 40$

Fecal coliform col/100 mL E. coli col/100 mL

203

4 0

$12 \quad 19$

$44 \quad 63$

Fecal coliform col/100 mL $\quad$ E. coli col $/ 100 \mathrm{~mL}$

$48 \quad 34$

$4 \quad 2$

$18-18$

$4 \quad 5$

Fecal coliform col $/ 100 \mathrm{~mL} \quad$ E. coli col $/ 100 \mathrm{~mL}$

$6 \quad 9$

$<2 \quad<2$

$<2 \quad<2$

$<2 \quad 2$


U.S. Geological Survey

Caribbean Water Science Center

GSA Center, Suite 400-15

651 Federal Drive

Guaynabo, Puerto Rico 00965-5703 